\title{
OD ZEMLJE DO KRALJEVSTVA MJESTO BOSNE U STRUKTURI ARCHIREGNUMA
}

Mladen ANČIĆ

Sveučilište u Zadru

Odjel za povijest

Rudera Boškovića 5

HR - 23000 Zadar

mancic55@hotmail.com
UDK $94(497.6) " 11 / 14 "$ $32(497.6) " 11 / 14 "$ Izvorni znanstveni rad Primljeno: 16. srpnja 2015 Prihvaćeno: 3. kolovoza 2015.

Sažetak

Polazeći od okolnosti izdavanja isprave bosanskoga kralja Stjepana Tomaša o uzimanju pod zaštitu udovice Ivaniša Blagajskog 1446., autor raspravlja o sklopu odnosa Bosanske Banovine (Kraljevstva) s Ugarsko-Hrvatskim Kraljevstvom. Taj sklop odnosa i način na koji je on $s$ vremenom konceptualiziran kod samih sudionika i uobličen u "slike u glavama" autor objašnjava u kontekstu političkoga sustava koji se u literaturi naziva Archiregnum Hungaricum. Pri tomu posebnu pozornost poklanja okolnostima pod kojima su ti odnosi uspostavljeni u drugoj četvrti 12. stoljeća. Autor upozorava na važnost pojma "zemlja" (terra, land) te razmatra proces okrupnjavanja političkih tvorbi kroz koncentraciju moći u dinastičkome središtu. U posljednjem dijelu rasprave, na temelju detaljne raščlambe zbivanja iz 1435. i 1436. godine, autor razmatra misaone sheme iz kojih proizlazi praktično djelovanje političkih aktera.

Ključne riječi: Bosna, Ugarsko-Hrvatsko Kraljevstvo, dinastička država, politički koncepti. 
Kancelarija bosanskoga kralja Stjepana Tomaša izdala je 25. svibnja 1446. svečano ispisani dokument (zavjernica) kojim kralj formalno uzima pod zaštitu Doroteju, udovicu kneza Ivaniša Blagajskoga, i njezina sina $\mathrm{Mi}$ klouša. Destinatarima je dokument očigledno bio potreban i važan te je pohranjen u obiteljski arhiv, u kojem je čuvan i sačuvan (kroza sve susljedne selidbe) sve dok taj obiteljski arhiv nije postao arhivska zbirka koja je u 19. stoljeću dospjela u Mađarski državni arhiv (Magyar orszagos leveltar - dalje MOL). Krajem 19. stoljeća dokumenti koji su preostali iz izvornoga obiteljskog arhiva knezova Blagajskih (jasno se može razabrati kako se zapravo radi o "ostatcima ostataka"), a koji su tvorili arhivsku zbirku, tiskani su u posebnome izdanju, no isprava o uzimanju u zaštitu Ivanišove udovice i njezina sina (transkribirana s onoga istog izvornika iz arhiva Blagajskih) stoji povjesničarima na raspolaganju mnogo dulje. ${ }^{1}$ Unatoč dakle relativno lakoj dostupnosti, dokument nije pobuđivao interes modernih povjesničara jer je okolnosti njegova postanka teško razabrati, pa je samim time i on teško razumljiv - što je značio i zašto je bio potreban destinatarima (Doroteji i njezinu sinu Mikloušu/Nikoli) podjednako je zagonetka kao i pitanje zašto ga je u toj formi i u tome trenutku izdala kancelarija bosanskoga kralja te što je stvarno prethodilo izdavanju toga dokumenta. Potraga za odgovorima na ta teška pitanja postaje međutim znatno lakša uzme li se u obzir činjenica da je sačuvana, ali ne u sklopu ostataka obiteljskoga arhiva Blagajskih i oporuka kneza Ivaniša Blagajskoga, napisana u Čazmi točno četiri godine prije izdavanja isprave o kraljevskoj zaštiti. ${ }^{2}$

* Zahvaljujem Uredništvu Hercegovine te anonimnim recenzentima na dragocjenim savjetima (od kojih neke, vjerojatno na svoju štetu, nisam prihvatio). Posebno zahvaljujem kolegici Nelli Lonzi na čitanju teksta i oštroumnim primjedbama koje su uvelike doprinijele njegovoj kvaliteti.

1 S obzirom da povijest arhiva knezova Blagajskih ovdje nije od interesa, jednostavno ću čitatelja uputiti na tiskanu zbirku dokumenata koja tvori današnju arhivsku zbirku u sklopu Mađarskoga državnog arhiva. Riječ je dakle o djelu: Lajos Thallóczy - SAMU Barabás (prir.), Codex diplomaticus comitum de Blagay (dalje: Codex Blagay), Magyar Tudományos Akadémia (dalje: MTA), Budapest, 1897. Dokument što ga je izdala kancelarija kralja Stjepana Tomaša 25. svibnja 1446. tiskan je na stranicama 342-344, pod brojem CLXXXIV. Kako izgleda može se jasno vidjeti na fotografiji dostupnoj na internetskoj stranici Mađarskoga državnog arhiva (http://mol.arcanum.hu/dldf/) pod brojem 66589. Na toj su internetskoj stranici inače dostupni svi dokumenti koji tvore zbirku što se odnosi na razdoblje prije 1526. godine (neovisno o tomu je li riječ o dokumentima koji su fizički u posjedu toga arhiva, ili je riječ o fotografijama dokumenata koji se nalaze u različitim arhivima od Španjolske do Poljske), pa ću te dokumente nadalje citirati skraćenicom MOL i brojem pod kojim se vode u arhivu (pod tim su brojevima dokumenti i dostupni za internetski pregled). No, i prije tiskanja u zbirci dokumenata arhiva Blagajskih, isprava kralja Stjepana Tomaša objavljivana je najmanje četiri puta (između ostaloga u zbirkama dokumenata koje su priredili Franz Miklosich, Ivan Kukuljević Sakcinski te Đuro Šurmin), tako da je ovo bilo peto tiskano izdanje - za povijest izdavanja dokumenta usp. Đuro Surmin (prir.), Hrvatski spomenici, Zagreb, 1898., str. 167, bilješka uz dokument br. 94 , koji zapravo predstavlja izdanje isprave od 25 . svibnja 1446. s neznatnim razlikama u čitanju u odnosu na verziju objavljenu u Codexu.

2 Oporuka, sastavljena 22. svibnja 1442. u Čazmi, sačuvana je u dva primjerka, a oba se nalaze u Arhivu zagrebačkoga kaptola, no u ovoj sam se prigodi koristio fotografijama 
Jedna od odredbi te oporuke eksplicitno povjerava "skrb i zaštitu" nad ženom i sinom testatora, u slučaju njegove smrti, "gospodi kralju Bosne, knezovima Celjskim, Lovri palatinu i banu Matku". S time već postaje mnogo jasnije kako je i zašto došlo do toga da kancelarija bosanskoga kralja Stjepana Tomaša izda zavjernicu od 25. svibnja 1446. No, spominjanje kralja Bosne u istome kontekstu s "knezovima Celjskim" (a riječ je 1442. godine bila o Fridriku II. i Ulriku II. Celjskima, velikašima Ugarsko-Hrvatskoga Kraljevstva ${ }^{3}$ i Svetoga Rimskog Carstva), "Lovrom palatinom" (tu je, pak, riječ o Lovri Iločkom, jednom od najutjecajnijih velikaša istoga Kraljevstva, koji je $\mathrm{u}$ tome trenutku obnašao jednu od najviših časti poslije samoga kralja, onu palatinsku) te "banom Matkom" (iza toga izričaja stoji Matko Talovac, tadašnji ban "Dalmacije, Hrvatske i cijeloga Slovinja", također u to doba jedan od najmoćnijih i najutjecaj- nijih velikaša), prigoda je u kojoj ću još jednom razmotriti poziciju bosanskoga kralja i njegov odnos spram ugarsko-hrvatskoga vladara, odnosno prigoda u kojoj se još jednom mogu pozabaviti pitanjima kojima sam se u posljednjih dvadesetak godina najizravnije bavio u četiri navrata. ${ }^{4}$ Pokušat ću utvrditi okolnosti i značenje sklopa odnosa uspostavljenih u prvoj polovici 12. stoljeća, s time u svezi razmotriti razvojnu putanju oblika društvene organizacije vlasti na određenome teritoriju te se posebice osvrnuti na odnose nakon uspostave kraljevske vlasti u Bosni 1378. godine. Prije toga, međutim, ponukan činjenicom da je to jedno od rijetkih djela u kojem se uopće spominje zavjernica o zaštiti Doroteje i njezina sina, osvrnut ću se na jedno (a zapravo bi se moglo reći i jedino) djelo čiji se autor u međuvremenu nakon nastanka spomenutih tekstova pokušao baviti problemom odnosa bosanskoga kralja i ugarsko-hrvatskih vladara.

kojima raspolaže Mađarski državni arhiv. Prvi primjerak oporuke sačuvan je u formi autentičnoga (ovjerenoga) prijepisa zagrebačkoga kaptola, izdanog 29. kolovoza 1469. po zahtjevu "časnoga muža gospodina Jurja, župnika crkve sv. Nikole u opidumu Jastrebarsko", a u ime Martina Frankopana i njegove žene Doroteje, udovice kneza Ivana Blagajskoga (MOL DF 255574. Transkript cijeloga toga dokumenta donosim ovdje kao Prilog IV.). Drugi, mlađi, primjerak oporuke zapravo je neovjereni prijepis, po svemu sudeći iz 16. stoljeća, za kojega se ne zna kako je i zašto nastao.

3 Naziv "Ugarsko-Hrvatsko Kraljevstvo" odavno je, barem u hrvatskoj historiografiji, prihvaćena konvencija, no takav kakav jest on ne odgovara u potpunosti kao oznaka za složenu političku tvorbu koju je na internacionalnoj razini najprikladnije označiti kao Archiregnum Hungaricum (taj će, pak, pojam biti detaljnije objašnjen dalje u tekstu). Kako bi stalno ponavljanje toga pojma s jedne strane, a s druge strane uvođenje novoga naziva otežalo čitanje teksta, nastavit ću koristiti već uobičajeni naziv "Ugarsko-Hrvatsko Kraljevstvo" sa svim izvedenicama, uz posebnu pripomenu kako ga nadalje koristim upravo kao sinonim za Archiregnum Hungaricum.

4 Usp. Mladen AnčIć, Putanja klatna. Ugarsko-hrvatsko kraljevstvo i Bosna u XIV. stolje$c ́$, Zavod za povijesne znanosti HAZU - ZIRAL, Zadar - Mostar, 1997.; Isti, Na rubu Zapada. Tri stoljeća srednjovjekovne Bosne, Hrvatski institut za povijest - Dom i svijet, Zagreb, 2001., str. 12-28; Isti, "Bilinopoljska abjuracija u suvremenom europskom kontekstu", u: Prilozi, 32, Sarajevo, 2003.; Istı, "Bosanska banovina i njezino okruženje u prvoj polovici 13. stoljeća", u: Franjo Šanjex (ur.), Fenomen "krstjani" u srednjovjekovnoj Bosni i Humu, Hrvatski institut za povijest, Sarajevo - Zagreb, 2005. 
Riječ je o djelu Dubravka Lovrenovića, koje se pojavilo još 2006. godine, na koje sam se inače tek nuzgredno osvrnuo u jednom ranijem tekstu, ostavljajući detaljniju razradbu tada iznesenih primjedbi za neku drugu prigodu. ${ }^{5}$ Lovrenovićevo je djelo, inače, nakon pojave doživjelo nekoliko pohvalnih prikaza $^{6}$ te se u historiografiji, vjerojatno slijedom logike fizičke impozantnosti, luksuzne opreme i dojma ozbiljnosti (koji proizlazi iz pogleda na golemi kritički aparat i bibliografiju) počelo i citirati kao relevantno i autoritativno, unatoč svim nedostatcima o kojima će dalje biti riječi. Vjerojatno će biti čitatelja koje će iznenaditi nešto oštriji ton moga prikaza, no on je posljedica onih vrlo pozitivnih reakcija koje držim prilično neumjesnima, poglavito stoga što su autori dva od tri prikaza afilirani istoj instituciji za koju je vezan i sam D. Lovrenović, a to je Filozofski fakultet Univerziteta u Sarajevu.

Pozivajući se dakako na tiskano izdanje zavjernice kralja Stjepana Tomaša od 25. svibnja 1446., D. Lovrenović (na jedinome mjestu u svome fizički impozantnom djelu gdje se na nju osvrće) iznosi nekoliko tvrdnji koje bi se mogle smatrati tipičnim za cijeli njegov pristup povijesnim vrelima i uopće njegovo shvaćanje načina rada povjesničara:

"Uzimajući ih u zaštitu (sc. Doroteju i Nikolu - op. M.A.) ... (i) ... postavljajući se u ulogu njihova seniora, napravio je Tomaš s hrvatskom vlastelom klasičan vazalni ugovor, ali se već sljedeće godine Doroteja Blagajska našla pod zaštitom gubernatora Ivana Hunjadija. Može se pretpostaviti da su Doroteju ugrožavali nasljednici vojvode Ivaniša Dragišića iz Donjih Kraja. To znači da joj svojim snagama bosanski kralj nije mogao jamčiti sigurnost i da je zaštita ugarskog gubernatora za nju ipak imala veću vrijednost. Tomaševa isprava Doroteji Blagajskoj ... odraz je njegova nastojanja da se blagajski knezovi u graničnoj feudalnoj oblasti župe Vrbas ... tješnje vežu za politički okvir bosanske krune. U svijetu parcelizirane feudalne politike - osobito na osjetljivim dodirnim graničnim točkama - svaka je strana nastojala vrbovati pristalice i 'podebljati' liniju razgraničenja. Feudalni klanovi oko kojih su se lomila koplja - vrijedno je podsjetiti na Hrvatiniće - znali su iz tih igara izvući maksimalnu dobit. Godine 1448. preudala se Doroteja za kneza Martina Frankapana donijevši mu u miraz utvrde Kozaru (Kozarac) u Sanskoj

5 Usp. Dubravko Lovrenović, Na klizištu povijesti. Sveta kruna ugarska i Sveta kruna bosanska 1387-1463, Synopsis, Zagreb - Sarajevo, 2006. Usp. također Mladen Ančrć, "Kako popraviti prošlost. Konstrukcija memorije na nadgrobnim spomenicima 15. stoljeća", u: Povijesni prilozi, 34, Zagreb, 2008., str. 86, bilj. 10.

6 Usp. Esad Kurtović, "Legitimitet bosanske krune", u: Zeničcke sveske - Časopis za društvenu fenomenologiju i kulturnu dijalogiku, 4, Zenica, 2006.; Aмır KLiкo, "Na klizištu povijesti", u: Baština, 2, Sarajevo, 2006.; EmIR O. Filipović, "Történelmi földcuszamlás - Magyarország Szent Koronája és Bosznia Szent Koronája, 1387-1463", u: Klió történelmi szemlézó folyóirat, 3, Debrecen, 2007. - isti je tekst u prijevodu na engleski jezik objavljen dva puta, prvo kao "Between the Ottoman Hammer and the Hungarian Anvil (Dubravko Lovrenović)", u: Hungarian Quarterly, XLIX/109, Budapest, 2008., a onda pod naslovom "Dubravko Lovrenović: Na klizištu povijesti (Sveta kruna ugarska i sveta kruna bosanska 1387-1463), Synopsis, Zagreb - Sarajevo, 2006., 808 pp.", u: Radovi: Historija, Historija umjetnosti, Arheologija, XIV/1, Sarajevo, 2010. s nekoliko sitnih razlika. 
županiji i Vrbas s istoimenom župom. Posjed Levač s utvrdom i selom istoga imena založila je u ovoj pograničnoj županiji pred požeškim kaptolom 17. IX. 1449. vlasteoska porodica Dobra Kuća - ogranak Nelipčića - bratu kralja Tomaša Radivoju Ostojiću i njegovu tastu Nikoli Veličkom."7

Ovaj kratki ulomak na prvi pogled uobičajenoga povjesničarskog diskursa (u kojem postoji tanana ili nikakva veza u redanju činjenica i "činjenica" prikupljenih iz raznih dokumenata) zapravo je prepun općih mjesta, materijalnih pogrješki i promašenih izričaja. Zavjernicu o zaštiti u drugoj rečenici autor pretvara u "klasičan vazalni ugovor", a da pri tomu sam dokument ne daje niti najmanje mogućnosti za to. Da bi bio "vazalni ugovor" on bi morao sadržavati i barem naznaku obveza druge strane, čega u zavjernici nema ni u tragovima, a ni ne može biti jer takvih ugovora jednostavno u ovome dijelu svijeta u 14. i 15. stoljeću (kao vremenu na koje se autor fokusira) nije bilo. U sljedećoj se misaonoj cjelini (rečenici) Doroteja "našla pod zaštitom" drugoga moćnika, pa nije jasno je li ona tu zaštitu tražila ili joj je bila nametnuta. Cini se da autor smatra kako ju je Doroteja sama tražila (ali u tome se slučaju nije mogla "naći pod zaštitom") jer joj bosanski kralj nije pružao dostatnu zaštitu od nasljednika Ivaniša Dragišića, a "ugarski gubernator" (sukladno pravcu argumenta) jest. Tvrdnja možda čak i može izdržati provjeru u sačuvanim izvorima, ali je ona za središnju tezu autorova djela, onu o samostalnosti i suverenosti bosanskoga kralja, zapravo pogub- na, jer su "nasljednici Ivaniša Dragišića" podanici bosanskoga kralja. Ako, pak, on nije bio u stanju pružiti zaštitu od svojih podanika a "ugarski gubernator" jest, onda to na odnose između "kralja" i "gubernatora" baca posve određeno svjetlo. No, nevolje s autorovim argumentima ovdje se ne završavaju: unatoč tomu što nije mogao pružiti dostatnu zaštitu od svojih podanika (osobi s kojom je sklopio "klasičan vazalni ugovor"), bosanski je kralj "blagajske knezove" (N.B.: Doroteja i njezin sin su se neopazice pretvorili u "blagajske knezove", samo je pitanje jesu li to i ostali nakon što se Doroteja ubrzo "preudala za Martina Frankapana") htio "tješnje vezati za politički okvir bosanske krune". Želja za nekom vrstom "vezivanja" svakako je u temelju zavjernice pa je pitanje zašto to uopće treba navoditi, no "politički okvir bosanske krune" posve je nerazumljiva kategorija (osim valjda samome D. Lovrenoviću). Što to znači i gdje se to značenje dade raspoznati? Takva, međutim, kakva je, ta kategorija posve korespondira $s$ drugom kategorijom koja se pojavljuje po prvi put u ovoj rečenici - "feudalna oblast župe Vrbas", koja će se malo kasnije pretvoriti samo u "župu Vrbas", ali i u "županiju Vrbas". Čitatelj će se s pravom pitati: što je Vrbas? "Feudalna oblast", "župa" ili "županija"? No, u rječniku D. Lovrenovića nisu samo oblasti "feudalne" - takva je i "parcelizirana politika", ali su takvi i "klanovi" (dok značenje prvih dvaju kategorija, "feudalnih oblasti" i "feudalne parcelizirane politike" ostaje posve zagonetno, barem je za "feudalne klanove", poglavito kad se autor 
pozove na primjer Hrvatinića, jasno da se radi o širim rodbinskim zajednicama, za koje se, posve neovisno o D. Lovrenoviću, doista barem u engleskome jeziku koristi oznaka clans, ali se nikad i nigdje ne nazivaju "feudalnim"). Ovakvo isprazno ponavljanje pojma "feudalni" kao neke vrsti poštapalice ili sinonima za pojam "srednjovjekovni" (što je i razumljivo za autora koji vidi "klasični vazalni ugovor" tamo gdje mu nema ni traga) natjeralo je prije dvadesetak godina (očigledno tada ogorčenu) englesku povjesničarku Susan Reynolds na pisanje još i danas popularne knjige, ${ }^{8} \mathrm{u}$ kojoj taj rašireni običaj podvrgava temeljitoj raščlambi i utvrđuje puni besmisao takva postupka. No, u zadnjoj se rečenici "feudalni klanovi" promeću u "vlasteosku porodicu" koja u pravnim poslovima nastupa kao osoba, što pokazuje da autor nije ni pokušao razaznati tko su akteri transakcije o kojoj govori (u pravnim poslovima koji se završavaju pred srednjovjekovnim kaptolima u Ugarsko-Hrvatskom Kraljevstvu nikad "porodica" ne nastupa kao "osoba" ili "korporacija"). Riječ je zapravo o tomu da D. Lovrenović doslovce preuzima informaciju iz jednoga bizarnog teksta, objavljenog u još bizarni- joj publikaciji koja danas teško da može služiti kao bilo što drugo do vrelo za poznavanje duhovnih i intelektualnih prilika kakve su vladale u Beogradu u prvoj polovici 90-ih godina 20. stoljeća. Riječ je o tekstu beogradskoga povjesničara Miloša Blagojevića, jedne od perjanica one vrsti "nacionalne povijesti" koja potječe iz 19. stoljeća i koja se u toj neizmijenjenoj formi grozničave potrage za Srbima kao "glavna struja" akademske produkcije održava poglavito u Beogradu. ${ }^{9}$ Upravo je odatle D. Lovrenović preuzeo dobar dio u najboljem slučaju čudnih tvrdnji koje se pojavljuju u ovome kratkom isječku iz njegove knjige - i "vlasteosku porodicu Dobrakuća" (samo što je to ispravio u Dobra Kuća), i "ogranak Nelipića" koji je on pretvorio u "ogranak Nelipčića" (iako je riječ zapravo o potomcima kneza Nelipca pa su "Nelipići" upravo zato da bi ih se razlikovalo od "Nelipčića" iz Cetine, s kojima naravno nemaju nikakve veze, a što se sve u historiografiji zna još od 1918. godine, odnosno objavljivanja jedne važne studije Ferde Šišića. ${ }^{10}$ Nelipac o kojemu je tu riječ inače je bio sin Grgura Pavlovića, pripadnika široke rodbinske zajednice donjokrajskih Hrvatinića, što je čini se znao i M. Blagojević,

8 Usp. Susan Reynolds, Fiefs and Vassals: The Medieval Evidence Reinterpreted, Clarendon press, Oxford, 1996.

9 Vidi: Miloš Blagojević, "Severna granica bosanske države u XIV veku", u: Stavenko TERzIĆ (ur.), Bosna i Hercegovina od srednjeg veka do novijeg vremena, Istorijski institut SANU - Pravoslavna reč, Beograd - Novi Sad, 1995., str. 65. O specifičnoj "školi nacionalne povijesti" koja se razvila i održava u Beogradu pisao sam u dva navrata te tome ne bih ništa u ovoj prigodi dodavao (vidi: M. ANČıć, Na rubu Zapada..., str. 143-146; Isti, "Što je Bosna bez Hercegovine", u: Status, 8, Mostar, 2006., str. 71-73), ali bih upozorio na kratki prikaz trendova srpske medievistike u: NADA ZeČević, "Medieval Studies in Serbia 1993-2008", u: Annual of Medieval Studies at CEU, 15, Budapest, 2009., gdje su izložena vrlo slična stajališta u blažoj formi.

10 Vidi: Ferdo Šıšić, "Iz arkiva grofova Pongraza", u: Starine JAZU, 36, Zagreb, 1918., str. 31. 
jer on uz izričaj o "ogranku Nelipića" dodaje u zaporci objašnjenje Nelepech te sljedeću rečenicu započinje riječima "Nelipčevi unuci", samo što D. Lovrenović očito nije shvatio što stoji iza izričaja beogradskoga povjesničara). Iz istoga vrela potječe i "posjed Levač $s$ utvrdom i selom istoga imena" - kod Blagojevića je to "posed Levač" koji se sastojao "od kastela po imenu Levač i sela (villa) istog imena". Dok je za M. Blagojevića očekivano da govori o "Levaču" jer je on "posed", valja ipak priznati da je čak i on bio toliko obziran te notirao činjenicu kako se na poleđini dokumenta o kojem je riječ nalazi suvremena ćirilična bilješka "založni list 'na Livač"'11 pa je iz toga zaključio da su "Levač i Livač jedno te isto". Tko god pak drži do svoga posla povjesničara, naravno ako ne pripada "beogradskoj školi" koja svuda vidi "Srbe" i "ekavicu", odnosno dijeli svijet na "Srbe" i "one koji to nisu", koristio bi formu Livač kao izvorni oblik toponima, a ne po današnjoj logici "političke korektnosti" oblike "Ljevač" ili "Lijevče", jer nema nikakva dokaza da su oni bili u uporabi u srednjem vijeku. ${ }^{12}$ No, kako god nazivali Livač, on svakako nije bio "selo" jer je tamo postojao franjevački samostan, izgrađen u 15 . stoljeću, a tko god zna nešto o srednjovjekovnom svijetu zna i to da se franjevački samostani nisu gradili po

11 Tu informaciju donose priređivači ugovora u tiskanom izdanju. Usp. Lajos Thallóczy - SÁndor Horváth, Alsó-szlavóniai okmánytár (Dubicza, Orbász és Szana vármegyék), MTA, Budapest, 1907., str. 178.

12 Tako primjerice Stanko Andrić, "O obitelji bosanskog protukralja Radivoja Ostojića", u: Ante Birin (ur.), Stjepan Tomašević (1461.-1463.) - slom srednjovjekovnoga Bosanskog Kraljevstva, Hrvatski institut za povijest - Katolički bogoslovni fakultet u Sarajevu, Zagreb - Sarajevo, 2013., str. 119, koristi oblik "Ljevač", naznačujući u zaporci latinski oblik (Lewach), ali bez upute na ćiriličnu bilješku s oblikom "Livač". U posrednoj svezi, pak, s tim Livačom/Ljevčem potkrao se S. Andriću jedan prilično nespretan izričaj. Govoreći, naime, o sklapanju braka Radivoja, brata bosanskoga kralja Stjepana Tomaša, 1449. godine Andrić razlaže dokumente koji govore o sastavljanju i zapisivanju različitih ugovora između Radivoja i oca njegove buduće žene, Nikole Veličkoga, te precizira njihove datume - 19. lipnja 1449. i 17. rujna 1449. (S. AndRIć, "O obitelji...", str. 115, 119). Nastojeći, pak, otkriti okolnosti koje su mogle spojiti Radivoja i Nikolu Veličkoga, uočava Andrić misiju mačvanskoga bana Ivana Korođskoga (čiji je familijar bio Nikola Velički) u Bosni precizno datiranu pisanom izjavom kralja Stjepana Tomaša izdanom 11. studenoga 1449., pretpostavljajući da su banov familijar i kraljev brat tada došli u kontakt i dogovorili brak te nastavlja: "Ubrzo nakon što su dogovorili brak između Radivoja i Katarine Veličke te utanačili uzajamne imovinske obveze, Nikola Velički i Radivoj Kotromanić zajedno su se latili širenja svojih sada združenih imanja." (S. ANDRIć, "O obitelji...", str. 118-119). Izgleda, dakle, da su Radivoj i Nikola dogovorili brak i u svezi s time združili imanja 19. lipnja 1449., potom 17. rujna iste godine ušli u zajednički pothvat uzimanja pod zalog Livča, da bi se nakon svega toga našli u Doboru 11. studenoga gdje su im se putanje preklopile na političkim pregovorima i tom se prigodom "upoznali"! Naravno, ukoliko su doista sudjelovali u dogovorima koji su rezultirali izjavom Stjepana Tomaša od 11. studenoga 1449. Radivoj (kraljev brat) i Nikola Velički (familijar ugarskoga izaslanika Ivana Korođskoga) već su bili punac i zet, a uzme li se u obzir da su 17. rujna bili zajedno pred požeškim kaptolom, moglo bi se čak pretpostaviti da su zajedno došli u Dobor (ako su tamo doista i bili). To, pak, opet baca posve drugačije svjetlo na odnose bosanskoga kralja i gubernatora Ivana Hunjadija, svakako ne onakvo kakvo bi primjerice želio D. Lovrenović. 
"selima". ${ }^{13} \mathrm{Za}$ postojanje franjevačkoga samostana u Livču ("Levču") zna čak i Lovrenoviću omiljena i u njegovu djelu često citirana autorica još jednoga ezoteričnog djela "beogradske škole", Jelena Mrgić-Radojčić, ${ }^{14}$ a o kakvu je djelu riječ dovoljno jasno govori činjenica da autorica "zna" kako pravoslavno pučanstvo u 14 . stoljeću živi "u Glažu ... u blizini Otoka na Uni, Krbave i Modruša, Knina i Vrhrike (oko gornjeg toka Cetine), Vrbasa i Save (Sane?)".15 Kako je pak autorica došla do tih "revolucionarnih" spoznaja? To su odreda lokaliteti na kojima su podignuti u 14. stoljeću samostani franjevačke Bosanske vikarije, a kako se u papinskim bulama izdanim u svezi s podizanjem franjevačkih samostana, poglavito pak na području savsko-drinsko-dunavskoga interamnija - jugoistočni obod $\mathrm{Pa}-$ nonske nizine, redovito spominju i "šizmatici", jednostavno je zaključila da je ista takva situacija vladala svuda gdje su podizani samostani vikarije. Iz takvoga "znanja" onda proizlazi i zaključak koji izaziva pravu nevjeri$\mathrm{cu}$, prema kojemu je na razmeđu 14 . i 15. stoljeća "Split pretežno katolička sredina", ${ }^{16}$ uza što se odmah naravno postavlja pitanje koliko je to "pretežno", 60 ili $70 \%$, i tko su, odnosno što su oni koji nisu katolici? Zašto je sve ovo važno? Zato što to i takvo djelo D. Lovrenović ubraja, ni više ni manje nego među "izuzetno vrijedne monografije srpske medievalistike", ${ }^{17}$ i jer je tu, po svemu sudeći, našao inspiraciju i za neka od svojih "velikih otkrića". D. Lovrenović, kao i J. Mrgić-Radojčić, "zna" stvari koje drugi povjesničari "ne znaju". Primjerice on "zna" da je "(p)ovremena hegemonija Bizanta uvela također grčko stanovništvo, posebno u Zadar i Split. Za vrijeme intervala vlasti Ugarske najveći dio grčkih crkava dan je katolicima. Godine 1314. posljednja pravoslavna crkva u Dalmaciji bila je konfiscirana, a njezini svećenici prisiljeni da obrede obavljaju u privatnim kućama". ${ }^{18}$ Odakle je crpio ove "spoznaje" sam D. Lovrenović ne otkriva. $\mathrm{Ne}$ bi valjalo nagađati zašto ne citira djelo kojim se služio, no nije bilo teško utvrditi vrelo ovih nebuloznih tvrdnji. Već u prvoj instanci provjere posegnuo sam za djelom episkopa $\mathrm{Ni}$ kodima Milaša ${ }^{19}$ i naravno našao ono što sam tražio. Tu se mogu naći "informacije" o jakim "grčkim kolonija-

13 Za franjevački samostan u Livču vidi: Nikola Bilogrivić, Katolička crkva na području današnje banjalučke biskupije do invazije Turaka, Vrhbosanska katolička bogoslovija, Sarajevo, 1998., str. 270 i d.

14 Jelena Mrgić-Radojčić, Donji Kraji. Krajina srednjovekovne Bosne, Filozofski fakultet u Beogradu, Beograd, 2002., str. 147. Osvrt vidi u: M. Ančıć, "Što je Bosna...", str. 71-73.

15 J. Mrgić-Radojčić, Donji Kraji..., str. 143.

16 Isto, str. 147.

17 D. Lovrenović, Na klizištu povijesti..., str. 17.

18 Isto, str. 719.

19 E.N.M., Pravoslavna Dalmacija, Novi Sad, 1901. Ponajbolju karakteristiku toga "sočinjenija" predstavlja činjenica da je njegov pretisak svjetlo dana ugledao 1989. godine u Beogradu, danas je to već posve izvjesno, kao dio priprema za rat u bivšoj Jugoslaviji, sa svim implikacijama koje to podrazumijeva. 
ma u Splitu i Zadru", ${ }^{20}$ o "progonima pravoslavnih" te pripovijest o "oduzimanju posljednje pravoslavne crkve u Šibeniku 1314."'21 Zapita li se, pak, radoznali čitatelj odakle je N. Milaš sve to "znao", a da tim i takvim stvarima nema niti traga u relativno bogatom materijalu vrela po gradovima o kojima je riječ, odgovor je jednostavan iz "Ljetopisa" još jednoga episkopa, Simeona Končarevića. (Sapienti sat).

Što je dakle pokazala raščlamba ovoga kratkog ali znakovitog ulomka iz knjige D. Lovrenovića? Osim što nije istražio arhivski materijal za svoju knjigu (zapravo doktorsku disertaciju) pa ne zna za oporuku Ivaniša Blagajskog, ${ }^{22}$ ali ni za mnoštvo drugih dokumenata koji su ključni za ono o čemu želi pisati, D. Lovrenović ne zna ni što bi s onim što je uspio prikupiti (a što, valja i to priznati, ipak nije malo). Njegov se postupak, kako sam pokazao, svodi na asocijacije koje slijede prikupljene činjenice (i "činjenice"23) "logikom zdravog

20 E.N.M., Pravoslavna Dalmacija, str. 115.

21 Isto, str. 153.

22 Onaj tko želi pisati o odnosima Bosanskoga Kraljevstva sa sjevernim i zapadnim susjedstvom mora, između ostaloga, neizostavno pregledati sav materijal arhiva zagrebačkoga kaptola iz toga doba jer će u njemu naći vrlo vrijedna vrela bez kojih će spoznaje o ovome dobu ostati nekompletne (quod est demonstrandum). U tome poslu tek je početna faza konzultirati tri sveska te građe koje je tiskao Andrija Lukinović (ANDRIJA LuKInović, Povijesni spomenici zagrebačke biskupije, V./1992., VI./1994. i VII./2004.), od kojih D. Lovrenović zna za (i vjerojatno je vidio, ali nije sigurno i da je knjigu otvorio) samo jedan, onaj pod brojem V. (Dvojbe oko toga je li knjigu otvorio proizlaze iz činjenice da u popisu literature na kraju svoga djela - D. Lovrenović, Na klizištu povijesti..., str. 730 - tu zbirku vrela citira prema naslovu na ovitku, gdje nema broja sveska, koji se međutim nalazi u sklopu naslova na prvoj stranici). No, prije nego što se povjesničar koji ima namjeru pisati o temi koje se poduhvatio D. Lovrenović upusti u istraživanje arhiva zagrebačkoga kaptola, mora podrobno istražiti fond isprava iz razdoblja prije 1526. godine u Mađarskom državnom arhivu (riječ je o dvije zbirke: Diplomatikai Levéltár i Diplomatikai Fényképgyűjtemény), što mu onda može uštedjeti i istraživanje u zagrebačkome arhivu, jer je najveći dio tamošnjih dokumenata pohranjen u Budimpešti u obliku fotografija. Naravno, D. Lovrenović taj dio posla nije obavio, pa je već na toj razini posve diskvalificiran za pisanje o temi koju je izabrao!

23 Iako umjesno (barem u početnom impulsu) inzistira na dekonstrukciji diskurzivne stigmatizacije političkih protivnika religijskim pojmovima (D. Lovrenović, Na klizištu povijesti..., str. 587-613), D. Lovrenović nije iz toga izvukao dosljedne zaključke. Naime, ako uporaba vjerski diskvalificirajućih karakterizacija u pisanoj komunikaciji ukazuje na to da (službeni) dokument nije vjerno zrcalo stvarnosti, onda se taj zaključak mora ugraditi i u odnos spram drugih dijelova istih dokumenata, primjerice spram "naracije" kraljevskih privilegija, onoga dijela teksta dokumenta koji donosi "pripovijesti" o zaslugama destinatara tih istih privilegija, a koje autor tretira kao posve neproblematično vrelo spoznaja o "događajima" (o čemu postoji i relevantna literatura o kojoj D. Lovrenović ništa ne zna). Čak i kada sam primijeti nesklapnosti u "naracijama" različitih dokumenata, D. Lovrenović ne zna što bi počeo s uočenim, jer nije istražio ono o čemu piše. Usp. D. Lovrenović, $\mathrm{Na}$ klizištu povijesti..., str. 255: "Dok se prema opisu ugarske kancelarije Turci nisu usudili pružiti baš nikakav otpor, na drugom mjestu se kaže da su prilikom osvajanja Hodidjeda mnogi od Talovčevih znamenitih familijara izgubili život." U bilješci (bilj. 297) kojom je popraćen navod o Hodidjedu, koju prenosi iz Klaićeva davnoga djela koje rijetko tko uopće danas i citira, stoji međutim nešto posve drugo. Riječ je tamo o pohodima Matka Talovca koji su vodili do osvajanja Sinja u Kraljevini Hrvatskoj 
razuma", pri čemu pokazuje zavidno nerazumijevanje kategorijalnoga aparata srednjovjekovnoga svijeta, iako popis korištene literature daje za pravo zaključiti kako je autor pročitao dovoljno djela da mu to ne bi smjelo predstavljati problem. No, i na toj se razini dade ipak razabrati gdje je problem D. Lovrenovića: pojava krajnje ezoteričnih naslova, jer se uz Pravoslavnu Dalmaciju, koju nije želio citirati, na popisu njegove literature i vrela nađu i već odavno zaboravljena djela poput Opšte privredne istorije Heinricha Cunowa ili "sočinjenija" franjevca Antuna Kneževića Kratka Povijest kralja bosanskih i Pad Bosne, pa čak i pseudo-znanstvena djela, kakva je Dvornikovićeva Karakterologija Jugoslovena, pokazuje da D. Lovrenović nije razvio i nema sposobnost razlikovati važno od nevažnoga (ba- rem ako je riječ o znanstveno-istraživačkom postupku). Povjesničar koji ozbiljno tretira djela pisaca iz 17. i 18. stoljeća (Mavro Orbini i Daniele Farlati) kao prvorazredna vrela za krunidbu prvoga bosanskog kralja, ${ }^{24}$ Tvrtka I. Kotromanića, očito ima problema s onim elementarnim postulatima i pravilima posla kojim se želi baviti. Takvome očito nije jasno da (doduše kvalificirani, a ne svaki) povjesničar danas zna mnogo više o tim zbivanjima no što su znali $M$. Orbini i D. Farlati, s njihovim skromnim vrelima spoznaja o nečemu što se dogodilo stoljećima prije nego što su oni pisali. Do istoga se, međutim, zaključka o nesposobnosti razlikovanja važnoga od nevažnoga dolazi i s pogledom na cjelinu Lovrenovićeva uratka. Sakupivši golemu količinu činjenica, autor se jednostavno izgubio

i Hodidjeda u Bosanskom Kraljevstvu (in ... recuperacionibus castrorum Zyn in Croacie et Hodided in Bosnensi regnis). Svaki bi povjesničar, koji se drži pravila svoga "zanata", krenuo tragom dostupnih vijesti i pokušao razabrati što je tu na stvari. Je li doista pohod Matka Talovca protiv turskih snaga u Bosni prošao relativno glatko a sukob pod Sinjem odnio živote njegovih familijara, ili je riječ o nečem drugom, trećem... No, zato treba biti povjesničar koji zna istraživati!

24 Danas povjesničari iz Farlatijeva monumentalnoga djela Illyricum sacrum citiraju gotovo isključivo dokumente koje on donosi, a koji se nisu kasnije pretiskavali. O krunidbi prvoga bosanskog kralja Farlati je znao samo ono što je našao kod Orbinija, pa je na tome temeljio svoja domišljanja, kako je to jednostavno i odavno sročio Đuro Basler tvrdeći kako ovaj "prepisuje Orbinija uz neke preinake". No D. Lovrenović na to odgovara "očaravajućim" argumentom koji doista izaziva nevjericu: "Teško je zamisliti da je učeni isusovac u igru omaškom uveo 'mitropolita ili igumana mileševskog bazilijanskog manastira' i predaju kraljevskih insignija, što su u odnosu na Orbinija novi detalji" (D. Lovrenović, $N a$ klizištu povijesti..., str. 647, bilj. 471). Što je i kako "učeni isusovac" doista "uvodio u igru" ponajbolje se vidi iz njegove tvrdnje da su Bijaći (mali kompleks kasnoantičke/ranosrednjovjekovne crkve, s gospodarskim objektima ranoga curtisa, gdje su hrvatski knezovi Trpimir i Muncimir dali sastaviti isprave u korist Splitske nadbiskupije) bili "najstariji i najslavniji grad" kamo su hrvatski vladari prenijeli svoje "kraljevsko sjedište" (citirano prema: Daniele Farlati, Illyrici sacri tomus primus, Venetiis, 1751., str. 481). Što se, pak, Orbinija tiče, on je znao ono što je pročitao u izgubljenoj Istoriji Kotromanića (djelu vjerojatno franjevačke provenijencije, čije je postojanje i temeljni sadržaj izvan svake razumne dvojbe dokazao Sima Ćirković), pri čemu je ipak, kao i Farlati, bio spreman koješta "uvoditi u igru", odnosno "domišljati" koliko mu je dopuštao horizont njegovih spoznaja. Tretirati ozbiljno takva djela kao prvorazredna vrela protivno je svim pravilima modernoga "povjesničarenja" (moderne historiografije)! 
u "pripovjedačkoj šumi" (razvidno je to i po podnaslovima kroz cijelo djelo, koji daju "siže" svakoj kraćoj narativnoj sekvenci), pri čemu je to pripovijedanje samo sebi svrha, jer nema nikakvu organsku vezu $s$ teorijskim dijelom teksta, u kojem autor konačno pokušava objasniti razlog zašto je knjigu naslovio onako kako ju je naslovio.

Tu valja odmah reći: D. Lovrenović sabrao je popriličnu količinu informacija koje govore o razvoju ideje vlasti i njezine reprezentacije za široki europski prostor, ali te informacije nije uspio dovesti u svezu s onim što je predmet kojim se sam bavi. Prvi je njegov problem činjenica da nigdje u sačuvanim vrelima nije mogao naći pojam "sveta kruna bosanska" koji je stavio u naslov svoga djela! To naravno ne znači negiranje mogućnosti da se taj pojam možda nekad i negdje doista $\mathrm{i}$ koristio, ali ne postoji nijedno vrelo $\mathrm{u}$ kojem se on pojavljuje. Ne samo to, ne postoji niti jedno pisano vrelo nastalo od domaćih autora (u bilo kojoj formi) kojim bi se moglo dokazivati da se pojam "kruna" uopće koristio kao apstraktna inačica ideje "države", barem kad je riječ o samome Bosanskom Kraljevstvu. U Bosni je, naime, redovito rabljen pojam "rusag". Indikativno je da D. Lovrenović ne ulazi u raščlambu etimologije toga pojma, jer bi ga to dovelo u krajnje neugodan položaj. Riječ je o posuđenici, riječi ország, koja potječe iz mađarskoga jezika, a i danas je u uporabi u tom jeziku u značenju "država" ili "zemlja". Pojam je ušao i u hrvatski i u srpski jezik kao "rusag" i "orsag", ali i u bo- sanski, ako povjerujemo da su u srednjovjekovnoj Bosni, tome "rusagu", svoj jezik doista zvali "bosanskim". Još nitko, međutim, nije pronašao ni jedan pisani trag takvu nazivu, pa stoga zadržavam skepsu glede mogućnosti korištenja takvoga naziva za jezik u srednjem vijeku. Bilo kako bilo, trebalo bi prikupiti doista jasne dokaze da je "rusag" bilo kad i bilo gdje napušten za račun pojma "kruna" ili "sveta kruna". No, takvih dokaza u poznatim vrelima nema i uzaludno ih je tražiti. Što u takvoj situaciji radi D. Lovrenović? Poput studenta koji sprema ispit, on slaže tuđe ideje i praksu iz raznih dijelova srednjovjekovne Europe u neku vrst "skripte", a onda to proglašava "bosanskim iskustvom". Pogledajmo kako to izgleda:
"Pravna koncepcija bosanske krune (N.B.: nikad i nigdje zabilježen po- jam - op. M.A.) razvila se pod utjeca- jem bliskog ugarskog modela. Preko apstraktnog shvaćanja države bili su kruna i sabor - prvo kao simbol vladar- skog dostojanstva, drugo kao oličenje kolektivne volje bosanskog plemstva neraskidivo povezani u 'sav rusag bo- sanski', oznaku zajedničkog okvira djelovanja najvažnijih konstituenata države. Na temelju ove koncepcije for- mirana je predodžba o kraljevstvu kao jednome 'tijelu' s 'glavom' i 'udovima', ili jednoj na 'stupovima' utemeljenoj 'kucí'."25

Poslije ovoga bi čitatelj očekivao eksplikaciju takvih stajališsta u kakvome opširno prenesenom vrelu, čime bi se potvrdilo gornje izvođenje. No, umjesto toga u bilješci će D. Lovrenović čitatelja uputiti na nešto što $s$ Bosnom, ni onom srednjovjekovnom 
ni bilo kakvom, nema nikakve, odnosno nikakve izravne veze - na enciklopedijsku odrednicu Reich u jednoj njemačkoj enciklopediji te na knjigu Jánosa Baka o kraljevstvu i staležima u srednjovjekovnoj Ugarskoj. Osjećajući da to ipak nije dovoljno, pokušat će D. Lovrenović dalje razvijati svoju teoriju svojevrsnom podvalom, pa veli: "Precizno raščlanjene uloge koje odslikavaju ovako shvaćen društveni poredak sadržane su u povelji kralja Stjepana Ostojića Dubrovčanima (5. III. 1419.)." Citanjem, ali i usporedbom toga dokumenta s drugim sličnim što su ih izdavali bosanski kraljevi nakon Tvrtka I. Dubrovniku, ${ }^{26}$ nemoguće je pronaći ono što u njima "vidi" D. Lovrenović ("teoriju države", držimo li se pompoznoga Lovrenovićeva stila), kao što je nemoguće uočiti bilo kakve diskurzivne promjene (a o tomu je, valjda, riječ) u odnosu na ranije izdane privilegije (to je razlog zašto D. Lovrenović ne citira suvislu cjelinu teksta iz dokumenta na koji se poziva). No, zato će se u svim tim dokumentima naći nešto na što povjesničari dosad (ni oni prije Lovrenovića, uključujući i potpisnika ovih redaka) nisu obraćali pozornost, a što govori zapravo suprotno od onoga argumenta koji razvija autor. Riječ je, naime, o tomu da se u svim tim dokumentima pojavljuje pojam "kraljevstvo" za oznaku kraljevske vlasti ali i osobu kralja, ${ }^{27}$ što na iznenađujući način upućuje na duboko usidrene misaone strukture $s$ ishodištem još iz ranoga srednjeg vijeka, ako ne i ranijih vremena. Naime, ta konstrukcija i njezina uporaba korespondiraju $s$ onim što je u sklopu svojih "etnoloških" zabilješki nastalih iz posjete rubnim dijelovima Karolinškoga Carstva (Hrvatska Kneževina) i susjednim područjima koja su bila pod vlašću cara u Konstantinopolju ("gradovi na moru" Venecije i gradovi na istočnoj obali Jadrana) još sredinom 9. stoljeća (vjerojatno zapisao te) koristio kao argument teoloških rasprava Saksonac Gottschalk. Učeni karolinški teolog zapazio je jednu, iz njegova očišta, neobičnost u govoru stanovnika "gradova" mletačkih laguna, gradova na istočnoj obali Jadrana ali i ruralnoga svijeta Hrvatske Kneževine u njegovu dubljem zaleđu te je to ovako opisao:

\footnotetext{
"Tako se, dakle, za boga kaže boštvo i božanstvo. Isto tako Dalmatinci, a na sličan način i Latini, (koji su - op. M.A.) pak podložni carstvu Grka, po čitavoj Dalmaciji, uistinu vrlo velikoj pokrajini, kažem, u svakodnevnome govoru kralja i cara nazivaju kraljevstvo i carstvo. Kažu naime: Bili smo kod kraljevstva i Stali smo pred carstvo
}

26 Vidi: Franz Miklosich, Monumenta Serbica spectantia historiam Serbiae, Bosnae, Ragusii, Apud Guilelmum Braumüller, Viennae, 1858., str. 220-222, br. CCVI, 17. 7. 1392 .; 235-237, 5. 2. 1399., br. CCXXVI; 272-273, br. CCLIV, 4. 12. 1409.

27 Isto, str. 236: "i kralevstvo mi slišav'še i razumiv'še"; str. 273: "stvori milost' kralev'stvo mi". Izrazito se jasno takav oblik oznake za vlast raspoznaje u ugovoru o miru između dubrovačke općine i Odole Predenića, predstavnika stanovnika Krajine (obalnoga područja između Neretve i Vrulje u Makarskome primorju), sastavljenome u Dubrovni$\mathrm{ku}$ 11. veljače 1247. Slovom toga ugovora Odola se obvezao "da Krainanje ne pakoste Dubrov'čanom' ... ni onem' ki su pod knez'tvo ih ... i u predelih' knez'stvo ih nikomurje". Ljubomir Stojanović, Stare srpske povelje i pisma, I., Srpska kraljevska akademija, Beograd - Sr. Karlovci, 1929., str. 22, br. 24. 
i Tako nam je reklo kraljevstvo i Tako nam je govorilo carstvo." ${ }^{28}$

No, vraćajući se D. Lovrenoviću valja upozoriti kako upravo isprava kralja Stjepana Tomaša od 25. svibnja 1446., o kojoj je bilo govora na početku ovoga teksta, jasno proturječi njegovim teorijskim "izvođenjima" jer se u njoj paralelno govori o dvama Kraljevstvima, onome Ugarsko-Hrvatskom i onome Bosanskom. Za vlast, odnosno vladare onoga prvog se i eksplicitno koristi pojam "kruna ugarska" ("što bi imali pravde i zapise ot krune ugr'ske" - naglasio M.A.; "što e sada pod' krunom' ugr'skom"' - naglasio M.A.), dok za vlast svoga "gospodina" (i njegove prethodnike) pisar Stjepana Tomaša koristi pojam "kraljevstvo" ("što bi u rukah' kralev'stva našega"; "niedan' človek kralev'stva našega").

Zašto ideja o "kruni" kao "transpersonalnome simbolu" Bosanskoga Kraljevstva nije bila prihvaćena (ili barem to prihvaćanje nije zabilježeno u sačuvanome i poznatom fondu vrela), iako je to značenje bilo poznato ako nigdje drugdje ono u dvorskome kru- gu sredinom 15. stoljeća (kako pokazuje upravo citirani primjer) teško je, ako ne i nemoguće odgovoriti. Jedini primjer uporabe pojma "kruna" koji je D. Lovrenović našao u sačuvanome fondu vrela jest zapravo jasna kasnija krivotvorina, što autora nije spriječilo da "razvije" svoju misao, kršeći pri tomu čak i temeljna pravila znanstvenoga rada glede načina postupanja $s$ tuđim mislima kao intelektualnim vlasništvom. Evo kako to izgleda u Lovrenovićevoj izvedbi:
"(D)ok je banski period vladarske ča- sti do proglašenja kraljevstva još uvijek obilježen patrimonijalnim konceptom države, a kralj Tvrtko I. i njegovi na- sljednici - potvrđujući na prijelomu XIV. i XV. st. Dubrovčanima stare privilegije - već ističu da je to učinilo 'kraljevstvo mi', dotle Stjepan Toma- šević daruje 18. IX. 1461. gradove i zemljišne posjede stricu Radivoju za 'virna i prava posluženja koja posluži kruni kraljevstva našega'. U izrazu 'kra- ljevstvo i kruna' riječ kruna služi da eliminira čisto geografsko-teritorijalni aspekt kraljevstva i da naglasi njegov nedvojbeno politički karakter koji je također uključivao emocionalnu vri-

28 Odlomak izvornoga Gotschalkova teksta glasi: Sic ergo dicitur deitas et divinitas pro deo. Item homines Dalmatini, perinde idem similiter homines Latini Graecorum nihilhominus imperio subiecti, regem et imperatorem communi locutione per totam Dalmatiam longissimam revera regionem regem, inquam, et imperatorem regnum et imperium vocant. Aiunt enim: Fuimus ad regnum et Stetimus ante imperium et: Ita nobis dixit regnum et: Ita nobis loquutum est imperium. Ulomak i prijevod na hrvatski jezik donosi ŽELJKO Rapanić, "Kralj Trpimir, Venecijanci i Dalmatinci u traktatu teologa Gottschalka iz Orbaisa", u: Povijesni prilozi, 44, Zagreb, 2013., str. 40-41. Rapanićev sam prijevod ipak promijenio sukladno drugačijem tumačenju pojma homines Dalmatini. Dok Z. Rapanić smatra da se taj pojam odnosi isključivo na stanovnike "dalmatinskih" gradova, moje je tumačenje da je taj pojam jasno povezan s izričajem o "golemoj provinciji Dalmaciji" (s obzirom na to da je njegovo znanje bilo duboko usidreno u antičko zemljopisno i upravno nazivlje, Gottschalk je vrlo dobro znao "prostranstvo" ili "duljinu" Dalmacije, jer je iz zadarskoga zaleđa s dvora kneza Trpimira otišao u Bugarsku), a da se za stanovnike gradova Gottschalk poslužio pojmom homines Latini Graecorum imperio subiecti. U kontekstu ovdje razmatranih problema upravo ovo tumačenje dobiva potvrdu činjenicom da se takav način govora o nositeljima vlasti ("kraljevstvo", a ne "kralj"), kako je iz već navedenoga razvidno, održavao do duboko u 15. stoljeće. 
jednost domovine - 'kruna kraljevstva je zajednička domovina'."29

Činjenicu da Tvrtko I. i njegovi nasljednici "već ističu" pojam kraljevstvo $m i$ ne bi, s obzirom na prethodno rečeno, ni trebalo komentirati, a što se tiče "patrimonijalnoga koncepta" evo kako jedan od vladara koji je "napustio" takva shvaćanja opisuje što radi: "spodoblen' bjeh' kralestvovati va zemlah' roditel' i praroditel' naših', tvore pravdu i ispralae pravila, čine milosti i zapisanija, vjeru že dae gradovom' i vladanijem', malim' že i velicim', vsakomu že po dostojenijo ego". ${ }^{30}$ Dakle, sve to kralj radi sam, u zemlji na koju pravo polaže isključivo logikom biološkoga naslijeđa, ne videći nigdje "tijelo kraljevine" koje bi s njim sudjelovalo u vlasti (iako je u stvarnosti kraljeva volja na prijelomu 14. i 15. stoljeća bila i te kako ograničena voljom velikaša, tim je onda čudnije što ideja o "kruni" nije našla pogodno tlo u Bosanskome Kraljevstvu). Nakon navoda iz krivotvorene darovnice stricu Radivoju dolazi, međutim, najzanimljiviji dio. U posljednjoj rečenici ulomka samo riječi "kruna kraljevstva je zajednička domovina" stavljene su u navodne znake, nakon čega slijedi bilješka u kojoj se autor poziva na djelo Ernsta
Kantorowicza, pa čitatelj nema druge do pomisliti da je samo tih pet riječi preneseno iz njegova djela, a da je ono prije toga tekst D. Lovrenovića kojim on komentira izričaj iz dokumenta (navodno) nastalog 18 . rujna 1461. Pogleda li se međutim citirana stranica Kantorowiczeva djela, ${ }^{31}$ pokazat će se nešto posve drugo. Tu E. Kantorowicz razvija svoju misao koju treba u cijelosti prenijeti kako bi se moglo jasno razabrati što se od njegovih riječi toliko svidjelo D. Lovrenoviću da ih je pretvorio u svoju misao!
"U izrazu 'glava i Kruna', riječ Kruna služila je kako bi se dodalo nešto obič- nom fizičkom tijelu kralja i kako bi se naglasilo kako se time podrazumijeva- lo nešto više od kraljeva "prirodnoga tijela"; a u izrazu 'kraljevstvo i Kru- na', riječ Kruna služila je da eliminira čisto geografsko-teritorijalni aspekt kraljevstva i da naglasi njegov nedvoj- beno politički karakter koji je također uključivao emocionalnu vrijednost do- movine - 'kruna kraljevstva je zajed- nička domovina' bila je misao pravni- ka što ju je citirao Jacques de Révigny, čiji je suvremenik, William Durand, opravdavao kraljeve izvanredne mjere 'za obranu domovine i Krune'."32

Što je, dakle, uradio D. Lovrenović? Tuđu misao je preuzeo kao svoju i nadovezao je na izričaj iz krivotvo-

29 D. Lovrenović, Na klizištu povijesti..., str. 457.

30 F. Miklosich, Monumenta Serbica..., str. 235, br. CCXXVI, 5. veljače 1399.

31 Ernst H. Kantorowicz, The King's Two Bodies: A Study in Medieval Political Theology, Princeton University Press, Princeton, 1981., str. 341.

32 Kako bi se izbjegle sve moguće dvojbe, citirat ću ovdje izvorni Kantorowiczev tekst na engleskome jeziku: In the phrase "head and Crown" the word Crown served to add something to the purely physical body of the king and to emphasize that more than the king's "body natural" was meant; and in the phrase "realm and Crown" the word Crown served to eliminate the purely geographic-territorial character of regnum and to emphasize unambiguously the political character of regnum which included also the emotional value of patria "the Crown of the kingdom is the common patria" was the opinion of jurists quoted by Jacques de Révigny, whose contemporary, William Durand, justified the king's extraordinary measures "for the defense of patria and Crown". 
rene isprave, izvorni citat iz srednjovjekovnoga spisa kojim se poslužio E. Kantorowicz pretvorio je u njegovu misao te napravio nešto što bi na svakome iole ozbiljnijem sveučilištu bilo kažnjeno oduzimanjem titule (današnja stroga pravila kažu da je više od četiri tude riječi izravno prenesene bez navodnih znakova slučaj plagijata, što se najstrože kažnjava). Prilično sam, međutim, siguran da u sredini u kojoj živi i djeluje D. Lovrenović ovakav oblik plagiranja nikoga ne će ponukati na bilo kakvu reakciju. $U$ toj je sredini tadašnji dekan Pravnoga fakulteta Univerziteta u Sarajevu Fuad Saltaga tuđe djelo, "skriptu" od 65 stranica, objavio kao svoj tekst, bez ikakvih posljedica nakon što je krađa otkrivena, ${ }^{33}$ pa slijedom toga iskustva zaključujem kako se s "ugledom" autora ni u ovome (puno benignijem slučaju) ne će dogoditi ništa. Koliko, pak, ima takvih mjesta na kojima je autor tuđe misli, koje su mu se toliko svidjele da je pomislio kako ih je net- ko njemu ukrao, zapisao kao svoje, ne mogu reći (možda ih doista nema više - ipak je samo jedan E. Kantorowicz), ali to ništa ne mijenja na stvari. Od autora koji tvrdi: "U ovoj terminologiji jasno se ogleda utjecaj rimskog pravnog mišljenja (naglasio M.A.), koji je u Ugarskoj kao i u Bosni (naglasio M.A.) vodio preciznom razdvajanju u označavanju 'državnih subjekata'", ${ }^{34} \mathrm{u}$ situaciji kada je u poznatom korpusu vrela za povijest srednjovjekovne Bosne do sredine 15. stoljeća nemoguće naći ni jednoga obrazovanog pravnika koji bi tu boravio, ${ }^{35}$ kao što je veoma teško pronaći i bilo kakvu informaciju o "pravnim shvaćanjima" u najširem smislu, svašta se može očekivati. Ta je očekivanja D. Lovrenović svakako u stanju ispuniti kako se jasno razabire iz doista briljantne misli prema kojoj "(i)ako bazično identični (naglasio M.A.), konstitucionalni razvoji u Engleskoj i Francuskoj pokazuju znatne i fundamentalne razlike (naglasio M.A.)". ${ }^{36}$

33 Vidi: http://www.oslobodjenje.ba/index.php?id=11289 (20. 5. 2015.).

34 D. Lovrenović, Na klizištu povijesti..., str. 456.

$35 \mathrm{Za}$ prvotnu recepciju srednjovjekovne učene interpretacije rimskoga prava od ključne je važnosti bilo postojanje uređene i hijerarhizirane Crkve, uklopljene u sustav "papinske monarhije", čega u Bosni u punome smislu nije nikada ni bilo. U kasnijim vremenima (14. i 15. stoljeće) utjecaj se "učenoga" prava u raznim dijelovima Europe osjeti i u djelovanju svjetovnih administracija (poglavito onih gradskih, ali i kraljevskih), no tome nema ni traga u Bosni, kao što ni u vrelima koja se odnose na njezinu povijest do sredine 15. stoljeća nema niti traga boravku (a kamoli djelovanju) kojega obrazovanog pravnika. To je li koji od pripadnika franjevačke Bosanske vikarije tijekom druge polovice 14. i u 15. stoljeću mogao steći ovakve ili onakve predodžbe o kanonskome, pa onda i civilnom pravu (zasad se, međutim, ne zna ni za jednoga "doktora prava" među njima), u kontekstu o kojemu je ovdje riječ ne znači ama baš ništa!

36 D. Lovrenović, Na klizištu povijesti..., str. 458. Ovakvih i sličnih mjesta u knjizi ima bezbroj. Namjerno neprecizni izričaj iz privilegija Tvrtka I. Dubrovčanima (koji je u historiografiji doduše izazvao velike prijepore) prema kojemu se u kraljevo ime tvrdi "idoh' v' sr'b'skujo zemljo ... i tamo š'd'šu mi vjenčan' b'ih'" (F. Miklosich, Monumenta Serbica..., str. 187, br. CLXXXI, 10. travnja 1378.), a što bi se moglo prevesti "išao sam u srpsku zemlju ... i tamo išavši bih ovjenčan" (a što ima smisla ako se želi ustvrditi da se dogodilo nešto što se zapravo nije dogodilo), D. Lovrenović naziva ni manje ni više no "itinerarom" (dakle: planom ili programom putovanja, koji uobičajeno donosi postaje toga putovanja) (D. Lovrenović, Na klizištu povijesti..., str. 621). 
Sve ovo zapravo ukazuje na "bazično i fundamentalno šarlatanstvo" autora - raščlamba njegove knjige iznijela je na vidjelo beskrajnu naraciju zbivanja $s$ kraja 14 . i najvećega dijela 15 . stoljeća nastalu kompiliranjem činjenica i "činjenica" povađenih (gotovo) isključivo iz objavljenih vrela (već sam naznačio značenje činjenice da autor koji želi pisati o odnosima Bosanskoga i Ugarsko-Hrvatskoga Kraljevstva nije istraživao u najvažnijoj arhivskoj instituciji u kojoj se čuvaju tisuće i tisuće neobjavljenih dokumenata, od kojih barem nekoliko desetina predstavlja ključni element za razumijevanje tih odnosa). Lovrenović doduše obilato citira dokumente iz dubrovačkoga arhiva, ali je nevolja s tim citatima što se u najvećem broju slučajeva radi o dokumentima koji su po nekoliko puta citirani u starijoj literaturi, a on sam ne daje njihovo novo tumačenje, pa se može zaključiti da je riječ o triku koji bi mu trebao priskrbiti legitimitet "istraživača", što se pokazalo uspješnim, barem kada je riječ o prikazivačima njegova djela, Esadu Kurtoviću i Amiru Kliki. Svaku činjenicu i "činjenicu" autor je prokomentirao slijedeći suvremene, ovodobne, postavke (najočitija je ona o "političkoj neovisnosti" i čak "suverenitetu" kao najvišim političkim vrijednostima), a ne one koje su proizašle kao rezultat istraživanja, što rezultira gotovo pa fascinantnim nepoznavanjem i nerazumijevanjem svijeta o kojemu piše (iz cjeline njegova djela jasno proizlazi zaključak da autor prošlost ne vidi kao "stranu zemlju" s drugačijim shvaćanjima, običajima itd.). Na temelju vlastite "narativne šume" (u kojoj se zagubio) zamislio je izvesti teorijske postavke, no kako mu naracija nema organske veze $s$ idejama koje je (očito) sklopio u konstrukciju i prije no što je počeo raditi, ostao je pri kompiliranju stajališta iz širokoga spektra sekundarne literature koja i najdoslovnije nema (i ne može imati) bilo kakvu izravnu vezu sa srednjovjekovnom Bosnom (raščlanjivati sve promašene komparacije u koje se upušta nema nikakva smisla, jer to nikamo ne vodi). Ni one temeljne premise od kojih sam kreće nisu u kasnijem razlaganju razrađene niti su našle mjesto u njegovoj konstrukciji "modela" (ako u ovome slučaju uopće može biti riječi o tome), pa se čini da je posve zaboravio kako na početku svoga djela ispravno tvrdi "da značaj teme osmotren iz mađarskog ni izdaleka ne odgovara njezinu značaju sagledanom iz bosanskog ugla", odnosno da "značaj odnosa s Ugarskom kada je o Bosni riječ jedva se može precijeniti". ${ }^{37}$ Ako ovako postavljanje početnih premisa ne vodi ka zaključku o nekoj vrsti hijerarhijskoga odnosa između dvaju društvenih/političkih zajednica o kojima je riječ, onda nešto nije u redu s logikom onoga tko piše.

Je li dakle sve ovo "bazično i fundamentalno šarlatanstvo"? Odgovor na to retoričko pitanje ne može biti jednostavan i jednoznačan - "prisvajanje" Kantorowiczeve misli, "bazično identično i fundamentalno različito", kao i "itinerar" sastavljen od "išao sam ... i išavši bio", jesu doista elementi šarlatanstva, no za cjelovitu prosudbu ovoga, kao i svakoga drugog povjesničarskog djela, valja uzeti u obzir i ono što se naziva "autorski meta-narativ". Riječ je o onome dijelu 
povjesničarskoga pothvata koji ostaje prikriven ispod naracije i teorijskih postavki, a koji se može označiti kao "potraga za smislom", ili u nešto tvrđoj varijanti "proizvodnja smisla", u čemu kao povjesničari uvijek vrlo aktivno (što ne znači i uspješno ili učinkovito) sudjelujemo. Treba biti beskrajno naivan te pomisliti da se toga možemo riješiti. Jedino što kao misleće jedinke možemo uraditi jest nastojati "kontrolirati štetu", odnosno nastojati da nam "potraga za smislom" ili njegova "proizvodnja" ne zaklone previše pogled na izgubljenu prošlu stvarnost koju istražujemo i objašnjavamo (gradacija uspjeha u tome tvori razliku između onih koji se onda mogu nazivati "znanstvenicima", i onih koji nastupaju kao "pamfletisti"). Taj dakle element, "metanarativa" kao "proizvodnje smisla", u djelu D. Lovrenovića nije moguće razumjeti ne uzimajući u obzir njegovu društvenu poziciju. On, naime, nije "obični" akademski povjesničar zagubljen u starim papirima i pergamenama (vidjelo se da s njima teško da je i došao u dodir).

Naprotiv, D. Lovrenović je istaknuta figura u svijetu koji svoje središte ima u Sarajevu i koji kao (društveno konstruirana) stvarnost funkcionira na jednom dijelu teritorija države Bosne i Hercegovine. Ne samo da vrlo aktivno sudjeluje u prostoru "javnoga govora", nego je zauzimao ili zauzima društveno važne pozicije (bio je zamjenik ministra, član je Akademije nauka i umjetnost $\mathrm{BiH}$, sudionik važnih ritualnih čina javnoga života sredine kojoj pripada itd. itd.). Sve je to D. Lovrenović ponajprije zahvaljujući činjenici da ga se percipira i doživljava kao "antinacionalistu", posebice kritičnoga spram nacionalne zajednice kojoj je (valjda) pripadao po rođenju i odgoju sve dok se toga pripadanja nije i javno odrekao. ${ }^{38}$ Stvaranje takve slike o sebi vidi se izrazito jasno i na stranicama knjige $\mathrm{Na}$ klizištu povijesti, ${ }^{39}$ kao uostalom i u drugim

38 Vidi: http://www.oslobodjenje.ba/vijesti/bih/dubravko-lovrenovic-ja-sam-rijesio-za-sebe-hrvatsko-pitanje-bosanac-sam (20. 5. 2015.). Ovdje me javno oćitovanje ovoga tipa zanima samo u kontekstu produkcije "javne slike o samome sebi", pri čemu je iz samoga izričaja jasno kako je autor izjave prije toga bio "Hrvat". No, D. Lovrenović ide i korak dalje te svoj "osobni recept za rješenje hrvatskoga pitanja" želi, upravo iz svoje pozicije "autoritativnoga povjesničara", nametnuti i drugima: "Bili smo Bosanci i Hercegovci, postali smo Hrvati, sada je ponovo red da postanemo ono što smo oduvijek i bili". Vidi: http://24sata.info//vijesti/intervju/198149-dubravko-lovrenovic-hrvatstvo-u-bih-je-fikcija.html\#sthash.kqI8SZIB.dpuf (20. 5. 2015.).

39 Savršeno jasan signal u tome smislu, posve izvan misaonoga konteksta u kojem funkcionira, predstavlja autorovo stajalište iskazano na samome početku knjige, tamo gdje definira svoj pristup problemu kojim će se baviti. "Daleko iznad ovog (a referira se na tekst o 'fantomskom bogumilstvu' i pristup u kojem su 'povijesni fakti ništa, interpretacija je sve' - op. M.A.) je promišljanje zagrebačkog profesora Ive Goldsteina, koji intelektualno i znanstveno superiornom metodom sahranjuje velikohrvatski mit o Hrvatskoj do Drine" (D. Lovrenović, Na klizištu povijesti..., str. 5, bilj. 22 - naglašeno u izvorniku). "Velikohrvatski mit" nije ni trebalo sahranjivati jer se sam od sebe urušio u sudaru sa stvarnošću, pa je danas tek "radioaktivni ideološki otpad" pravaštva ("radioaktivni" je jer se polako raspada), ali je zanimljivo svakako ukazati na činjenicu da je "zagrebački profesor" bio član povjerenstva na obrani doktorata D. Lovrenovića, a onda i recenzent knjige nastale iz toga doktorata (ne mogu se a ne prisjetiti ovdje čuvene crnogorske izre- 
njegovim pisanim javnim istupima. ${ }^{40}$ D. Lovrenović je, dakle, izraziti "antinacionalist" poglavito kritičan prema hrvatskome nacionalizmu, nešto manje prema bošnjačkome i ponajmanje prema srpskome. No, kao i većina "antinacionalista" on ne razumije da je nacionalizam temeljna misaona shema europske modernosti te je kao takav sastavni i neizbježni dio našega mentalnog krajolika ${ }^{41}$ pa je samo pitanje kako vrjednujemo koji nacionalizam. I tu konačno dolazimo do merituma problema. D. Lovrenović nije ni hrvatski, ni bošnjački (naravno ni srpski) nacionalist, on je bosanski nacionalist. Cijelo je njegovo djelo jasna eksplikacija toga nacionalizma za koji je sam autor duboko uvjeren da je veoma pozitivna stvar, za razliku od "partikularnih nacionalizama" koji "produbljuju mentalnu i političku disoluciju među pripadnicima zajedničkog duhovnopovijesnog prostora" (a to je mitska "Bosna" kao fizički okvir njegova nacionalizma), uslijed čega "šanse za konstituiranjem u modernu državu sa zajamčenim osobnim i nacionalnim pravima svakim danom sve više kopne".42 Tome se, vođen očito u svojoj viziji isključivo plemenitim porivima "društvene koristi" i želje za "povijesnom istinom" (valjda ne primjećujući kako to, barem u njegovu slučaju, donosi i znatne materijalne koristi, vrlo čvrsto povezane sa simboličkim kapitalom koji skuplja kroza svoj "antinacionalizam"), odlučio usprotiviti $\mathrm{D}$. Lovrenović razotkrivajući lažnu mitološku sliku prošlosti koju proizvode "nacionalisti" i suprotstaviti joj sliku samostalne, suverene srednjovjekovne Bosne, zemlje neobične vjerske tolerancije, koja bi danas trebala poslužiti kao nadahnuće onima koji društveno djeluju. $\mathrm{Na}$ taj način on stvara "patriotsku historiografiju" po modelu 19. stoljeća, iz vremena oblikovanja modernih nacija kada je i stvorena profesionalna akademska historiografija (koja se, naravno, u međuvremenu stubokom

ke: "Ja tebi vojvodo, a ti meni serdare ... a obojica znamo ...", koja tako plastično opisuje o čemu je tu riječ, poglavito pročita li se izvadak iz recenzije "zagrebačkoga profesora" otisnut na ovitku knjige). Iz ovoga očišta postaje puno jasnije zašto je D. Lovrenović osjećao potrebu ubaciti u svoje djelo nebulozne "činjenice" prikupljene kod N. Milaša. One dokazuju kako on jasno raspoznaje hrvatski/katolički nacionalizam "na djelu" u negiranju pravoslavne tradicije u Dalmaciji (jest da toga pravoslavlja u srednjemu vijeku tamo nije ni bilo, ali što je to u usporedbi s dokazivanjem vlastitoga "antinacionalizma").

40 Vidi primjerice javnu polemiku što su je D. Lovrenović i Ivo Lučić vodili na stranicama mostarskoga časopisa Status (14 - 2010., 15 - 2011. i 16 - 2013.).

41 Bjelodano je to već poodavno pokazala i dokazala izvan svake razumne dvojbe LiAH Greenfeld, "Nationalism and the mind", u: Nations and Nationalism, 11/3, London, 2005., gdje su sumirani i rezultati autoričinih ranijih djela iz 1992. (Nationalism: Five Roads to Modernity) i 2001. (The Spirit of Capitalism: Nationalism and Economic Growth). Usporedi međutim: Dušan Kecmanović, "Nationalism and Mental Health: A Critique of Greenfeld's Recent Views of Nationalism", u: Nationalism and Ethnic Politics, 13, (Routledge) 2007., za kritiku autoričinih zaključaka o korelaciji između društvene anomije (kao stanja izazvanoga modernim, nacionalističkim svjetonazorom) i učestalosti psihičkih i mentalnih poremećaja. Za pojam mentalnoga krajolika i utjecaj koji u njegovoj izgradnji ima društveno okruženje vidi: Eviatar Zerubavel, Social Mindscapes: An Invitation to Cognitive Sociology, Harvard University Press, Cambridge (MA), 1997.

42 Usp. D. Lovrenović, Na klizištu povijesti..., str. 13, bilj. 72. 
izmijenila), nesvjestan svega što je već ugrađeno u lokalnu varijantu modela kojim se koristi. Tu se, između ostaloga, mogu naći ostatci predmodernih shvaćanja mileta s franjevačkom zajednicom kao elitom i predvodnikom (nije slučajno što D. Lovrenović svoje radove vrlo često objavljuje na stranicama časopisa Bosna franciscana, koji još uvijek funkcionira kao "kovčežić sve mudrosti" - malo "filozofije", malo "povijesti", malo "književnosti" i svega ostalog potrebnog za "duhovnu hranu" cijeloga "kršćanskog stada" - mileta); hegelovsko shvaćanje "države" kao konačnoga smisla povijesnoga razvoja. Iz toga shvaćanja izvedene mitologije "nacionalnoga oslobođenja" od "tuđinske vlasti", što je bio inače utemeljiteljski politički mit prve Jugoslavije (odatle dolazi prijemčivost za pseudo-znanost Dvornikovića i diskurs srpske historiografije); klasne reinterpretacije toga mita po nacrtu Milovana Đilasa, koja je obilježila historiografiju socijalističke Jugoslavije (najjasnije se to vidi po prihvaćanju stajališta Nade Klaić). Lovrenovićeva se povijesna "bosanska arkadija" dakle razlikuje od one povijesne "bošnjačke arkadije" što su je oblikovale generacije bošnjačkih povjesničara, počevši s onom koja je promovirana zajedno $s$ političkim priznanjem postojanja muslimanske (danas: bošnjačke) nacije potkraj 60-ih godina 20. stoljeća. ${ }^{43}$ Njihov je ideal otomanski Bosanski
Pašaluk kao nacrt bošnjačke nacionalne države, a ta se razlika uglavnom svodi na tumačenje odnosa i pozicije vjerskih ("narodnih") zajednica. Dok "bosanska arkadija" podrazumijeva jednu vrst "bratstva i jedinstva", dotle "bošnjačka arkadija" podrazumijeva postojanje "temeljnoga naroda" (naravno onoga bošnjačkog).

Kao i svaki pravi neosviješteni nacionalist D. Lovrenović pati od viška patetike i treba posebnu poetiku kako bi nadomjestio nedostatak razumnih argumenata, pa odatle silna potreba za izričajima s jakim (ali često i besmislenim metaforama) poput onih o autorima koji su "znanstvenu metodu bacili pod noge političkog i nacionalnog pravovjerja", o "prevlasti ideološkog kiča, s historiografijom često kao bolesničkom štakom dnevne politike", ${ }^{44}$ ili o "ispisivanju 'kataloga' konfesionalno-političkih psovki" što je onda stvaralo "verbalni 'barometar'" na kojem se "precizno ogledao rast i pad pritiska u ugarsko-bosanskoj feudalnoj 'trakavici'". 45

Da zaključim dakle, D. Lovrenović napisao je lošu knjigu koja je ostala nedorečena, na sredini između povjesničarskoga uratka (nedovršenoga jer svoj predmet nije istražio kako treba) i političkoga pamfleta (prikrivenoga i ostavljenoga na razini implikacija), pa nije ni jedno ni drugo. Kao povjesničar nije uspio integrirati naraciju

43 Za ogledni primjer te "historiografske" produkcije može se uzeti: Mustafa Imamović, Historija Bošnjaka, Bošnjačka zajednica kulture "Preporod", Sarajevo, 1997. Ta se produkcija, inače, po svemu ugleda i svojim nutarnjim značajkama (poglavito pristupom povijesnoj materiji u "patriotskom duhu") prati onu produkciju što je tijekom 20. stoljeća nastajala u sklopu "beogradske škole" pa se slobodno može govoriti o "beogradsko-sarajevskoj povjesničarskoj školi", a kojoj po svemu pripada i D. Lovrenović.

44 D. Lovrenović, Na klizištu povijesti..., str. 14.

45 Isto, str. 589. 
i teorijski segment svoga djela, a kao pamfletist, "nacionalni djelatnik", nije uspio na razgovijetan i jezgrovit način "progurati" svoju temeljnu političku agendu, onu "(građanskog) bosanskog nacionalizma" kojemu je nastojao osigurati povijesnu utemeljenost. U jednu riječ, knjiga je gotovo pa beskorisna (kako se može razabrati, čak ni naraciju nije moguće koristiti bez provjere) te je pravo pitanje zašto je i po kojim kriterijima uložen popriličan novac u njezino izdavanje.

Ostavljajući dakle otužnu sliku današnje bosansko-hercegovačke, ali i hrvatske stvarnosti u kojima ima dovoljno volje da se (relativno) velika sredstva "ulupaju" u super-luksuzno izdanje knjige koja je savršena eksplikacija "bazičnog fundamentalnog šarlatanstva", valja se okrenuti srednjovjekovnome svijetu i ogledati što se eventualno novoga može reći o odnosu Bosne (Banovine i od 1377. godine Kraljevstva) spram UgarskoHrvatskoga Kraljevstva. U onome što sam o tomu prije napisao nema puno toga što bih mijenjao te to ovdje ne mislim opširnije ponavljati, pa ću $s$ pozivom na nekoliko dosad u ovome kontekstu nekorištenih dokumenata i drugačijim čitanjem onih odavno poznatih pokušati izoštriti već ranije ocrtanu sliku. U tome smislu pokušat ću, u mjeri u kojoj to dopuštaju sačuvana i dostupna vrela, utvrditi kako su izgledale mentalne sheme ("slike u glavama"46) koje su se odnosile na oblike organizacije društvenih zajednica i njihovu eksplikaciju do razine oblikovanja političkih zemljovida kod aktera srednjovjekovnih zbivanja - od kraljevskih dvorova do svijeta velikaša i njihovih "familijara", dakle onoga društvenog sloja čije djelovanje, pa onda i predodžbe (koje su nadilazile obzor lokalnih zajednica) na temelju kojih se djelovalo, mogu koliko-toliko biti istraženi.

Za polaznu ću poziciju uzeti već iznesenu temeljnu tezu da je Bosna (i kao Banovina i kao Kraljevstvo) bila integralnim dijelom složene političke tvorbe za koju mi se još uvijek najzgodnijom čini oznaka Archiregnum Hungaricum. Riječ je o sustavu političkih veza koji je osiguravao hegemoniju i ulogu "središta" izvorno ugarskim kraljevima i njihovu dvoru na širokome (i glede granica promjenljivom) prostoru srednje-istočne i jugo-istočne Europe, obilježenom etničkim, vjerskim i kulturnim šarenilom. ${ }^{47} \mathrm{Taj}$ je sustav funkcionirao u dugome razdoblju od preko četiri stoljeća (začet-

46 Pojam "slike u glavama" odavno je u literaturu uveo Walter Lippmann, a koristi ga kao sinonim za "stereotipe" Klaus Rot, Slike u glavama, Čigoja štampa, Beograd, 2000. uz objašnjenje (str. 260) koje se ovdje može uzeti kao dostatno: "stereotipi su kognitivne formule, uvrežena uverenja koja služe asimilovanju okruženja i snalaženju u životu. To su istorijski promenljive, ali ipak prilično stabilne svakodnevne kategorizacije, tipizacije okruženja; međutim, pošto utiču na ponašanje, one imaju i povratno dejstvo na stvarnost, one mogu da utiču na stvarnost i da je stvaraju". O "slikama u glavama/stereotipima" kao kognitivnom oruđu vidi i tekstove u: CRAIG McGARTY et al. (ur.), Stereotypes as Explanations. The foramtion of meaningful beliefs about social groups, Cambridge University Press, Cambridge, 2004.

47 Etničko i kulturno šarenilo jasno se razabire iz raščlambe predočene u: JÁNOs M. BAK, "A Kingdom of Many Languages: The Case of Medieval Hungary", u: Isti, Studying 
ci mu se gube u "mračnome" dobu, za povjesničare neosvijetljenom zbog gotovo posvemašnjega nedostatka sačuvane pisane dokumentacije, odakle i proizlazi kronološka nepreciznost), a koji je konačni krah doživio porazom na Mohačkome polju 1526. godine u srazu s vojnom silom otomanskoga sultana. Tijekom toga vremena sustav se konfigurirao (velikim dijelom i zbog naznačenoga etničkog, vjerskog i kulturnog šarenila) u mozaik političkih jedinica različita statusa (pod zbirnim nazivom "zemlje", ili kasnije regna) i različite naravi veza sa "središtem" - od "jezgrenoga" područja Ugarske kojim je kralj izravno vladao, preko "zemalja" ili regna kojima je upravljao uglavnom iz središta odaslani kraljevski zastupnik (Hrvatska, Transilvanija) ili je tu ulogu preuzela lokalna dinastija koja je svoj položaj legitimirala dinastičkim vezama sa "središtem" (Bosna), do "zemalja"/država koje su tek nepotpuno ili povremeno bile vezane uz to "središste" čuvajući najvećim dijelom svoje izvorne organizacijske i upravljačke strukture (Srbija, Bugarska, Vlaška, Moldavija).

U nastojanju da se razjasni i precizira status tih jedinica (barem što se tiče stanja kakvo vlada u kasnome sred- njem vijeku, 14. i 15. stoljeću) čini se valjanim osloniti se za početnu poziciju daljnje raščlambe na ideju koju je svojedobno (još 1902. godine) artikulirao Otto Hintze, razlikujući provincije modernih unitarnih $\mathrm{dr}$ žava kojima se vlada na isti način iz političkoga središta, od "provincija staroga režima" s njihovim zasebnim predstavničkim tijelima i autonomnim "guvernerima", koje su "bile svojevrsne male države, a veze koje su ih međusobno povezivale nisu daleko nadilazile jednostavnu personalnu uniju; u gospodarskome, pravnome i smislu upravljanja one su bile u nekoj mjeri prepuštene same sebi i jasno odvojene jedne od drugih". ${ }^{4}$

Pojam pak "središta" ovdje se uzima ne u doslovnom fizičkom značenju, nego u onome društvenom kako su ga definirali Edward Shills i Clifford Geertz kao "fenomen područja vrijednosti i vjerovanja. To je središte sustava simbola, vrijednosti i vjerovanja koji upravljaju društvom... Središte je također fenomen područja djelovanja. To je struktura djelovanja, uloga i osoba unutar mreže institucija. Upravo se kroz te uloge utjelovljuju i promiču središnje vrijednosti i vjerovanja". ${ }^{49}$ Tako shvaćena "središta" se "sastoje od

Medieval Rulers and Their Subjects: Central Europe and Beyond, Ashgate, Surrey, 2010. Valja svakako uz ovo upozoriti da János Bak raščlanjuje tek jezični mozaik na prostoru Ugarsko-Hrvatskoga Kraljevstva, što se ne može izravno prevoditi u kategoriju etničnosti, ali bi svaka daljnja raščlamba toga problema zahtijevala tekst znatno veći i od ovoga koji čitatelj ima pred sobom. Dovoljno je za ovu prigodu samo naznačiti da je kulturni i etnički mozaik bio znatno složeniji od onoga lingvističkoga, dobrim dijelom i zbog vjerskih razlika.

48 Отто Hintze, "The Formation of States and Constitutional Development: A Study in History and Politics", u: Felix Calibri (ur.), The Historical Essays of Otto Hintze, Oxford University Press, New York, 1975., str. 173.

49 Edward Shils, The Constitution of Society, University of Chicago Press, Chicago, 1982., str. 93-94. Usp. također i M. Ančić, "Dva teksta iz sredine 14. stoljeća: Prilog poznava- 
točke ili točaka u društvu iz kojih dolaze vodeće ideje zajedno s njihovim vodećim institucijama da bi stvorile arenu u kojoj će se razvijati događaji koji će najvitalnije utjecati na živote članova toga društva", a tvore ih "i vladajuća elita i skup simboličkih oblika koji konstatiraju činjenicu da ta elita zapravo vlada". Pripadnici elite "opravdavaju svoje postojanje i uređuju svoje činove preko zbirki priča, ceremonija, ordena, formalnosti i svega što su naslijedili", što sve "označava središte kao središte i daje onome što se u njemu zbiva auru ne samo važnosti, nego i auru koja je na neki čudan način povezana $s$ načinom na koji je izgrađen svijet". 50

Sustav, pak, označen kao Archiregnum Hungaricum teško je nazvati modernim pojmom "država", od kojega eu- ropski povjesničari srednjega vijeka nerijetko (ali ipak bezrazložno) zaziru te ga nastoje izbjeći..$^{51}$ No, uzimajući u obzir sve primjedbe glede uporabe toga pojma, čini se doista ispravnim kvalificirati ga na određen način te ću stoga nadalje, pristajući uz ideje što ih je izložio Pierre Bourdieu, ${ }^{52}$ koristiti izraz "dinastička (nad)država", i to bez navodnih znakova. Njihovo uklanjanje proizlazi ponajprije iz toga što su već i suvremenici bili jasno svjesni postojanja toga specifičnog i složenog oblika društvene organizacije. Dostatno je u tome smislu samo upozoriti na primjer iz početka 13. stoljeća kada je kralj Emerik (prema izričaju što ga je uporabio papinski legat Ivan de Casamaris) garantirao slobodan prolazak na papinski dvor bugarskim izaslanicima "cijelim Ugarskim Kraljevstvom (i zemljama) njegovih srod-

nju 'društvenog znanja' Hrvatskog Kraljevstva", u: Starohrvatska prosvjeta, III. serija, br. 40, Split, 2013., str. 184.

50 Clifford Geertz, "Središta, kraljevi i karizma: Razmišljanja o simbolici moći", u: Isti, Lokalno znanje (izv. Local knowledge, 1983.), AGM, Zagreb, 2010., str. 154, 156. Kako se ove generalne ideje primjenjuju na raščlambu srednjovjekovne stvarnosti može se razabrati iz: Gerald E. Aymler, "Centre and Locality: The Nature of Power Elites", u: Wolfgang Reinhard (ur.), Power Elites and State Building, Clarendon Press, Oxford, 1996., te JACQues Le Goff, "Il re nell'Occidente medievale: i caratteri originali", u: Isti, Il re nell'Occidente medievale, Editori Laterza, Bari, 2008., 23-49 (izvorno je tekst 1993. godine bio objavljen na engleskome jeziku, potom u francuskoj verziji kao "Le Roi dans l'Occident médiéval: caractèrs originaux" 2004. godine; talijanska je verzija prijevod s francuskoga).

51 Vidi primjerice raspravu o uporabi pojma "država" za opis srednjovjekovne stvarnosti što su je na stranicama časopisa Journal of Historical Sociology $(16$ - 2003. i 17 - 2004.) vodili Reece Davies i Susan Reynolds. Primjer povjesničara koji izbjegava taj pojam za opis političke stvarnosti 14. i 15. stoljeća u Europi jest JoHn WaTts, The Making of Polities: Europe, 1300-1500, Cambridge UP, Cambridge, 2009. Kao suprotan primjer može poslužiti Bernard Guenée, States and Rulers in Later Medieval Europe (izv. L'Occident aux XIVe et XVe siècles. Les États, 1981.), Blackwell, Oxford, 1985. Širi kontekst unutar kojega se uporaba pojma "država" za političke tvorbe srednjega vijeka ukazuje opravdanim ocrtavaju TED Luelen, Uvod u političku antropologiju (izv. Ted C. Lewellen, Political Anthropology: An Introduction, 1992.), Gradina, Cačak - Beograd, 2001., str. 44-61, te Donald V. Kurtz, Political Anthropology. Paradigms and Power, Westview Press, Boulder, 2001., str. 169-188.

52 Pierre Bourdieu, "From the King's House to the Reason of State: A Model of the Genesis of the Bureaucratic Field", u: Constellations, 11(1)/2004. Na ovdje izložene ideje još ću se tijekom razlaganja vraćati. 
nika i prijatelja". ${ }^{53}$ Kakav je dakle bio položaj Bosne u tome sustavu koji se spleo oko "krune sv. Stjepana" kao simbola dinastičke (nad)države? $\mathrm{Na}$ razini pripovijesti, "priča" koje opravdavaju i uređuju odnose i postupke, dinastija Kotromanića, koja je neprekidno vladala Bosnom do 1463. godine, svoju je legitimaciju gradila na (stvarnom ili izmišljenom) instaliranju "Kotromana Gota" (Cotrumano Gotto), rođaka (parente) kraljevske dinastije Arpadovića, za poglavara zemlje. Pripovijest o "Kotromanu Gotu" sačuvana je za moderne povjesničare tek u dvije posredne interpretacije - jedna je ona iz (ovdje već spominjane) izgubljene Povijesti (Istorije) Kotromanića, kako ju je u svome djelu prenio Mavro Orbini, a druga, vrlo kratka, verzija je ona koju je dubrovački poklisar trebao izdeklamirati pred bosanskim kraljem Tvrtkom II. u svibnju 1432., podsjećajući ga na odnos njegovih predaka i Dubrovni$\mathrm{ka} .{ }^{54}$ Obje su verzije skladne te se čak može naslutiti da ono što je poklisar trebao ispripovijedati potječe iz izgu- bljene Povijesti, koja je u Dubrovniku bila poznata posve izvjesno početkom 15. stoljeća, što jasno signalizira da nije riječ o nekom ezoteričnom znanju nego naprotiv o naširoko poznatome sklopu činjenica i zamisli. Pri tome valja naglasiti kako su poznavanje genealogije bosanske vladajuće kuće Dubrovčani pokazali u vrijeme teških nutarnjih sukoba u samoj Bosni i smjene kralja Ostoje s prijestola 1404. godine, kada su hercegu Hrvoju potkraj 1403. godine pisali o tomu kako kod njih boravi jedan od Kotromanića vrjedniji kraljevskoga naslova no aktualni kralj Ostoja. ${ }^{55}$ Sto se pak tiče vjerodostojnosti te "pripovijesti" kako je poznajemo u skraćenom obliku teško se može naći razlog za sumnju u to da u njoj postoje elementi koji imaju realno ishodište u stvarnim događajima druge polovice 12 . i početka 13. stoljeća, no to ipak, zbog nedostatka vrela, mora ostati još uvijek otvoreno pitanje pa stoga i nisam preciznije definirao vremenski raspon vladavine Kotromanića. ${ }^{56}$ Za prosudbu važnosti ove "pripovijesti" valja

53 Izričaj per totum regnum Ungarie et amicitie ipsius et parentele uporabio je Ivan de Casemaris u pismu upućenom na papinsku kuriju 10. lipnja 1203. - vidi: TADIJA SMIČıKLAS et al. (prir.), Diplomatički zbornik kraljevine Hrvatske, Dalmacije i Slavonije (dalje: DZ), III., JAZU; Zagreb, 1905., str. 36, br. 32. Za datum vidi M. ANČıć, "Bilinopoljska abjuracija...", str. 24, bilj. 18.

54 Vidi M. AnčIĆ, Na rubu Zapada..., str. 20-21.

55 Jószef Gelcich - Lajos Thallóczy (prir.), Diplomatarium relationum reipublicae Ragusanae cum regno Hungariae, MTA, Budapest, 1887., str. 134, br. 95, 16. 11. 1403.: nui ve recordemo che sono degli Chotromanichi de meliori et plu discreti de Hostoia ... de quelli, che sono in Bossina nui non potemo havere cossi bon noticia, come vui. Ma de quello chi nui ve possemo recordar et testificar qui in Ragusa e uno el qual ha nome Pavel Radissich.

56 Svakako je indikativno kako se u "patriotskoj historiografiji" (onoj "beogradsko-sarajevske škole") nerado govori o "njemačkome" podrijetlu vladajuće dinastije i srodstvu s dinastijom Arpadovića. Takvo bi podrijetlo značilo stigmu "tuđinskoga" elementa. U tome je kontekstu onda razumljivo zašto se "pripovijest" (očito veoma važna u samodefiniranju dinastije, ali i u objašnjavanju odnosa s ugarsko-hrvatskim vladarima) uopće ne pojavljuje u Lovrenovićevoj knjizi te on čak i izrijekom tvrdi da Kotromanići nisu imali nikakve dinastičke veze s Arpadovićima (D. Lovrenović, Na klizištu povijesti..., str. 55). S druge strane Lovrenović inzistira na dinastičkim vezama s Nemanjićima, 
svakako naglasiti kako je dinastička država kao tip organizacije počivala na premisi da je vladar (kralj, u slučaju Bosne pak ban) zapravo "glava kućanstva", a područje je njegova vladanja bilo izjednačeno s "kućanstvom" (oikos) koje je on, rabeći tu dostupne resurse (u prvome redu simbolički kapital stvoren na ideji plemenitosti povezanoj $s$ genealogijom) uspostavio kao administraciju (oikonomia) nad određenim teritorijem. ${ }^{57}$ Transgeneracijski prijenos prava u tome se sustavu temeljio na biološkoj reprodukciji "vladajuće kuće" pa upravo iz toga konteksta dolazi važnost genealoške dimenzije dinastije Kotromanića kao nasljednika "Kotromana Gota" i nje- zine rodbinske povezanosti s vladajućom ugarskom dinastijom.

Legitimacijsko ishodište vlasti Kotromanića u vezi s dinastijom Arpadovića vraća ovu raspravu na stanje u 12 . stoljeću te u tome kontekstu traži barem osvrt na pitanje kako je i na koji način oblikovan, reproduciran i kroz tu reprodukciju odnosa tijekom tri stoljeća mijenjan njihov sadržaj. Pri tomu valja poći od onoga sklopa odnosa koji su koliko-toliko pouzdano posvjedočeni sačuvanim izvornim materijalom u mjeri koja dopušta sigurnije zaključivanje. Takvu polaznu poziciju tvori stanje kakvo je vladalo od sredine 13 . stoljeća, kada je Bosna, iako pod izrav-

postupajući pri tomu s mnogo manje opreza od primjerice Sime Ćirkovića, koji s velikom rezervom uzima pozivanje Tvrtka I. iz 1378. godine na rodbinske veze sa srpskom dinastijom (usp. Sima Ćirković, "Sugubi venac. Prilog istoriji kraljevstva u Bosni", u: Isti, Rabotnici, Vojnici, Duhovnici, Equilibrium, Beograd, 1997., str. 280). Lovrenović vidi takvo inzistiranje čak i tamo gdje ga uopće nema pa tako primjerice tvrdi: "Pravni okvir za ustupanje Kotora određen je bio Tvrtkovim rodbinskim vezama sa svetorodnom dinastijom Nemanjića, što kralj nije propustio istaknuti potvrđujući 23. VIII. 1385. privilegije mletačkim trgovcima" (D. Lovrenović, Na klizištu povijesti..., str. 36). Dokument, međutim, na koji se poziva ne pruža nikakve temelje za takvu tvrdnju, jer se u jedinoj rečenici u kojoj se govori o kraljevu pravu na Kotor najizravnije i jedino poziva na "milost" njegove "sestre ugarske kraljice Elizabete" koja mu je grad prepustila (...quod cum per gratiam largiflue dedi disposicionis et preclarissime sororis nostre domine regine Ungarie civitas predecessorum nostrorum Catharensis feliciter ad manus nostre maiestatis perpetualiter pervenit - ŠIME LJUBIĆ, Listine o odnošajih između južnoga slavenstva i Mletačke Republike, IV., JAZU, Zagreb, 1874., str. 221, br. CCCXV; predecessorum latinskoga izričaja svoju paralelu ima u "niegovjeh' prjegnjeh'" iz isprava pisanih hrvatskim jezikom - primjerice: F. Miklosich, Monumenta Serbica..., str. 210, br. CXCVII, 9. 4. 1389. - što je, pak, bitno različito od izričaja iz privilegija izdanog 1378. godine, gdje se spominje "prjestol' moih' prjeroditel', gospode sr'bske". Usp. Isto, str. 187, br. CLXXXI, 10. 4. 1378.). Pripovijest nije našla mjesta ni u djelu Esada Kurtovića, koji je pošao tragom svih mogućih dubrovačkih vrela što potječu iz prvih desetljeća 15 . stoljeća a odnose se na Bosnu, te je u tome kontekstu posvetio pozornost i dubrovačkome poznavanju genealogije Kotromanića i citirao isto ono pismo iz kojega je ovdje reproduciran izvadak (usp. Esad Kurtović, Veliki vojvoda bosanski Sandalj Hranić Kosača, Institut za istoriju, Sarajevo, 2009., str. 118-119).

57 P. Bourdieu, "From the King's House...", str. 17. Kategorija "kućanstva" (maison) kod P. Bourdieua korespondira s kategorijom oikos/das ganze Haus/casa come complesso kako ga razmatra i razvija, razlažući predmodernu (moralnu) europsku ekonomiju, ОтTo BRUNNER, "La 'casa come complesso' e l'antica 'economica' europea", u: Isti, Per una nuova storia costituzionale e sociale (izv. Neue Wege der Verfassungs- und Sozialgeschichte, 1980.), Vita e Pensiero, Milano, 2000., str. 133-164, iako se onaj prvi ne poziva na ovoga drugog. 
nom vlašću i upravom domaće dinastije, bila uklopljena u (ponekad tako nazivani) "Slavenski dukat" Rostislava Mihailoviča. Taj je, uz područje pod vlašću bosanskoga bana, obuhvaćao široki južni pojas drinsko-savsko-dunavskoga interamnija te bi se $s$ puno prava moglo zaključiti da je tu zapravo riječ o "srpskome dukatu", na isti način na koji su pojmovi Dalmacia et Croacia, odnosno od 20-ih godina 13. stoljeća novi pojam tocius Sclauonia (uz koje je također bila vezana titula $d u x)$ označavao Hrvatsko Kraljevstvo kojim je od 1102. godine vladala dinastija Arpadovića. ${ }^{58} \mathrm{Da}$ je riječ o trajnijoj političkoj tvorbi pokazuje i to što se ona nije posve raspala ni kada je $\mathrm{u}$ jesen 1272. bio ubijen Bela, Rostislavljev sin, a njegov dukat formalno razdijeljen na banovine Usoru i Sol, Bosnu, Mačvu, Braničevo i Kučevo, jer se nešto kasnije kao ducissa de $\mathrm{Ma}$ chou et de Bosna pojavljuje Elizabeta, majka kralja Ladislava IV. Kumanca, koja je u toj funkciji upravljala i županijama požeškom i vukovskom. Ona je stvarno obnašala vlast u tim krajevima te vjerojatno dobivala stanovite prihode kao apanažu vezanu uza "slavenski dukat".59 Dio tih "zemalja"/ regna dobio je, nakon Elizabete, na upravu srpski raskralj Dragutin nakon što je svoj prijestol ustupio bratu Milutinu, pa je tim područjem upravljao još i početkom 14. stoljeća, kada je njegovu "državu" opisao u historiografiji poznati Anonim, autor jednoga od prvih opisa jugo-istočne i srednjeistočne Europe na europskome zapadu. Dragutinova "Srbija", prema tome opisu, sastojala se od tri "provincije": Bosne, Mačve i Marke (ovaj posljednji pojam se, po svemu sudeći, odnosio na Braničevo i Kučevo). ${ }^{60}$

Korijene toga (kasnije zvanoga) "srpskog dukata" svakako valja tražiti duboko u 12. stoljeću, pa bi mu prvi pisani trag po svemu sudeći trebao biti u, inače u historiografiji dobro poznatoj, ispravi u kojoj se prvi put spominje "bosanski dukat". Riječ je o naknadno pisanoj bilješci u kojoj se začetak jed-

58 Za "dukat" Rostislava Mihailoviča, zeta ugarsko-hrvatskoga kralja Bele IV., vidi: ĐurA Hardi, "O Mačvi sredinom XIII veka", u: Spomenica istorijskog arhiva "Srem", 10, Sremska Mitrovica, 2011.; Isti, "Kada je umro gospodar Mačve Rostislav Mihailovič", u: Spomenica istorijskog arhiva "Srem", 11, Sremska Mitrovica, 2012. te PÁL Engel, The Realm of St Stephen: A History of Medieval Hungary, 895-1526, I.B. Tauris, London New York, 2001., str. 106. Kao "slavenski", taj je "dukat" označen u mirovnome ugovoru sklopljenom između ugarsko-hrvatskoga kralja Stjepana V. i češkoga kralja Otakara Premysla II. 1271. godine kada je njime upravljao Rostislavljev sin Bela. (Tekst ugovora u: Gusztáv Wenzel, Codex diplomaticus Arpadianus continuatus, III., MTA, Budapest, 1862., str. 247-255, br. 152, 11. 7. 1271. U njemu je odredba prema kojoj je u mir bio uklopljen totumque ducatum Sclavonie, kao što je u popisu srodnika kralja Stjepana V. onda naveden i Bela Dux de Machow et de Bozna frater noster.)

59 Vidi posebice dokumente u DZ, VI., Zagreb, 1908., str. 421-422, br. 347, 1282. te M. AnčIć, Putanja klatna..., str. 71 bilj. 47 , koji jasno potvrđuju stvarno obavljanje vlasti. U pisanome obećanju firmanskome biskupu Filipu, papinskome legatu, izdanom 19. kolovoza 1280. Elisabet dei gracia maior regina Hungarie, ducissa de Machou et de Wazna obvezuje se in ducatibus de Machou et de Wazna, et in comitatibus de Posega et de Wolkou ceterisque comitatibus nostre iurisdictione suiectis progoniti heretike - DZ, VI., str. 357, br. 300.

60 Olgierd Górka (prir.), Anonymi descriptio Europae orientalis. "Imperium Constantinopolitanum, Albania, Serbia, Bulgaria, Ruthenia, Ungaria, Polonia, Bohemia" anno 
noga formalnog prijepora (placitum) oko zemljišnoga posjeda (koji će biti podijeljen novoutemeljenom samostanu) datira zasjedanjem kralja i njegova "vijeća" u Ostrogonu, kojom je prigodom (navodi se u dokumentu) uz punu suglasnost okupljenih velikaša (communi regni consilio) ugarsko-hrvatski kralj Bela II. podijelio "bosanski dukat" svome sinu Ladislavu. ${ }^{61}$ Iako je dokument/bilješka bila povjesničarima vrlo dobro poznata, te su se povodom onoga što u njoj piše vodile velike rasprave, ${ }^{62}$ rijetko je tko primijetio već i onaj najosnovniji problem koji proizlazi iz njezina sadržaja, a taj je pitanje datuma njezina nastanka.
Naime, tekst se uvijek reproducirao $s$ datumom naznačenim samo godinom 1137., pri čemu su tek rijetki primijetili kako se u pripovijedanju jasno naznačuje da je placitum kao pravni postupak doista otvoren na zasjedanju u Ostrogonu (a na tome je zasjedanju i stvarni fokus teksta) kasnije ipak nastavljen kada se na prijestolu našao nasljednik Bele II., njegov sin Gejza. ${ }^{63}$ Koliko sam mogao razabrati jedini koji su taj problem uočili bili su Imre Szentpétery i Nada Klaić. Szentpétery je stoga dokument okvirno datirao godinama 1141. do 1146., ${ }^{64}$ zacijelo računajući s time da se od 1146. Beloš (ovdje označen kao dux) pojavljuje u

MCCCVIII exarata, Cracoviae, 1916., str. 31: Secunda pars huius regni uocatur seruia... Continet [enim] in se tres prouincias, videlicet bosnam, maciam et marciam. Est enim hac pars regni sita circa ungariam. Postoji i novije izdanje Anonimova opisa, Tıвor Žıvković et al. (prir.), Anonymi Descriptio Europae orientalis, Istorijski institut, Beograd, 2013. no ono ipak, po preglednosti, ali i zbog brojnih neodrživih (pret)postavki priređivača, znatno zaostaje za onim O. Górke (odnosni tekst se u ovome izdanju nalazi na str. 122, dok komentar, ne baš najsretniji, vidi na str. 163-164, bilj. CXXX). Svakako je vrijedno primijetiti, zajedno s T. Zivkovićem i njegovim suradnicima, da Anonimov opis navodi samo one "provincije" koje je Dragutin dobio od ugarsko-hrvatskoga kralja, odnosno velikaša koji su u to doba stvarno (dok je kralj provodio vrijeme s Kumanima) upravljali Kraljevstvom, iako je izgleda imao pod svojom vlašću i dio Raškoga Kraljevstva. Anonim je po svemu sudeći dobar dio svojih informacija prikupio "očevidom" i iz osobnih kontakata, putujući barem dijelom po krajevima koje je kasnije opisao (Živkovićeva suprotna pretpostavka nema nijednoga elemenata uvjerljivosti), pa o tome svakako valja voditi računa.

61 Cijela isprava tiskana je u: Georgius Fejer, Codex diplomaticus Hungariae ecclesiasticus ac civilis, II., Budae, 1829., str. 88-92. Fotografija bilješke, koja se inače čuva u Beču, dostupna je kao: MOL DF 286312.

62 Pregled starije literature, one nastale prije Drugoga svjetskog rata, i mišljenja iznesenih u često žustrim raspravama vidi u: FERDo Šišić, Povijest Hrvata za kraljeva iz doma Arpadovića (1102-1301). Prvi dio (1102-1205) od Kolomana do Ladislava, HAZU, Zagreb, 1944., str. 54-60. Noviju literaturu nastalu na hrvatskom i srpskom jezičnom području prikazuje TiвоR Žıvкоvić, "Rama u titulaturi ugarskih kraljeva", u: Zbornik radova Vizantološkog instituta, XLI., Beograd, 2004., str. 153-158.

63 G. Fejer, Codex diplomaticus..., II., str. 88: His nihil contradicentibus, Bela Rex concessit Martino Comiti ad placitum sua ordinare. Gratiam, quam pater concesserat, concessit succedens filius in regnum Geuczha, praesente Belos duce.

64 Imre Szentpétery, Regesta regum stirpis Arpadianae critico diplomatica, I., MTA, Budapest, 1923., str. 26, br. 74. Vrijedi ovdje tek nuzgredno primijetiti kako F. Šišić (bez davanja bilo kakva argumenta) uz citat izvoda dokumenta što ga je po Fejerovu izdanju tiskao Smičiklas (DZ, II., str. 46) ispravlja datum: "izpravu valja datirati 1139. a ne (kao Smičiklas) 1137." (F. ŠIšıć, Povijest Hrvata za kraljeva..., str. 55, bilj. 22). 
vrelima s titulom palatina i bana. No, Szentpétery nije uzeo u obzir činjenicu da je Beloš nosio titulu bana barem od 1144 . godine, ako ne i ranije, kako se razabire iz datuma jedne isprave izdane u Splitu upravo te godine. ${ }^{65} \mathrm{~N}$. Klaić je pak ostala neodlučna glede vremena nastanka bilješke naznačujući samo to da je ona posve izvjesno nastala nakon smrti Bele II., "dakle nakon 1141. godine". ${ }^{66}$ Čini se ipak da pitanje Beloševe titule i nema tako presudno značenje za datiranje "vijećanja" na kojemu je Ladislav dobio "bosanski dukat" kako bi se moglo pomisliti. Teško je, naime, povjerovati da bi se placitum započet na zasjedanju u Ostrogonu pred kraljem Belom II. nastavio nekoliko godina kasnije, kada njega više nije bilo, dozvolom njegova nasljednika. Stoga, ako će se vjerovati onome što piše u ovome dokumentu, nastalom vjerojatno prije 1144 . godine, a nema razloga tako ne postupiti, valja pretpostaviti da je "vijećanje" u Ostrogonu obavljeno ne mnogo prije smrti kralja Bele II. koji je inače umro 13. veljače $1141 .{ }^{67}$ Činjenica da se u kasnijem dokumentu zbivanja datiraju upravo činom proglašenja Ladislava za duxa daje naslutiti kako je riječ o događaju važnom za one koji su nazočili i nečemu što je obilježilo samo "vijećanje" kao najvažniji pojedinačni "događaj". S druge strane, s obzirom na to da je novi $d u x$ u tome trenutku mogao imati šest ili sedam godina, ne bi trebalo imati iluzija glede toga je li on stvarno preuzeo upravu. Svakako to nije mogao učiniti, pa značenje toga događaja valja tražiti na drugoj strani. Sam bi čin, u svjetlu onoga što se i inače zna, valjalo promatrati u prvome redu kao neku vrst rituala opisanoga ukratko izričajem communi regni consilio ... dedit. "Vijećanje" i odnos ugarskih velikaša s vladarom ovoga doba opisao je u jednom, barem na prvi pogled, kontradiktornom izvješću Otto, biskup Freisinga, koji veli:
"Umijeće Grka imitiraju (Ugri) utoliko što nijednoj velikoj stvari ne pristupa- ju bez opetovanog i dugog vijećanja ... sakupljaju se na dvor svoga kralja svaki od najuglednijih noseći sa sobom svo- ju sjedalicu te ne zanemaruju baviti se i raspravljati o stvarima svoje države ... No svi se svome poglavaru tako poko- ravaju da svaki smatra opačinom da ne kažem ogorčiti ga otvorenim protivlje- njem, već povrijediti i potajnim šapta- njem ... Ako koji iz reda župana kralja ma i najmanje uvrijedi ili pak zbog toga, makar i nepravedno, bude optu- žen, bilo koji od najnižih službenika dvora poslan sam će ga, iako okružena pratiteljima, uhvatiti i staviti u okove te podvrći različitim mukama. Nijed- na poglavarova presuda se, kako je u nas običaj, ne moli od jednakih, optu- ženome se ne daje sloboda obrane, već se od svih volja poglavara prihvaća kao zakon. Ako pak kralj poželi povesti vojsku svi se bez protivljenja kao jedno tijelo sakupe." 68

65 DZ, II., str. 54-55, br. 54, 1144.: Temporibus ... Bellosi bani.

66 Nada Klaić, Srednjovjekovna Bosna. Politički položaj bosanskih vladara do Turtkove krunidbe (1377. g.), Eminex, Zagreb, 1994., str. 45.

67 F. ŠIšıć, Povijest Hrvata za kraljeva..., str. 60.

68 Bernhard von Simson (prir.), Ottonis et Rahewini Gesta Friderici I. imperatoris (Scriptores rerum Germanicarum in usum scholarum ex Monumentis Germaniae Historicis recusi), Hannoverae et Lipsiae, 1912., str. 50-51: In hoc tamen Grecorum imitantur sollertiam, quod nullam rem magnam sine crebra et longa consultatione adgretiuntur ... ad curiam 
Prividna proturječnost između predodžbe o živoj raspravi vladara i istaknutih pojedinaca (primores) o zajedničkim poslovima države (rei publicae statu) i na drugoj strani slike bespogovorne poslušnosti vladaru, rezultat je činjenice da Otto kao stranac jednostavno nije raspolagao "društvenim znanjem" potrebnim za dekodiranje obrazaca ponašanja. Elementi njegova pripovijedanja, poput donošenja vlastitih sjedalica, sam čin "vijećanja" kao i prividna poslušnost, svakako su ritualno ponašanje, ${ }^{69}$ jer je u stvarnosti politički život Kraljevstva u 12 . stoljeću obilovao uspjelim i neuspjelim urotama, nasilnim smjenama na prijestolu, uz bezbrojne primjere su- protstavljanja kralju, otvorenih pobuna i surovoga nasilja (nakon uspona Bele II. na prijestol samo je u jednome obračunu ubijeno 68 barones, kako su žrtve označene u mnogo kasnijem tekstu $\left.{ }^{70}\right)$. Nije teško naslutiti kako je ritual "vijećanja" u takvim okolnostima trebao stopiti kralja i njegove velikaše u jednu društvenu zajednicu učvršćujući, upravo u slučaju davanja "bosanskoga dukata", položaj postojećega dinastičkoga "kućanstva"/oikos koje je na taj način povećavalo svoj simbolički kapital u odnosu na druge moguće pretendente na prijestol, koji su također pripadali vladajućoj dinastiji. ${ }^{71} \mathrm{~K}$ tomu, valja svakako voditi računa i da je uređenje zasebnoga

regis sui, singulis ex primoribus sellam secum portantibus, conveniunt ac de suae rei publicae statu pertractare et discutere non negligunt... At omnes sic principi suo obsecuntur, ut unusquisque, ne dicam manifestis illum contradictionibus exasperare, sed et occultis susurriis lacerare nefas arbitretur... Quod si aliquis ex comitum ordine regem vel in modico offenderit vel etiam de hoc quandoque non iuste infamatus fuerit, quilibet infimae condicionis lixa a curia missus eum, licet satellitibus suis stipatum, solus comprehendit, in vinculis ponit, ad diversa toremntorum genera trahit. Nulla sententia a principe, sicut aput nos moris est, per pares suos exposcitur, nulla accusato excusandi licentia datur, sed sola principis voluntas aput omnes pro ratione habetur. Si quando vero exercitum rex ducere voluerit, cuncti sine contradictione quasi in unum corpus adunantur.

69 Literatura o ritualima je gotovo nepregledna, a ovdje se pojam rabi u širokom značenju koje mu daje Gerd Althoff, koji uz uzoran pregled literature raščlanjuje različite oblike rituala u društvima razvijenoga srednjeg vijeka: "O ritualima govorimo kada sudionici (društvenih transakcija) određene čine, ili radije nizove činova, složene naravi ponavljaju pod određenim okolnostima na isti ili vrlo sličan način i ako se ovo događa smišljeno, sa svjesnom namjerom ponavljanja poznatog. Idealni tip rituala postoji u umovima kako sudionika tako i promatrača te on dobiva materijalnu formu koja je lako raspoznatljiva u svojim različitim manifestacijama. Sudionici i promatrači postupaju svjesni toga da su ograničeni određenom shemom, što međutim ne znači da ritual neće imati željeni učinak" (Gerd Althoff, "The Variability of Rituals in the Middle Ages", u: Isti et al. (ur.), Medieval Concepts of the Past: Ritual, Memory, Historiography, Cambridge University Press, Cambridge, 2002., str. 71-72).

70 Opis "masakra" tradiran je u djelu nastalome dva stoljeća kasnije (Alexander DomanvszKy (prir.), "Chronici Hungarici compositio saeculi XIV.", u: Emericus SzentPÉTERY (ur.), Scriptores rerum Hungaricarum tempore ducum regumque stirpis Arpadianae gestarum, I., Budapestini, 1937., str. 446-447) te ga se stoga ne čini uputnim podrobnije raščlanjivati.

71 Vladavina Bele II. i njegova sina i nasljednika Gejze II. bila je doista obilježena upornim pokušajima konkurentskoga pretendenta, Borisa, sina kralja Kolomana iz drugoga braka, da se uz vanjsku pomoć dočepa krune, o čemu mnogo informacija u već citiranome djelu donosi upravo biskup Otto. Za društvenu atmosferu stvorenu Borisovim nasto- 
"dvora" za novoga duxa pripadnicima (još uvijek rodovske) elite otvaralo perspektivu za novi niz časti. ${ }^{72}$ No, $s$ time u svezi odmah se postavlja pitanje kako je i kroz koje mehanizme bila alimentirana pozicija duxa i nje- govih "dvorjanika", odnosno je li sam čin uspostave "bosanskoga dukata" značio da je tamo uspostavljena više ili manje učinkovita uprava makar i $s$ rudimentarnom administracijom, slijedom čega bi iz zemlje dolazio i

janjima, za koja je potporu tražio kako u Bizantu tako i u Svetom Rimskom Carstvu, vidi: Ferenc Makx, The Arpáds and the Komneni. Political Relations between Hungary and Byzantium in the 12th Century, Akadémiai Kiadó, Budapest, 1989., str. 31 i d. Kao i najveći dio moderne mađarske historiografske produkcije, međutim, i ovo je djelo u prvome redu fokusirano na formalnu stranu procesa stvaranja i izgradnje institucija "povijesne Mađarske", fikcionalne "nacionalne" političke tvorbe što ju je izgradila lokalna historiografija u političkoj atmosferi "dualizma" Austro-Ugarske u drugoj polovici 19. stoljeća kao "povijesnu podlogu" stvarnih političkih odnosa toga doba. Ta historiografska fikcija, izrasla iz "'historijske zablude' izjednačavanja podanika krune sv. Stjepana s etničkim-kulturnim Mađarima" (J. M. BAK, "A Kingdom of Many...", str. 47), a u kojoj se srednjovjekovni vladari ponašaju kao pravi vođe "nacionalnih pokreta" 19. stoljeća te vode "vanjsku politiku" kao da su na čelu suvremene "suverene nacionalne države" okružene istim takvim političkim entitetima, i danas velikim dijelom zaklanja mađarskim povjesničarima pogled na stvarnost davno nestaloga svijeta u mjeri u kojoj njihova doista ozbiljna i obuhvatna istraživanja često ne daju odgovarajući konačan rezultat.

72 Organizaciju posebnoga "dvora" za hercega Ladislava posvjedočuje pojava stanovitoga comesa Petra, za kojega se u dva dokumenta iz 1146. godine veli da je magister Ladislai ducis (G. Wenzel, Codex diplomaticus..., I., Pest, 1860., str. 57, br. 24; str. 58, br. 25), što bi se moglo smatrati znakom da je zasebni "dvor" doista bio, barem u zametku, uspostavljen (značenje titule magistra i položaj onoga tko ju je nosio u dvorskoj hijerarhiji daleko su od jasnoga, ali se on svakako rabi barem kroz 12. stoljeće. Usp. DZ, II., str. 211, br. 201, 30. 9. 1187.; str. 310, br. 290, 1198.). Na ta je dva dokumenta svojedobno upozorila N. Klaić (N. KLAIć, Srednjovjekovna Bosna..., str. 46), no onda je nastavila dokazivati kako titula $d u x$, koja se tu rabi za Ladislava, nije ona "bosanskoga dukata" i to na način koji gotovo da izaziva nevjericu. Svoju pretpostavku izrečenu u jednoj rečenici, već je u sljedećoj pretvorila u nedvojbenu činjenicu. (Isto, str. 47: "Nije li dakle moguće da je Ladislav, u trenutku kada je njegov brat Geza proglašen vitezom - a to je upravo 1146. g.! - dobio naslov vojvode (dux), čast koju je, kao najodličniju nakon kraljevske, nosio do toga vremena Beloš? S obzirom na to da je sadašnja Ladislavova vojvodska titula mnogo vrednija od one koju je po očevoj želji dobio 1139. g., neće biti nikakve sumnje da Ladislav nije više dux bosnensis, nego $d u x=$ prestolonasljednik, što drugim riječima znači da mu je brat Geza htio ili morao prepustiti čast koju je nakon očeve smrti nosio njihov ujak Beloš" - sve naglašeno u izvorniku). Na osebujni stil rada i pisanja N. Klaić (u kojem se dokumenti proglašavaju krivotvorinama, samo kako bi se iz njih mogli odstraniti oni elementi koji autorici ne dogovaraju a uzimati oni koji autorici odgovaraju, pretpostavke u trenu postaju činjenice i sl.), njezinu slabu opremljenost za istraživanje srednjega vijeka (manjkavo znanje latinskoga i zastrašujuće nepoznavanje literature nastale izvan hrvatskoga i srpskoga jezičnog područja), nepoznavanje golemoga fonda neobjavljenih vrela za hrvatsku povijest toga doba te ezoteričnu ideološku koncepciju izgrađenu na postavkama Milovana Đilasa i Miroslava Krleže, dosad sam se osvrnuo u nekoliko navrata (a pripremam i posebnu raspravu o "avnojskoj koncepciji srednjega vijeka"). Ništa od toga ovdje ne bih ponavljao, no valja ipak upozoriti na činjenicu da se opus N. Klaić još uvijek, kao neka zlokobna sjenka, nadvija nad hrvatskom medievistikom, a glorifikatorski duh, koji se očituje citiranjem autoričinih načelnih stajališta bez upuštanja u raščlambu odnosa tih načelnih stajališta sa samim njezinim postupkom "povjesničarenja" i njegovim rezultatima, obilježava gotovo cijeli zbornik posvećen njezinu djelu - usp. Tomislav Galović - Damir Agičić (ur.), Nada Klaić i njezin znanstveni 
neki stvarni prihod. ${ }^{73}$ Ako odgovor potražimo u spomenutome izvješću s kraja 12. stoljeća, o kojem je bilo riječi u bilješci, ${ }^{74}$ on bi morao biti niječan. To izvješće navodi Ramu kao zasebnu "zemlju" (terra), no u svezi s tom "zemljom" ne spominje se nikakva crkvena organizacija (za "zemlju" Ugarsku, koja je označena kao "glava" - caput, dat je popis svih biskupija $s$ iznosima njihovih prihoda, dok je za "zemlju" Dalmaciju, očito u onome antičkome značenju toga pojma, navedeno tek toliko da ima dvije nadbiskupije, Zadarsku i Splitsku, koje zajedno imaju deset biskupa sufragana; prihodi tih dviju nadbiskupija izrazito su niski te je primjerice po ovome izračunu zagrebački biskup, kao jedan od biskupa s osrednjim prihodima, godišnje ipak ubirao čak tri puta veći iznos od zadarskoga nadbiskupa). Od hrvatskoga je hercega, pak, kralj dobivao (navodno) 10.000 maraka (srebra), što bi, sudi li se logikom da je od županskih prihoda kralj dobivao trećinu, moglo značiti da je hercegov ukupni prihod ovdje prikazan kao 30.000 maraka. No, P. Engel je s pravom iskazao popriličnu skepsu glede točnosti svih ovih podataka, a za predmet o kojem se ovdje raspravlja svakako je najvažnije da se "zemlja" Rama uopće ne pojavljuje kao izvor bilo kakvih prihoda. Bez obzira dakle koliki i kakvi kraljevski prihodi bili, i držeći se Engelova suda da izvješće ipak otkriva strukturu i proporcije tih prihoda, valja zaključiti da na njih realno nije ni na koji način utjecalo ono što je eventualno dolazilo iz "zemlje" Rame.

No, je li Rama u ovome izvješću, ali i u kraljevskoj tituli ugarsko-hrvatskih vladara doista identična $s$ Bosnom? U historiografiji je, barem glede toga, vladalo jednoglasno prihvaćanje takva gledišta, sve dok ga u pitanje nije doveo srpski povjesničar Tibor Živković. Prije desetak godina on je objavio raspravu u kojoj je energično i samouvjereno ustvrdio

i nastavni doprinos razvoju historiografije, FF Press, Zagreb, 2014. (u tome je smislu više no indikativno da nijedan od autora priloga u tome zborniku nije primijetio pojam "historijska uloga" koji se u opusu N. Klaić relativno često pojavljuje, čak i u naslovima pojedinih rasprava ili poglavlja u knjigama, a koji je ključan za dekodiranje njezine cjelovite ideološke koncepcije povijesti). Posve očekivano, u tome zborniku o knjizi Srednjovjekovna Bosna govori tko drugi do D. Lovrenović i to na takav način da je posve nejasno što je napisala autorica a što je rezultat "suvremenih analiza", pri čemu je to tek drugi naziv za njegove vlastite tekstove (D. Lovrenović, "Formiranje srednjovjekovne bosanske države i ugarsko-bosanski odnosi u knjizi Srednjovjekovna Bosna Nade Klaić", u: Nada Klaić..., str. 332 - vjerojatno je ovdje D. Lovrenović nadahnut postupkom same N. Klaić koja je za svoja vlastita djela često koristila naziv "kritička historiografija"). U usporedbi s ovim smušenim i nerazgovjetnim tekstom (u koji je strpano "sve i svašta", od Ericha Fromma do "bill-boarda Hrvatske stranke prava $\mathrm{BiH}^{\prime \prime}$ čak se i autorova knjiga kojoj sam posvetio početni dio ove rasprave doima kao ozbiljno znanstveno djelo.

73 Zasebna upravna područja Hrvatskoga Kraljevstva (Dalmatia et Croatia ili tocius Sclavonia, u dokumentima do sredine 70 -ih godina 13. stoljeća) i Transilvanije su, prema jednome (i jedinom takvom) izvješću s kraja 12. stoljeća davala $6 \%$, odnosno $9 \%$ ukupnih kraljevskih prihoda (o vremenu i načinu nastanka toga izvješća te njegovu sadržaju vidi: P. ENGEL, The Realm..., str. 61-63).

74 Tekst je uz mnoga izdanja dostupan u DZ, II., str. 133-134, br. 129, no s posve pogrješnim datiranjem, "1173-1176." 
da Rama, kao "zemlja" u tituli ugarsko-hrvatskih kraljeva, i Bosna nisu ista stvar. Njegov temeljni argument polazi od sljedeće tvrdnje: "Uvidom u objavljene povelje ugarskih vladara uočava se da se Rama izjednačava sa Bosnom isključivo od XV veka." ${ }^{75} \mathrm{Za}$ svoje stajalište Živković nalazi potvrdu i u obliku titule bosanskoga bana zabilježene sredinom 14. stoljeća te iz toga, nekoliko rečenica dalje, jasno zaključuje: "Rama je, dakle, samo jedna od 'zemalja' koja ulazi u titulaturu bosanskog bana." U zaključku, međutim, svoje rasprave i pokušaju da odgonetne otkud Rama u tituli ugarsko-hrvatskih kraljeva napušta Živković sigurno tlo sačuvanih vrela i upušta se u kombinacije koje nemaju nikakvo uporište u sačuvanim pisanim tragovima. Posljednja njegova nesporna tvrdnja jest ona da je budući kralj Bela II. bio oženjen s kćeri srpskoga velikog župana Uroša I. Od te neprijeporne činjenice počinju se redati sve fantastičnije kombinacije bez ikakva pokrića. Prvo dolazi pretpostavka da je Jelena, a tako se zvala Belina žena, "kao srpska princeza mogla mladoženji da donese miraz iz Srbije, koji je u srednjem veku činila zemlja, odnosno neka od oblasti zemlje iz koje je dolazila nevesta". ${ }^{76}$ Smatrajući kako je ranije dokazao, pozivajući se na Ljetopis popa Dukljanina i interpretaciju toga teksta iz pera Vladimira Ćorovića, da je Rama pripadala Raškom Podgorju, ${ }^{77}$ svoje raspravljanje završava Zivković ovako: "Stoga se nameće zaključak da je Rama u titulaturu ugarskih vladara mogla ući onog trenutka kada je Bela II Slepi postao ugarski kralj, a to je bilo 1131. godine."78

Živkovićevu sam raspravu nešto iscrpnije prikazao jer me je njegova argumentacija doista uvjerila u neke od postavki, i to upravo one koje proturječe svim dosadašnjim mišljenjima, uključujući i ono moje. Naime, svojedobno sam upozoravajući na tekst Otta, biskupa Freisinga, u kojem on pozicionira Ramu kao "zemlju" u susjedstvu Ugarske, upravo to smatrao dokazom vrlo ranoga izjednačavanja Rame i Bosne. ${ }^{79}$ Ćinilo mi se tada, kao uostalom i gotovo svim povjesničarima koji su radili na tim problemima, da se vremenski podudarna pojava "zemlje" Rame u tituli ugarsko-hrvatskih vladara (1138. godine) i "bosanskoga dukata" (1137. ili 1139. godine, ovisno o datiranju ranije raščlanjene bilješke) skladno dopunjuju, tim prije što je dovoljan jedan pogled na zemljovid da bi se zaključilo kako je lako "pomiješati" Ramu i Bosnu.

75 T. Žıvкоvić, "Rama u titulaturi...", str. 160.

76 Isto, str. 163.

77 Isto, str. 161. O ozbiljnosti i utemeljenosti tih i takvih interpretacija Ljetopisa ponajbolje govori činjenica da je V. Ćorović za svoja stajališta o fantazmagoričnom "Raškom Podgorju" (koje je dio povijesne stvarnosti isto onoliko koliko i "krunidba kralja Tomislava na Duvanjskom polju") potporu našao "u dva zanimljiva toponima severoistočno od Konjica, u području Radobolje prema Bosanskoj planini - Raška strana i Raški Dol". Po toj istoj logici mogao je zaključiti i da je Istra bila dio "Raškog Podgorja" jer se tamo nalazi rijeka Raša!

78 Isto, str. 163.

79 M. Ančıć, "Bosanska banovina...", str. 14. 
No, je li doista sve tako jednostavno? Čini se ipak kako je T. Živković bio u pravu. Ova dva zemljopisna i političko-administrativna pojma poistovjećuju se tek početkom 15 . stoljeća. Sačuvani (i poznati) dokumenti u kojima se oni spominju prije toga izrazito su rijetki i teško je među njima pronaći one u kojima se oba ta pojma pojavljuju zajedno, no na svu sreću ima i takvih. U jednome privilegiju što ga je izdala kancelarija kralja Bele IV. 31. listopada 1244. prepričan je jedan još stariji privilegij izdan u ime istoga kralja (ali bez navođenja njegova datuma) kojim je on svome bratu, tadašnjem hrvatskom hercegu Kolomanu, potvrdio neke posjede "u ono vrijeme kada je uzevši na se znak križa u Kristovo ime krenuo protiv patarena u Bosni i u zemlji Rami".80 Nadovezujući se na to valja upozoriti i na činjenicu da već spominjani pogled na zemljovid i poziv na njega, koji je kod modernih povjesničara vrlo često i nesvjestan, jest zapravo jedna vrst optičke iluzije. Dovoljno je samo jednom proći danas relativno lako savladivim cestama od Tomislavgrada preko Rame do Jablanice, ili pak od Jablanice do Travnika, da bi se razumjelo kako su ovi izrazito planinski i teško prohodni krajevi u srednjem vijeku doista vrlo lako mogli biti doživljeni pa potom u imaginaciji i predstavljeni kao zasebna "zemlja". Valja pri tomu svakako držati na umu da je doživljaj prostora u srednjovjekovnom svijetu bio bitno drugačiji od onoga današnjeg, određenoga u prvome redu duboko ukorijenjenom zemljovidnom predodžbom fizičkoga prostora, predodžbom s kojom smo u stalnom i bliskom dodiru još od najranijega djetinjstva. Nasuprot tomu sve do duboko u 15. stoljeću
"zemljovidi su bili poglavito itinerari koji su reprezentirali mreže međusob- ne povezanosti naselja i drugih mjesta $s$ izrazitom društvenom, gospodar- skom ili vojnom važnošću. Moguće je da su i oni 'mentalni zemljovidi', o kojima govore geografi, bili konstru- irani na sličan način te su onodobni ljudi vjerojatno imali teškoća u konci- piranju međusobnoga odnosa velikih blokova dvodimenzionalnoga prostora ... Kroz najveći dio (predmoderne) po- vijesti objekt kontrole, ako ne već de iure a ono de facto, je bio demografski prostor: ono što je bilo važno bili su pučanstvo, resursi i prometne mreže te onaj fizički prostor koji su ti elemen- ti zapremali, a ne fizički prostor kao takav". ${ }^{81}$

Uzimajući sve ovo u obzir nije teško razumjeti zašto je "zemlja" Rama doživljavana kao zasebno područje u odnosu na ("zemlju") Bosnu, kao takva onda ušla u vladarsku titulu te kako je spajanjem ta dva zemljopi-

80 G. Wenzel, Codex diplomaticus..., VII., str. 166-167, br. 109. Tekst cijeloga prepričanog i nedatiranog ranijeg privilegija glasi: ... cum quasdam possessiones, que ob magnam et notoraim infidelitatem suorum possessorum ad manus Regias fuissent deuolute, nos eas karissimo fratri nostro Colomano Regi et Duci tocius Sclauonie pijsime recordacionis contulissemus, quasdam uero idem Rex, quas empcionis titulo possederat, uel alias quoquo modo iusto ad eundem deuenerant, sibi pleno et perpetuo iure cum omnibus ipsarum pertinencijs conferendo in perpetuum possidendas, ad peticione ipsius eo tempore, cum assumpto signo crucis contra Paterinos in Boznam et in terram Rame pro nomine Christi proficiscetur, confrimassemus (naglasio M.A.).

81 John Landers, The Field and the Forge. Population, Production, and Power in the Preindustrial West, Oxford University Press, Oxford, 2003., str. 254, 264. 
sno-upravna pojma stvorena podloga za koncipiranje "bosanskoga dukata". No, takvo postavljanje stvari odmah otvara i dva nova pitanja. Prvo: što je to "zemlja" 12. stoljeća, i drugo: što se promijenilo do početka 15 . stoljeća pa se tada moglo početi izjednačavati te pojmove, ili drugim riječima kako se od izričaja Bozna et terra Rame došlo do izričaja Ramae seu Boznae. $\mathrm{Na}$ drugo od ovih pitanja vratit ću se malo kasnije, tek nakon što pretresem problem "zemlje" i s njime usko povezano pitanje stvarne vlasti u "bosanskome dukatu".

Prije petnaestak godina, ${ }^{82}$ potaknut idejama njemačkoga povjesničara Otta Brunnera, upozoravao sam na značenje što ga u srednjovjekovnome svijetu ima pojam zemlja/terralland tada još nesvjestan da mentalna slika koja stoji iza toga izričaja privlači pozornost i srpske historiografije. Naime, tijekom druge polovice 90 -ih godina 20. stoljeća beogradski povjesničari Miloš Blagojević i Siniša Mišić objavili su nekoliko tekstova koji će se pokazati vrlo utjecajnima u srpskoj medievistici sve do danas, ${ }^{83}$ a što se jasno razabire već i na razini kategorijalnoga aparata kojim se koristio $\mathrm{T}$. Živković u svojim ovdje prikazanim raščlambama vezanim uz Ramu. No, naša se shvaćanja poprilično razlikuju. Dok sam ja smatrao, a i danas smatram, ideje O. Brunnera veoma poticajnim za razglabanje konceptualizacije i organizacije vlasti i društvenoga uređenja u fizičkome prostoru na vrlo širokom prostoru između Jadrana i Baltika, dotle su srpski povjesničari smatrali, kao što i danas drže, da je "zemlja" specifičnost i posebno obilježje srpskoga razvoja. Odatle je proizašao i izričaj "srpske zemlje" koji se obilato koristi u novijoj produkciji čiji je jedini cilj pokazati i dokazati "izvorno srpstvo" cijeloga onog područja koje na zapad seže sve do Une, a koji se zamišlja kao teritorij koji su Srbi "izvorno naselili" te im stoga po tome "pravu" i danas "pripada". ${ }^{84}$

82 M. Ančić, Na rubu Zapada..., str. 30 i d.; 147 i d.

83 Riječ je o raspravama sabranim u: Miloš Blagojević, Državna uprava u srpskim srednjovekovnim zemljama (ćir.), Službeni list SRJ, Beograd, 1997. te posebice o raspravi: SinIša Mišıć, "Zemlja u državi Nemanjića", u: Godišnjak za društvenu istoriju, 2-3, Beograd, 1997.

$84 \mathrm{Na}$ tim misaonim temeljima postavljena je cijela produkcija o "srednjovekovnim zapadnim srpskim zemljama" što je u posljednjih dvadesetak godina ugledala svjetlo dana u Beogradu, kako je reprezentiraju objavljene "monografije o istorijskoj geografiji" (riječ je o doktoratima ili magisterijima branjenim na Filozofskome fakultetu u Beogradu): S. Mıšrć, Humska zemlja u srednjem veku (ćir.), Filozofski fakultet u Beogradu, Beograd, 1996.; J. Mrgić-Radojčić, Donji Kraji...; Tanja Ribar, Zapadne strane u srednjovekovnoj bosanskoj državi (ćir.), Svet knjige, Beograd, 2009. Iz naizgled sličnih shvaćanja polaze i radovi također beogradskoga povjesničara Nevena Isailovića (najveći dio je dostupan na internetskoj adresi:https://iib-ac.academia.edu/NevenIsailovic (20. 5. 2015.), koji ipak imaju nešto drugačiju narav. Moglo bi se bez zazora ustvrditi kako je N. Isailović zapravo prvi "srpski stručnjak za hrvatsku srednjovekovnu istoriju" (što bi zapravo trebala biti legitimna i normalna pozicija - na hrvatskoj strani još ni izdaleka nema ničega sličnog). Cijelu ranije navedenu produkciju sumira u novije vrijeme S. Mıšrć, Istorijska geografija srpskih zemalja (ćir.), Magelan pres, Beograd, 2014. (o kakvoj vrsti literature je tu riječ posve je jasno već s pogledom na korice knjige, gdje u jednome medaljonu, valjda kao preporuka ćitatelju, stoji: "slavna srpska istorija"). 
Kako sam o nekima od djela iz te produkcije već govorio a ne smatram korisnim vraćati se na promašaje jedne autistične produkcije koja, kao i ona Lovrenovića, ničemu ne služi dok tek rijetkima može donijeti korist (u ovome konkretnom slučaju oni koje bi trebalo uvjeriti da su "Srbi" to ne čitaju, jer već znaju da to nisu; oni koji eventualno čitaju djela preporučena kao "slavna srpska istorija", a tih je vrlo malo, ionako već znaju da su Srbi, pa im to samo osigurava ugodu ostanka u poznatom), okrenut ću se onomu što doista ima, barem po mome sudu, stvarno značenje u pokušaju objašnjenja načina na koji je nastao i kroz dugo vrijeme konstruiran svijet u kojem živimo. Dakle, "zemlja" (terra, land itd.) kao koncept i mentalna slika prihvaćena i ukorijenjena na veoma širokom prostoru nije ni "germanska" ni "slavenska" institucija, ili se barem ne može definirati u tim parametrima, iako je valja raščlanjivati ako je ikako moguće uz pomoć pisanih tragova na vernakularnim (govornim) jezicima pučanstva koje ju tvori. Ovo upozorenje $\mathrm{O}$. Brunnera temelji se na činjenici da su "zakon" (kao jednu od temeljnih značajki "zemlje" i kad nije postojao u pisanoj formi) oblikovali ljudi koji su govorili njemački (hrvatski, srpski, poljski itd.) jezik, u kojem su bila artikulirana načela i norme njihova stvarnoga ponašanja i djelovanja, ${ }^{85} \mathrm{pa}$ je tek naknadno taj "zakon" eventualno preveden u učeni jezik srednjega vijeka, latinski. Ta je mentalna slika podrazumijevala političku zajednicu koja posjeduje svoj (običajni, a tek mnogo kasnije i ne u svim slučajevima pisani) zakon koji se odnosi na određenu populaciju u demografskome prostoru (o kojem je gore bilo riječi). Zajednica svoje nutarnje odnose uređuje i održava sukladno svome zakonu te se na taj način konstituira u odnosu na vanjski, "drugi" svijet.

Nutarnja je struktura "zemlje" još uvijek poprilična zagonetka, a rijedak uvid u tu strukturu omogućuju dva dokumenta iz sredine 13. stoljeća na koja se u historiografiji nije obraćala posebna pozornost. Riječ je o dokumentima kojima se registrira postupak sklapanja mira stanovnika područja koje se zove Krajina, modernoga Makarskog primorja, dijela srednjovjekovne Humske zemlje, s Dubrovčanima i Rabljanima. ${ }^{86}$ Okolnosti nastanka ugovora nisu ovdje (zasad) od posebnoga interesa, osim činjenice da su oba ugovora sastavili gradski bilježnici, pri čemu je razlika među njima ipak bitna. Ugovor o miru s Dubrovčanima napisan je govornim, hrvatskim jezikom, dok je onaj s Rabljanima napisao zadarski javni bilježnik latinskim jezikom. Razlike u načinu na koji se u tim ugovorima opisuje društvena stvarnost jasno potvrđuju vrijednost Brunnerove primjedbe o

85 O. Brunner, Land and Lordship. Structures of Governance in Medieval Austria (izv. Land und Herrschaft. Grundfragen der territorialen Verfassungsgeschichte Österreichs im Mittelalter, 1965.), University of Pennsylvania Press, Philadelphia, 1992., str. 155.

86 Dokumenti su tiskani u: LJ. STOJAnović, Stare srpske povelje..., I., str. 21-23, br. 24, 11. 2. 1247. (ugovor s Dubrovčanima) te DZ, Dodaci, I., str. 214-216, r. 167, 29. 6. 1256. (ugovor s Rabljanima). O Humskoj zemlji, pa i Krajini kao njezinu dijelu, vidi: M. ANČIĆ, Na rubu Zapada..., str. 141-176. 
važnosti vernakularnoga izričaja pri raščlambi društvenih struktura. Prema tekstu ugovora s Dubrovčanima u grad je došao "is' Kraina sel'" (dakle, iz krajinskih sela) stanoviti Odola Predenić, i to "o' moih' stareh', pris'nih' prijatelih' i od' vseh' ljodeh' Krainaneh'" sa zadatkom "postaviti vječni mir' i ljobev' megu Krainaneh i megu Dubrovčanih'". "Ljudi Krajinjani" su dakle posebna društvena zajednica koja kao vrh svoje vlastite organizacije ima tijelo u ugovoru nazvano "vijeće" (u posebnome tekstu kojim je propraćeno polaganje prisege o pridržavanju odredbi pojavljuje se i pojam "općina" no ne čini se da se on odnosi na "Krajinjane"), ${ }^{87} \mathrm{za}$ razliku od "zemaljskoga shoda" koji predstavlja "zajednicu ljudi Humske zemlje", a koji se tradicionalno (i ritualno) okupljao kod "Bijele crkve" u Brotnju. Na čelu te zajednice nalazi se "knez" a tvore je rodovske zajednice njegove "bratie" - Dedomirića, Ježobodaca i Tvrdinića - te onih koji se očigledno ne ubrajaju u "braću" u užem značenju - Bjelimir i Stojanić, Gradiša Hodimirić i njegovi sinovci, kao i Razmen Vukašić, pri čemu se iza tih imena očito krije neka vrst lokalnih uglednika (sličnu sliku ocrtava prisega Dubrovčana, koji se obvezuju "da ne pakostimo tebe Odolje Prede- niku ni tvoimi starimi ni pris'nim' ti ni Krajaninom'" - riječ je dakle o tri kategorije Odolinih društvenih veza: "stari"/rodbina, "prisni"/društveno bliski i svi ostali, "Krajanini"; no, valja i to primijetiti: svi se "Krajanini" kao sudionici "vijeća" ipak mogu podvesti i pod pojam "bratia", kao u onome tekstu na posebnom komadu pergamene, gdje se za Odolu veli "pride Odola brat' naš'"). Kad su, pak, potvrdivali odredbe što ih je Odola ugovorio u ime cijele te zajednice, upravo su ti spomenuti obećali uskratiti mjesto u "vijeću" i solidarnost svakome onomu tko se prisegom ne bi obvezao na prihvaćanje dogovora s Dubrovčanima ("a ki Krajanin' se u semu ne roti da ga ne primemo megu nas' u veku, ne da bude sven' nas' i pače v'sje jegovo da zatiramo" - takav se očigledno više ne može podvesti pod pojam "brat' naš'"). Slika koju ocrtava u pisani oblik pretočeni dogovor dviju zajednica prilično je, dakle, jasna - "ljudi Krajinjani" ugovaraju s "dubrovačkom općinom" određene odnose, pri čemu su iz cijeloga posla barem formalno isključeni na jednoj strani "humski zemaljski gospodar" a na drugoj mletački knez Dubrovnika kao izaslanik mletačkoga dužda. Ugovorene uvjete budućih odnosa i procedure za razrješavanje konflik-

87 Posebni tekst kojim je registrirano polaganje prisege o pridržavanju uredbi koje je Odola ugovorio bio je, kako veli izdavač, "Na komadiću pergamenta obešenu o pečat" (LJ. Stojanović, Stare srpske povelje..., str. 23). Naziv "općina", koji se tu pojavljuje nije lako interpretirati jer se nalazi u sklopu izričaja "i ot' vse opštine pride Odola brat' naš' i Gr'gur' ot' kneza dubrovačkoga". Tako se artikulirani izričaj definitivno odnosi na vrijeme kad se Odola Predenić poslije pregovora u Dubrovniku vratio u Krajinu te se može tumačiti i tako (osim, dakako, da je on bio izaslanik "općine" Krajinjana) da je dubrovačka općina sklopila ugovor s Odolom pa on sada dolazi s tim ugovorom od "općine (Dubrovačke)", dok je u toj situaciji stanoviti Grgur izaslanik dubrovačkoga kneza iz Mletaka, koji zapravo kontrolira cijeli postupak pregovaranja kao vanjski (nadređeni) čimbenik. Takvo tumačenje nalazi potvrdu u tekstu ugovora, gdje se veli kako je Odola ugovarao mir "i s' sud'cje i s' vet'nici i s' svov' opkina Dubrovačka" - dubrovački je knez očito namjerno izostavljen. 
tnih situacija prihvaćaju u Krajini u ime cijele zajednice ("braće" u širem značenju) "knez" i (po svemu sudeći) lokalni uglednici, no koji se (barem za ovu prigodu) ne odlikuju nikakvim posebnim titulama ili oznakama.

Ponešto je, pak, drugačija slika koju ocrtava ugovor s Rabljanima. Iz sadržaja se, naime, dokumenta razaznaje da je odredbe toga ugovora s "ljudima Krajine i Vrulje" 88 ugovorio rapski knez, pa je onda taj dogovor potvrđen na posebnome "vijećanju" između rapskih predstavnika i poimence navedenih čak četrnaestorice "Krajinjana i Vruljana" upriličenome u Zadru. Ovdje se niti jedan od četrnaestorice ne izdvaja a svi zajedno zastupaju svoje "srodnike i zajednicu" (per se et suos parentes omnes et comunitatis sue se... obligantes - teško je oteti se dojmu da je riječ o formuli koju koristi javni bilježnik, a ne o izravnom prijevodu onoga što su sami izrekli "Krajinjani i Vruljani"). No, i ovdje se dade razaznati postojanje sloja lokalnih ugled- nika koji su posjedovali ovlasti javnoga djelovanja, pa su slovom ugovora oni Krajinjani i Vruljani koji bi sudjelovali u nekom pothvatu tijekom kojega je nanesena šteta Rabljanima bili dužni po povratku u svoj kraj svoje "starije" (uglednije, maiores, ili "didiće" koji se spominju u poznatoj Povaljskoj listini) izvijestiti tko je sudjelovao u takvome pothvatu, da bi onda ti "stariji" (ugledniji) proveli istragu i oduzeli sva dobra koja su opljačkana Rabljanima. ${ }^{89}$ Iako riječ maiores iz ugovora s Rabljanima nije izravni ili doslovni prijevod izričaja "dedišti (vladanje otoč'skomu)", a kojim se zajednički opisuju "knez otoka", "župan", "sudac" i "brašćik" u Povaljskoj listini iz 1184. godine, ${ }^{90}$ nije teško raspoznati istu semantiku obaju pojmova. Upravo bi od osoba kakve su "knez", "župan" ili "sudac", jednom riječju "dedića vladanja" u smislu onih koji polažu nasljedno pravo na "vlast", trebalo očekivati provođenje istrage i oduzimanje onoga što se nije

88 "Vrulja" je do danas sačuvani toponim na obali između Makarske i Omiša kod Brela - oblici Berulia (taj se pojavljuje još u čuvenome djelu iz 10. stoljeća De admnistrando imperio što se uobičajeno pripisuje caru Konstantinu VII. Porfirogenetu), Vrulja, Brelo i Brela, očito se odnose na širi prostor i ljudsku zajednicu koja ga nastava, paralelnu barem još u 13. stoljeću onoj "Krajine". U samome pisanom dokumentu uporabljen je izričaj homines de la Crayna et della Vrulla koji ima jasnu paralelu u onome "v'si ljude Krainane" iz ugovora s Dubrovčanima i zapravo je izravni prijevod riječi kojima su sudionici pregovora sami sebe opisivali.

89 Krajinjani i Vruljani koji bi zbog spleta okolnosti sudjelovali u bilo kakvome nanošenju štete quam ciçius ad suas terras uel loca reuersi fuerint, debent inquirere et suis maioribus palam manifestare illos qui Arbensibus dampnum fecerint, et ipsi sui maiores debent inquirere et exigere bona Arbensium et recuperare bona fide ab illis qui acceperint toto posse - DZ, Dodaci, I., str. 215 (naglasio M.A.).

90 Usp. Franjo RačKi, "Najstarija hrvatska ćirilicom pisana listina", Starine JAZU, 13, Zagreb, 1881., str. 205-206. Otočni svijet, u organizaciju kojega uvid omogućuje Povaljska listina, u ovo se doba još nije bitno razlikovao od onoga na susjednome kopnu. Te će se razlike pojaviti prvo s utjecajem mletačke uprave od druge polovice 13. stoljeća nadalje, a onda još više produbiti s otomanskim osvajanjem kopnenih područja i istodobnim ostankom otoka pod mletačkom vlašću od 16. stoljeća. Stoga je Povaljska listina izvanredan usporedni materijal za ovakav tip raščlambi. 
smjelo pljačkati, a što su prema slovu ugovora s Rabljanima trebali provesti maiores. $S$ druge strane, kao i u slučaju ugovora s Dubrovčanima, nigdje se u ovome ugovoru ne može jasno razabrati bilo kakva uloga "zemaljskoga gospodara", što svakako valja dovesti u svezu s činjenicom da su inače oba ugovora usmjerena poglavito na sudjelovanje "Krajinjana" (i "Vruljana") u pothvatima s kojima njihov "zemaljski gospodar" i nije (barem formalno) imao ništa. Teško je, međutim, povjerovati da "zemaljski gospodar" na neki način nije sudjelovao u eventualnoj dobiti koja je za njegove podanike iz svega proizlazila pa susljedno tomu da ni u ovim ugovaranjima nije igrao nikakvu ulogu. Tu bi se možda onda moglo naslutiti objašnjenje asimetričnoga položaja "Krajinjana" (i "Vruljana") spram Dubrovčana i Rabljana. U oba ugovora oni su, naime, slabija strana te preuzimaju znatno veće obveze od druge ugovorne strane, pri čemu se dobiva dojam da su na neki način prisiljeni sklopiti ovakve sporazume. Objašnjenje bi se moglo tražiti u složenoj političkoj poziciji tadašnjega "humskoga gospodina", kneza Andrije, ${ }^{11}$ koji je svoje podanike jednostavno rečeno mogao prisiliti na sklapanje ovakvih ugovora za račun svojih odnosa s mletačkim duždom (i Rab i Dubrovnik su inače pod njegovom vrhovnom vlašću), a da pri tomu ipak ne ulazi u otvoreni sukob s omiškim Kačićima. Takvo tumačenje nalazi potvrdu u samome sadržaju obaju ugovora, jer se njima "Krajinjani" (i "Vruljani") zapravo obvezuju ne sudjelovati nadalje u pomorskim pothvatima Omišana, odnosno na sebe posve preuzimaju odgovornost za takvo postupanje, oslobađajući svoga "gospodara" obveze da im pruži zaštitu u slučaju da ih napadnu oni koje su zajedno s Omišanima oštetili.

Sudjelovanje, pak, u pothvatima Omišana opisano je doduše u ugovorima na različite načine (čak i kao "davanje savjeta i vijeća" u slučaju sukoba Dubrovčana i Omišana), ali je ipak jasno o čemu se radi - "Krajinjani" i "Vruljani" očito su tradicionalno sudjelovali u onim pothvatima koji su Omišane na cijelome Jadranu iznijeli na "zao glas" te od njih napravili "gusare". Iako o tomu sačuvana vrela ne otkrivaju puno, prilično je jasno da su barem tijekom 12. stoljeća, ako ne i ranije, Omišani sa svojim brodovima praktično kontrolirali plovidbu uzduž istočnojadranske obale, od Molunta do Kvarnera ali i do obala Apulije, i iz toga izvlačili takvu i toliku korist da su protiv sebe u prvim desetljećima 13. stoljeća ujedinili ni manje ni više no Veneciju, papinstvo, cara Fridrika II. te ugarsko-hrvatskoga kralja. Nakon što su, pak, 1240. godine doživjeli pravi i veliki poraz od Splićana, morali su ovima predati čak šest svojih velikih i mnogo manjih brodova, a da su odnosi Omišana i Humljana uopće, pa i njihova "zemaljskoga gospodara", u prvoj polovici 13. stoljeća bili dobri, jasno se razabire iz činjenice da su humski knezovi u pravilu, sklanjajući se pred osvajačkim pohodima srpskoga kralja, pribježišste nalazili upravo

91 Za položaj kneza Andrije tijekom 40-ih i 50-ih godina 13. stoljeća usp. M. Ančić, $N a$ rubu Zapada..., str. 153-158. 
u Omišu..$^{92}$ Brojno omiško brodovlje i široki prostor koji su s tim brodovljem njihovi vlasnici kontrolirali objašnjavaju zašto su im i kako bili potrebni i stanovnici Krajine i Vrulje, u prvome redu vjerojatno zbog pomorskih vještina, ali svakako i kao radna snaga u brodogradnji. No, upravo sudjelovanje u tim specifičnim pothvatima, koji su se uvelike razlikovali od uobičajenih aktivnosti agrarnoga svijeta istočnojadranskoga zaleđa iz kojih je izrastala i društvena organizacija, razlogom je zašto bi zaključke koji se iz ovakve raščlambe mogu izvesti ipak trebalo uzimati s određenom rezervom. Odnosi se to u prvome redu na, u ovim dokumentima izrazito vidljivu, visoku razinu samostalnosti društvenih zajednica koje su zapravo bile sastavni element složenih političkih organizama, "zemalja". Isto bi se moglo reći i za vidljivo odsustvo jasne društvene raslojenosti - svi su (valja ipak dodati: slobodni ${ }^{93}$ ) "ljudi sela Krajine" bili članovi "vijeća" i na taj način "braća", no raščlanjeni dokumenti ipak ukazuju (poglavito ako se prihvati postavka o istovjetnosti kategorija maiores i "didići") na postojanje nasljednoga prava na neki oblik (javne) "vlasti".
Ako su dakle društvene zajednice poput "sela Krajine" tvorile sastavne elemente teritorijalne i političke organizacije na sljedećoj razini, onoj "zemlje", valja ipak upozoriti kako su ishodište takvih širih zajednica, koje se gubi u tami svijeta usmene kulture, u velikom broju slučajeva bile etničke grupacije. No, kako je riječ o političkim zajednicama u živom i dinamičnom suodnosu (s izrazitom tendencijom okrupnjavanja, odnosno stalnoga smanjivanja broja zajednica) to vremenom etnicitet (kao sklop praksi uporabe i manipulacije simbolima) postaje jedna vrst simboličkoga kapitala s kojim se ulazi u društvene transakcije. (Samo polazeći iz takvih postavki moguće je primjerice objašnjavati kako je i zašto pojam "Srblji", kojim su u najstarijim ispravama bosanskih banova do sredine 13. stoljeća označavani njihovi podanici, kasnije, u 14. stoljeću, zamijenjen izričajem "Bošnjani". Teritorij prvotne Bosne, planinsko područje između gornjega i srednjega porječja istoimene rijeke i Drine na istoku, utopio se, poglavito razvojem prilika u 14 . stoljeću, u mnogo širu političku tvorbu pod vlašću vladara kojemu je ostala oznaka

92 O Omišu u 12. i 13. stoljeću, pa i vezama s Humom, vidi: M. Ančić, "Srednjovjekovni Omiš", u: Žarko Domljan (ur.), Omiš i Poljica, Naklada Ljevak, Zagreb, 2006., str. 49 i d. s nešto drugačijim pogledom od onoga uobičajenog u historiografiji.

93 Za kategoriju "neslobodnih" ljudi, vidljivu primjerice u Povaljskoj listini, odnosno "montaneju" samostana sv. Ivana u Povljima na Braču, u koji je uklopljena i "listina", ali ne i u ovdje raščlanjenim dokumentima (što je rezultat činjenice da se njima bilježi krajnje specifični sklop odnosa i obveza u kojima ti neslobodni ionako nisu participirali), vidi: Lujo Margetić, "Neka pitanja Povaljske listine", u: Archaeologia Adriatica, 2, Zadar, 2008., str. 617-618. Iako u citiranoj raspravi Lujo Margetić donosi prilično iscrpan pogled na raniju literaturu o "listini", vrijedi ipak upozoriti i na kratki ali informativni tekst Slavka Kovačića (Slavko Kovačıć, "Povaljska listina i Povaljski prag", u: Crkva u svijetu, 19, Split, 4/1984.) koji govori o samostanskome "kartularu" iako je, prema srednjovjekovnim shvaćanjima, ispravnije govoriti o "montaneju" (za tu kategoriju srednjovjekovnih vrela vidi: M. Ančıć, "Srednjovjekovni montaneji", u: Starohrvatska prosvjeta, III. ser., 24, Split, 1997.). 
"bosanskoga" bana. U tim okolnostima pod vlašću dinastije našle su se nove populacije, kojima je srpska etnička oznaka očito bila strana, dok je istodobno sa srpskim vladarima preko Drine postojao gotovo trajni odnos suprotnosti i neprijateljstva, kojemu su svakako doprinosile i vjerske razlike, jer su Kotromanići bili i ostali katolici. Sve je to stvaralo pritisak na diskurs političkoga središta. Teško je primjerice povjerovati da bi donjokrajski Hrvatinići, koji su hrvatski etnonim koristili i kao osobno ime, prihvatili da ih njihov vladar naziva "Srbljima", a oni su, ako ne već najmoćniji, a ono svakako među najmoćnijim rodovskim zajednicama proširene "Bosne". Ovakav razvoj u političkome središtu nije naravno značio, po nekoj vrsti automatizma, promjenu etničke svijesti u dubini tek površno integriranoga društva, tamo gdje je diskurs već oblikovanoga političkog središta zbog rijetke naseljenosti i komunikacijske neprohodnosti ionako teško dopirao, pa valja pretpostaviti, unatoč posvemašnjem nedostatku vrela koja bi o tome govorila, da je srpska etnička oznaka neometano nastavila funkcionirati na najvećem dijelu izvorne "zemlje Bosne".) Kad uporaba pisane riječi počne uzimati maha u društvenome životu i kad se "zemlje" pojavljuju pred očima modernoga povjesničara, a to je 12. stoljeće, njihova je struktura dograđena vlašću lokalnih dinastija, koje kroz međusobno natjecanje ali i fizičku eliminaciju uspijevaju staviti više "zemalja" pod svoju vlast, čime se stvaraju uvjeti za oblikovanje države.

Upravo se, međutim, u toj fazi utjecaj koji je dolazio iz Ugarske pokazao presudnim, o čemu najrječitije, u nedostatku pisanih vrela koja bi detaljnije osvijetlila zbivanja, pokazuje usvajanje pojma ország u inačicama "rusag", "orsag" itd. Razlozi koji su vodili konfiguriranju stanja što ga je jedan njemački povjesničar svojedobno, možda i ne baš najpreciznije (poglavito iz perspektive "nacionalnih povijesti" kakve su oblikovane u 19. i 20. stoljeću), opisao pojmom "ugarske hegemonije", ${ }^{94}$ mogu se tek više ili manje uvjerljivo nagađati. Za polaznu poziciju bi se moglo uzeti stajalište Josipa Paulera, mađarskoga povjesničara druge polovice 19. stoljeća koji se među prvima pozabavio problemom odnosa ugarsko-hrvatskih kraljeva i Bosne, i ustvrdio kako "Mađari" u Bosni nisu zatekli nikakve državne organizacije. ${ }^{95}$ Stajalište Paulera je u kasnijim vremenima, poglavito među hrvatskim, srpskim a onda i bošnjačkim povjesničarima $s$ indignacijom odbijano, jer je očito (i barem donekle s pravom) shvaćano kao neka vrst uvrjede i (danas bi se reklo) jedna vrst "kolonijalnoga diskursa". Nevolja s tim i takvim pristupom jest međutim činjenica da se povijesni razvoj

94 Georg Stadtmüler, "Ungarns Balkan-politik im zwölften und dreizehnten jahrhundert", u: Josef Gerhard Farkas (ur.), Uberliferung und Auftrag. Festschrift für Michael de Ferdinandy, Verlag Pressler, Wiesbaden, 1972.

95 Paulerov je članak objavljen na mađarskom, njemačkom i hrvatskom jeziku te je vrlo često citiran, a ovdašnjega čitatelja upućujem na ovu posljednju verziju tiskanu kao: Josip Pauler, "Kako je i kada Bosna pripala Ugarskoj", u: Glasnik zemaljskog muzeja, Sarajevo, 2/1890. 
sagledavao iz perspektive nacionalne povijesti u kojoj je "nacija" povijesni akter, pa je i proces "izgradnje države" promatran kao kolektivno djelo te iste "nacije". No, napusti li se to očište u korist onoga iz kojeg se proces promatra kao izgradnja ne "nacionalne", nego dinastičke države, odnosno (nad)države, stvari će već izgledati posve drugačije. Nakon godine 1000. i vremena vladavine kralja sv. Stjepana nije teško jasno raspoznati nagli rast moći kraljevskoga središta i razvoj funkcija koje se uobičajeno povezuju s izgradnjom države, ${ }^{96}$ pa i one dinastičke: održavanje nutarnjega reda (izgradnja utvrda i uspostavljanje županijskoga sustava, kao i uspostava kršćanskoga kulta i njegovo uređenje te susljedno definiranje crkvene organizacije); vojnička obrana/ agresija (najvidljivije u širenju kraljevskoga autoriteta na prostor istočno od srednjega toka Dunava, uključujući i pripajanje Transilvanije); održavanje komunikacijske infrastrukture (ovdje poglavitu važnost svakako ima početak kovanja vlastitoga novca); ekonomska redistribucija (koja se najizrazitije zrcali u stvaranju velikih posjeda pripadnika rodovske aristokracije kroz vladarske nadarbine). ${ }^{97} \mathrm{U}$ tome su procesu znatnu ulogu imale i pridošlice iz zapadne Europe, poglavito klerici (koji su odigrali ključnu ulogu u razvoju pismenosti, kao jed- noga od najvažnijih oruđa uspostave nadzora i autoriteta političkoga središta) i njemački vitezovi koji su dolazili sa svojom vojničkom pratnjom i bitno utjecali na transformaciju vojničke organizacije i načina ratovanja (od 108 velikaških rodova koje je oko 1285. pobrojao u svome djelu kroničar Šimun Kézai, njih četrdesetak bili su potomci "pridošlica" - advenae, ${ }^{98}$ što samo po sebi dovoljno jasno govori o značenju te pojave). Sve je ovo predstavljalo komparativnu prednost u odnosu na društva i zajednice ("zemlje") koje su oblikovane u južnom, "balkanskom" susjedstvu Kraljevstva nasljednika sv. Stjepana, te se tako postupno stvarala asimetrija moći (uspješnija mobilizacija resursa pretvarala se jednostavno u praktičnu nadmoć). To bi bila stvarna podloga Paulerova stajališta o "nepostojanju države", stajališta koje bi se primjerenije moglo iskazati izričajem o transformaciji asimetrije moći u asimetričnu političku konstrukciju, čime su stvoreni preduvjeti za susljedno oblikovanje dinastičke (nad)države. Cijeli se proces na pojavnoj razini može pratiti kroz postupnu uspostavu nadzora a potom i vlasti kraljeva Ladislava i Kolomana nad Hrvatskim Kraljevstvom na samome kraju 11. stoljeća, što je vodilo do Kolomanove krunidbe hrvatskom krunom u Biogradu 1102. godine. Kako je i u ko-

96 Vidi: Michael Mann, "The Autonomous Power of State: Its Origins, Mechanisms and Results", u: John A. Hall (ur.), States in History, Blackwell, Oxford, 1986., str. 120121.

97 Sve su ove procese mađarski povjesničari podrobno istražili, a njihove rezultate, $s$ pozivom na najvažnija djela, pregledno i razložno sumira Nora Berend (usp. Nora Berend - Przemyseaw Urbańczyx - Przemyseaw Wiszewski, Central Europe in the High Middle Ages: Bohemia, Hungary and Poland c. 900-c. 1300, Cambridge University Press, Cambridge, 2013., str. 125-137, 147-160, 163-164, 176-181, 189-194, 201-205).

98 Usp. P. Engel, The Realm..., str. 85, 122. 
jim okolnostima uspostavljena neka vrst nadzora a onda i vlasti nad "zemljama" Ramom, Bosnom, Usorom i Soli, ostaje nepoznanicom, no pojava Rame u tituli ugarsko-hrvatskih kraljeva od 1135. godine ${ }^{99}$ te nešto kasnije (potkraj života i vladavine Bele II.) instaliranje kraljeva sina kao ducis Bosne, bez obzira na već uočenu činjenicu da je tu bilo riječi o poglavito ritualnome činu, ipak jasno daju do znanja da je tijekom 30 -ih godina 12 . stoljeća ugarsko političko središte na tome području ostvarilo prevlast koja će se onda održavati stoljećima.

Ono što se ne može znati jest odgovor na pitanje jesu li sve ove "zemlje" u ovo doba imale svoje zasebne dinastije i vladare, ili su već imale jedinstvenu dinastiju, kao što se ne može znati ni je li u tim "zemljama", odnosno bilo kojoj od njih postojala banska titula, ili je i ona rezultat uspostave vrhovne vlasti ugarsko-hrvatskoga kralja. Razloge za postavljanje takva pitanja pruža primjer Usore, kojom je još u prvoj polovici 13. stoljeća vladao knez, Sibislav, koji je pripadao vladajućoj dinastiji bosanskih banova (pretpostavljenih potomaka "Kotromana Gota") te, po svemu sudeći, kao pripadnik dinastije upravljao i vladao jednom od "zemalja" pod vlašću "velikoga bana". ${ }^{100}$ Jedino što je u svemu ovome prilično jasno

99 Prvi se put Rama pojavljuje u tituli u ispravi što ju je napisao pisar kraljevske kancelarije i ovjerio pečatom kralja Bele II. 1135. godine (G. FEJER, Codex diplomaticus..., II., str. 82-85), no isprava nije sačuvana u izvorniku nego tek u mnogo kasnijem prijepisu kojega, međutim, mađarski povjesničari ne smatraju sumnjivim (usp. I. SzEnTPÉTERY, Regesta..., I., str. 21, br. 59). Drugi put se Rama pojavljuje u tituli kralja Bele II. u ispravi kojom splitskome nadbiskupu 1138. godine dariva crkvu sv. Marije na solinskom otoku (DZ, II., str. 47, br. 46), koja također nije sačuvana u izvorniku nego u prijepisu iz 18. stoljeća, no koja ničim ne izaziva sumnju glede autentičnosti. S druge strane, tri isprave kralja Bele II. sačuvane u izvornoj formi (MOL DF 206809, 1135.; MOL DF 206811, 1137. te MOL DF 286216, 1138.) imaju titulu bez Rame. U potrazi za objašnjenjem ovakvoga stanja valja držati na umu da kraljevska kancelarija u prvoj polovici 12. stoljeća definitivno nije bila uređena institucija s uhodanim obrascima postupanja, a k tomu se mora dometnuti da povjesničari danas ne znaju gotovo ništa o tomu kako se, pod kojim okolnostima i na koji način uopće odlučivalo o obliku titule i njezinu korištenju pri pisanju dokumenata. Izdavanje isprava nije bila u ovo doba još uvijek uobičajena praksa (to će normirati tek 70-ih i 80-ih godina 12. stoljeća kralj Bela III. koji je donekle i uredio djelovanje kancelarije - usp. LÁszló Veszprémy, "The Birth of a Structured Literacy in Hungary", u: Anna Adamska - Marco Mostert (ur.), The Development of Literate Mentalities in East Central Europe, Brepols, Turnhout, 2004., str. 163-165) pa ni izdani dokumenti nisu imali standardne forme. Čime je to moglo rezultirati ponajbolje se vidi iz odgovara kralja Gejze II. Splićanima na pismo koje su mu uputili nakon njegova uspona na kraljevski prijestol - dokument vidi u DZ, II., str. 49, br. 48. Dokument je sačuvan u izvorniku (vidi sliku prema MOL DF 290938), kraljevska titula sadrži Ramu, ali je umjesto Croacia (Crowatia, Chroatia ili slično) pojam Hrvatska napisan kao Urquatia. Uglavnom, Rama se nakon ovoga pojavljuje u svim onim slučajevima kada je u kancelariji ispisivana puna kraljevska titula (jedini je izuzetak Gejzina pisana zavjernica/ privilegij za Split iz 1142. godine - DZ, II, str. 49-50, br. 49; tu se ponavlja titula rex Hungarie, Chroatie atque Dalmatie, kakva se koristila za Gejzina oca, Belu II.), što samo potvrđuje neuređeno postupanje pisara.

100 Sibislavu se s papinske kurije piše kao Zibisclao kenesio de Woscura nato quondam Stephani bani de Bosna (DZ, IV., str. 15, br. 12 - naglasio M.A.), pa se čini više no vjerojatnim da je bio barem vrlo bliski srodnik tadašnjega "velikog bosanskog bana", Mateja 
jest činjenica da zbivanja u južnome susjedstvu, odnosno širenje prevlasti ugarsko-hrvatskoga kralja na jug od Save, nije realno imalo velikoga društvenog značenja za ugarsko političko (kraljevsko) središte. Odnosi toga središta s dvama Carstvima (Bizantskim i Svetim Rimskim), kao i odnosi s istočnim susjedima, pa čak i s vladajućom srpskom dinastijom, mnogo se jasnije ocrtavaju u sačuvanom i danas poznatome fondu vrela, pa o tomu svakako valja voditi računa. Ovdje nemam namjeru detaljnije razlagati kompleksni odnos ugarskoga kraljevskog središta i srpske vladajuće dinastije u 12. stoljeću, no okolnosti u kojima je kraljevska titula početkom 13 . stoljeća proširena dodavanjem Srbije čini se da mogu baciti više svjetla i na to kako se i zašto Rama pojavila u tituli Bele II.

Polaznu poziciju raščlambe ovdje predstavlja stanje kakvo je vladalo i kako je prilično precizno opisano u vrijeme kad je car Fridrik I. Barbarossa 1189. godine preko Ugarske i bizantskih područja putovao na križarski pohod u Svetu Zemlju. $\mathrm{U}$ opisu se toga putovanja veli kako je carska vojska, nakon što je prošla ugarsku pograničnu "marku" prema Bizantu, na današnjem području Srijema, prešla Savu tamo gdje se ona ulijeva u Dunav te se našla u "zemlji pod vlašću Grka", i da je blagdan presvetih apostola Petra i Pavla provela u "polurazrušenom grčkom" gradu Beogradu. ${ }^{101}$ Ubrzo nakon prolaska križarske vojske, krenulo je postupno osvajanje krajeva južno od Save, a središte iz kojega je polazilo to osvajanje postala je utvrda Mačva (do danas još taj lokalitet nije precizno ubiciran). Tijekom sljedećega desetljeća vlast se ugarsko-hrvatskoga kralja proširila daleko od Save na jug, dopirući gotovo do Rudnika, u današnjoj sjeverozapadnoj Srbiji, i obuhvaćajući osim već spomenutoga Beograda krajeve južno od Dunava, Braničevo i Kučevo. No, to nije bilo razlogom da kralj Emerik u svoju titulu uklopi i Srbiju (iako će se ti krajevi u kasnijim vremenima doista nazivati "Srbija" za razliku od "Raške). Do toga je naime došlo tek 1202. godine, nakon što je upravo njegovom intervencijom sukob među sinovima velikoga župana Nemanje, Vukanom i Stefanom

Ninoslava. Uz ovo svakako valja primijetiti: kad početkom 14. stoljeća braća Stjepan, Ivan i Radoslav Babonići dijele svoje goleme posjede, uključujući i ono što su stekli u "zemlji" Usori, spominju se tamošnji posjedi pojedinaca koje su im nekad darivali "pravi gospodari Usore" (veri domini de Vzura) - DZ, VIII., str. 360, br. 301, 12. 5. 1314. - što znači da je kolektivna memorija o "zemaljskoj" zasebnosti i njezinim "pravim gospodarima" (a koje se ne spominje s banskom titulom) barem u ovo doba još uvijek živa. Pojam "veliki" u banskoj tituli Mateja Ninoslava nije nikakva posebnost. Isti se lement nalazi i u titulama humskih gospodara (knez' veli hl'm'sk'i) kao i onih srpskih/raških (veli župan') te je posve izvjesno vezan uz unutardinastičke odnose i definira poziciju onoga pripadnika dinastije koji zauzima čelnu poziciju.

101 Anton Chroust (prir.), Historia de expeditione Friderici imperatoris et quidam alii rervm gestarum fontes eivsdem expeditionis. Monumenta Germaniae Historica, Scriptores rerum Germanicarum NS V, Berolini, 1928., str. 26-27: transeuntes ... Sauum seu Souuam fluvium, ubi Danubium influit ... mox in terra ditionis Grecorum sumus constituti ... Festum ipsum beatissimorum apostolorum inibi id est in litore ipsius Souue in civitate semidiruta et greca ... sollempnizavimus. 
(kasnijim prvim srpskim kraljem, pa otuda "Prvovenčani"), završen pobjedom onoga prvog i njegovim (doduše kratkotrajnim) preuzimanjem svih "zemalja" nad kojima je dinastija već odranije imala vlast. ${ }^{102}$ Ako je dakle suditi prema ovome primjeru, a nema razloga koji bi govorio protiv toga, upravo je čin postavljanja vladara "zemlje" bio onaj odlučni trenutak od kojega se smatralo kako se određena "zemlja" (ili sklop "zemalja" pod jednom dinastičkom vlašću) nalazi pod vlašću kralja u toj mjeri da je se može unijeti u titulu. To bi pak značilo da je u prvoj polovici 30-ih godina 12 . stoljeća upravo to bilo ostvareno u Rami te da je "zemlja" nakon toga ušla u kraljevsku titulu.

Što je, pak, značilo takvo uspostavljanje kontrole nad vladarom "zemlje" ili sklopa "zemalja"? Odgovor na taj upit trebao bi poći od činjenice koja se često naglašava u literaturi, a to je da predmoderni vladari, u odsustvu dobrih komunikacija, nemaju načina vladati udaljenijim krajevima drugačije nego preko lokalnih moćnika kao posrednika koji su im izravno podčinjeni, ali koji na određenome prostoru onda gotovo samostalno vladaju te organiziraju to vladanje kao vlastito dinastičko "kućanstvo". ${ }^{103}$ Njihova se podčinjenost, a tu dolazimo na područje ranije označeno kao "slike u glavama", područje shema i stereotipa kroz koje se organiziralo znanje o svijetu, iskazuje pojmom "vern'i klet'venik'"104 i ogleda prije svega u redovitom isplaćivanju neke vrsti tributa, vojnoj pomoći u okolnostima kad ona zatreba i sudjelovanju u ritualnim činima u političkom središtu koji na simboličan način pokazuju tu podčinjenost. Izostanak bilo kojega od ovih elemenata tumači se kao neposluh i obično je povod za kaznenu ekspediciju. Cilj takvih ekspedicija, koje na području južno od Save i istočno od Vrbasa zbog fizičkih predispozicija (planinski, slabo prohodni i relativno siromašni krajevi) nisu ni mogle biti zamišljene, a kamoli ostvarene kao dugotrajni pohodi velikih snaga, nije bio fizička eliminacija, odnosno uklanjanje neposlušnika, nego uspostavljanje ranije postojećih odnosa.

Upravo iz ovakvoga konteksta valja promatrati tzv. "križarske vojne" protiv "bosanskih heretika" iz 20-ih i 30-ih godina 13. stoljeća, za koje sam

102 O složenom kolopletu ratnih pohoda i s njima povezanih dinastičkih saveza i prijepora ni danas se ne zna mnogo više no što je bio u stanju napisati prije više od stotinu godina Konstantin Jireček (Konstantin Jirečex, Istorija Srba, I., Naučna knjiga, Beograd, 1952., str. 210-212; usp. i Jovanka Kalić, Beograd u srednjem veku, Srpska književna zadruga, Beograd, 1967., str. 57-58). Prva isprava u kojoj Emerik koristi proširenu titulu datirana je samo 1202. godinom (MOL DF 258191).

103 Usp. G. E. Aymler, "Centre and Locality...", str. 66; M. Mann, "The Autonomous...", str. 124.

104 U ugovoru između dubrovačke općine i humskoga župana Radoslava od 22. svibnja 1254. za ovoga se, u prvome licu, veli "ja župan' Radoslav' sem' verni klet'venik' gospodinu kraljo uger'skomu" (LJ. StojAnović, Stare srpske povelje ..., str. 26, br. 27). Na drugoj strani te veze odnos se ugarsko-hrvatskoga kralja i bosanskoga bana opisuje, dakako u latinskom izričaju, kao "nama dužna vjernost" (debita nobis fidelitas - DZ, IV., str. 349, br. 313, 22. 4. 1244.). 
već ranije ustvrdio kako su zapravo literarna fikcija stvorena u prepisci između papinske kurije i ugarskohrvatskih vladara i njihovih prelata, prepisci kroz koju je papinska kurija nastojala materijalizirati prerogative što ih je sama prisvojila u vremenu nakon pontifikata Grgura VII. ${ }^{105} \mathrm{Ov}$ dje bih tome dodao dvije stvari - vezivanje Bosne, kao sklopa "zemalja", s područjima južno do Save ("Srbija") prema sad već Raškom Kraljevstvu, područjima koja se $s$ ugarske strane ponekad nazivaju i "Donji Srijem", počelo je čini se upravo u svezi s (fiktivnom) organizacijom "križarskih pohoda" protiv "bosanskih heretika". Prvi put su bosanska banovina i "Srijem" spojeni u neku vrst administrativne jedinice kada je kaločki nadbiskup 1225. godine, kao titularni posjednik "zemalja" Bosne, Usore i Soli, vođenje pohoda protiv "heretika" povjerio princu Ivanu (Kalojanu) Anđelu, koji je već upravljao "Donjim Srijemom", pa se čini vjerojatnim da je upravo na toj tradiciji oblikovan i "dukat" Rostislava Mihailoviča, s kojim je ovo razglabanje i započeto.

Druga stvar na koju bih upozorio odnosi se na često u historiografiji ponavljanu tvrdnju prema kojoj su "križarski pohodi" protiv "bosanskih heretika" prve polovice 13. stoljeća bili zapravo tek opravdanje za pokušaje ugarsko-hrvatskih vladara da "pokore Bosnu". Nisam mogao utvrditi tko je i kada prvi put formulirao takvu postavku, no vrijedi ovdje svakako jasno i glasno reći: takva misaona konstrukcija razumljiva je i prihvatljiva samo ako se polazi iz mentalnoga koncepta ("slike u gla- vi") koji podrazumijeva svijet uređen kao sustar suverenih država, i to u onoj modernoj varijanti s multilateralnim organizacijama poput Lige naroda ili Ujedinjenih naroda. U tome je i takvom svijetu doista potrebno naći opravdanje pri posezanju za "tuđim" teritorijem ili za fizičku/ vojnu intervenciju na teritoriju druge suverene države. Takva međutim misaona konstrukcija posve je strana govori li se o srednjovjekovnom svijetu, pa je prvo pitanje koje se odmah nameće ono: kome su se to ugarskohrvatski vladari trebali "pravdati" ako su htjeli "pokoriti Bosnu"? Odgovora na tako postavljeno pitanje nema i ne može biti, jer su odnosi u svijetu dinastičkih država počivali na posve različitim premisama, što sam na prethodnim stranicama nastojao pokazati i dokazati.

Cijelo prethodno razlaganje prilika i odnosa u 12. i 13. stoljeću počiva na veoma slabašnim pisanim tragovima koji otvaraju široki spektar mogućih interpretacija i ne osiguravaju pouzdano zaključivanje. Stvari ne stoje puno bolje ni kada se govori o 14. stoljeću, ili barem njegovu većem dijelu, no količina sačuvanih pisanih tragova, vrela koja za svoje spoznaje koriste povjesničari, počinje naglo rasti kako se bliži kraj toga stoljeća. Pouzdan je to znak da je medij pisane komunikacije dobivao na društvenom značenju, odnosno da je sve više društvenih odnosa trebalo fiksirati pisanom riječju. Odnosi koji su se ranije uspostavljali izgovorenom riječju i na određeni način fiksirali i reproducirali ritual- 
nim činima, sada se sve češće pretaču u pisani dokument, pri čemu ne bi trebalo zanemariti pretpostavku da je postojalo vjerovanje kako sam čin zapisivanja nameće obvezu pridržavanja u budućnosti postavljenih normi. No, pretakanje složenih društvenih odnosa u formulaične izričaje pisanoga dokumenta bilo je i na početku 15. stoljeća još uvijek rijetka pa stoga i cijenjena vještina, iz koje će nastati ono što P. Bourdieu naziva "birokratsko polje" kao važan dio procesa transformacije dinastičke u modernu, teritorijalnu državu. Kako je to u stvarnosti izgledalo može se naslutiti iz činjenice da su dubrovački poslanici pri kraju pregovora s bosanskim velikašima o zaključivanju mira 1405. godine od vlasti svoga grada tražili posebnoga "čovjeka koji zna čitati i pisati na slavenskom jeziku" kako bi mogli u potpunosti kontrolirati sadržaj "povelje" kojom je trebalo zaključiti pregovore. Općinske su im vlasti doista i poslale takvoga čovjeka, stanovitoga Franu de Georgiisa, za kojega su tvrdili da "dobro zna čitati i pisati". ${ }^{106}$ Nije to naravno značilo da su svi ritualni čini automatski izgubili svoju društvenu važnost, kako se dade razabrati iz situacije nastale kada je veliki vojvoda Sandalj predao dubrovačkim vlastima utvrdu Sokol iz koje se moglo nadzirati Konavle, polovicu kojih su od njega i kupili. Sam čin predaje proveden je ritual- nim uvođenjem u posjed predstavnika dubrovaćke općine po Sandaljevim izaslanicima, a kada su gradske vlasti tražile da se o tomu sastavi i poseban dokument, "povelja", bosanski je vojvoda to jednostavno odbio, smatrajući kako je posao završen samim činom uvođenja u posjed. ${ }^{107}$

No, nije samo rast značenja pisanoga dokumenta ono što je obilježilo vrijeme prijeloma 14 . i 15 . stoljeća. U isto doba, i nedvojbeno vezano uz to, počinje se zamjećivati u društvenoj komunikaciji i novo i drugačije konceptualiziranje prostora, koji se također počinje vizualizirati u dvodimenzionalnoj slici. Prvi sačuvani zemljovid barem jednoga dijela $A r$ chiregnuma Hungaricuma potječe upravo iz prvih desetljeća 15 . stoljeća i dao ga je izraditi poznati službenik i kasnije vojskovođa tadašnjega ugarsko-hrvatskoga kralja Sigismunda Luksemburškoga, Filip Pipo Scolari, a prikazivao je upravo ono područje, južno od Save i Dunava, na kojemu je Pipo sam trebao urediti sustav obrane od Turaka popravkom starih i izgradnjom novih utvrda. ${ }^{108}$

Sve je ovo trebalo naznačiti kako bi se razumjelo zašto upravo od ovoga vremena slika prilika i odnosa unutar još uvijek dinastičke (nad)države postaje mnogo izoštrenija i jasnija, što automatski znači i da se puno više zna o poziciji Bosanskoga Kra-

106 Izričaji una persona che sapia leger et scriuer in sclauonesco, te el sa ben leger e scriuer potječu iz pisma što su ga općinske vlasti uputile svojim poslanicima 21. svibnja 1405., a kojega izvadak reproducira E. Kurtović, Veliki vojvoda..., str. 152 bilj. 515.

107 Isto, str. 243.

108 Za naručitelja i okolnosti izrade zemljovida vidi: LÁszLó Gróf, "Cartography at the time of Sigismund of Luxemburg (1368-1437)", u: István Petrovics et al. (ur.), "In my spirit and thought I remained a European of Hungarian origin": Medieval Historical Studies in Memory of Zoltan J. Kosztolnyik, JATE Press, Szeged, 2010. 
ljevstva unutar toga sustava. Ovdje, pak, ocrtani kontekst treba u prvome redu objasniti jedan sklop činjenica koji je već bio predmetom povjesničarskih raščlambi, naime postupak tijekom kojega je, na zahtjev koji je došao iz Bosne, pretendent na krunu sv. Stjepana, a za mnoge suvremenike i legitimni ugarsko-hrvatski kralj, Ladislav Napuljski, potvrdio stare običaje i granice Bosanskoga Kraljevstva posebnim privilegijem izdanim 26. kolovoza 1406. ${ }^{109}$ Traženje bosanske strane i samo izdavanje ovoga posebnog privilegija često je spominjano $\mathrm{u}$ velikom broju različitih povjesničarskih tekstova posvećenih burnim zbivanjima na dubokome prostoru istočnojadranskoga zaleđa početkom 15. stoljeća, pri čemu je uobičajeno dovođeno u svezu s ofenzivnim vojnim operacijama koje je u ovo doba poduzimao ugarsko-hrvatski kralj Sigismund Luksemburški. ${ }^{110}$ No, tek je Pejo Ćošković prije petnaestak godina posvetio cijelu raspravu raščlambi okolnosti pod kojima je došlo do nastanka privilegija/potvrdnice, ${ }^{111}$ i to u klasičnome duhu patriotske historiografije s nedostatnim istraživačkim zahvatom i s polaznim pozicijama koje djeluju više no zbunjujuće. Ćošković, naime, svoju raspravu otvara nizom tvrdnji o "državnim granicama" i "državnom suverenitetu" kao bezvremenskim kategorija- ma i zaključkom po kojemu "nema bitne razlike u povijesnim procesima s obzirom na postupke i posljedice po pojedinim razdobljima, geografskim prostorima pa i konkretnim državnim, vladarskim i podaničkim sudbinama".112 No, samo nekoliko rečenica dalje ustvrđuje nešto posve suprotno: "(p)oimanja srednjovjekovnog društva o mnogim pitanjima nerijetko su u toj mjeri različita od današnjih da mogu zbuniti ne samo zainteresirane čitatelje nego i same istraživače jer ne odgovaraju našim shvaćanjima i sustavima vrijednosti. Ta primjedba podjednako vrijedi i za pitanja kojima smo u ovom radu kanili pokloniti posebnu pozornost, a tiču se promjene državnih granica, njihova utvrđivanja i potvrđivanja". ${ }^{113}$ Naravno, "zainteresirani čitatelj" već na početku ostaje zbunjen upravo ovim - ako postoje razlike shvaćanja određenih stvari i pojava u različitim vremenima i na različitim prostorima kako to onda "nema bitne razlike u povijesnim procesima... po pojedinim razdobljima, geografskim prostorima"? Ako je čitatelj ostao zbunjen ovako postavljenim početnim pozicijama, sam "istraživač" je slične prepreke uspješno "preskočio" te je svojim "istraživanjem" uspio složiti preciznu narativnu okosnicu uzročno-posljedičnog objašnjenja zahtjeva za potvrdom, kako on to veli, "držav-

109 Isprava što ju je izdala kancelarija kralja Ladislava Napuljskog tiskana je u: G. Fejer, Codex diplomaticus..., X./4, str. 549-551.

110 Samo kao najnovije primjere vidi: D. Lovrenović, Na klizištu povijesti..., str. 130, te: E. Kurtović, Veliki vojvoda..., str. 162.

111 Pejo ĆošKović, "Bosna na prijelomu stoljeća i potvrda državnih granica 1406. godine", u: Prilozi, 31, Sarajevo, 2002., str. 64 i d.

112 Isto, str. 57.

113 Isto, str. 57-58. 
nih granica". ${ }^{114} \mathrm{Tu}$ njegovu narativnu okosnicu tvori zapravo tek jedan dokument - kako on veli Sigismundovo pismo "koje je 10. lipnja 1405. uputio sucima i stanovništvu grada Prešova (Eperjes), tražeći od njih da mu po Simonu Rozgonyju pošalju 500 forinti". Važnost toga "pisma" za Ćoškovića je u činjenici da u njemu Sigismund obznanjuje svoju namjeru "krenuti protiv 'svoje kraljevine Rame ili Bosne' da bi prema njima ispravio i obnovio državne granice".115 Taj izričaj o "ispravljanju i obnavljanju državne granice" ključni je element Ćoškovićeve naracije, jer se na njega nadovezuje djelovanje "Bošnjana" koji "su ozbiljno shvatili Sigismundove najave o ispravljanju i promjenama državnih granica prema Bosni", pa su se (navodno) u proljeće 1406. okupili na saboru. Iako se koristi klasičnim historiografskim iskazom, "kako se saznaje" da bi objasnio što se događalo na saboru, ${ }^{116}$ Ćošković ne otkriva odakle se to "saznaje", jer to ni ne može, budući da ne postoji nikakav pisani trag o radu toga sabora, pa čak ni o tome je li uopće održan.
Cijela romaneskna pripovijest o Sigismundovu nastojanju na promjeni "državnih granica" i reakcijama Bošnjana u obrani svoga "državnog suvereniteta" zapravo je obična izmišljotina u duhu patriotske historiografije 19. stoljeća. Kraljevo "pismo" građanima Prešova od 10. lipnja 1405. zapravo je okružnica od koje su sačuvana dva primjerka (koliko ih je stvarno bilo teško je i pretpostaviti) - jedan ovaj na koji se poziva Ćošković, dok je drugi primjerak, datiran u kraljevskoj kancelariji 9. lipnja sačuvan u arhivu grada Košica (danas u Slovačkoj), što bi znao i P. Ćošković da je doista pogledao publikaciju na koju se poziva, diplomatarij Sigismundova vremena koji je priredio mađarski povjesničar Elemér Mályusz. ${ }^{117}$ Povezati, pak, u jedan narativni slijed sadržaj okružnice kojom kralj traži novac za svoj vojni pohod (od oba grada je tražio 500 zlatnih dukata), objašnjen uopćenom tvrdnjom o ispravljanju i obnovi granica Bosanskoga Kraljevstva, $s$ u najmanju ruku pretpostavljenim ako ne već i izmišljenim saborom koji je navodno održan deset mjeseci ka-

114 Vrijedi svakako uočiti da Ćošković smatra kako je jedan od najvažnijih zadataka povjesničara "procese objasni(ti) u uzročno-posljedičnoj uzajamnosti" - Isto, str. 57.

115 Isto, str. 69.

116 Isto, str. 71.

117 Podatci o sačuvanim primjercima okružnice s istovjetnim uvodnim tekstom o planiranome pohodu, is različitim naputcima o načinu isplate i nadoknade novca te različitim datumima njezina slanja iz kraljevske kancelarije, u: Elemér Mályusz, Zsigmondkori oklevéltár, II./1, Akadémiai Kiadó, Budapest, 1956., str. 483, br. 3956, 9. 6. 1405. i br. 3962, 10. 6. 1405. Ćošković uza svoje navode citira diplomatarij (P. ĆošKović, "Bosna na prijelomu...", str. 71, bilj. 42 i 43), ali samo brojem stranice a ne i brojem dokumenta, po čemu se dade zaključiti da djelo zapravo nije ni vidio, jer bi inače, valjda, primijetio da se vrlo sličan dokument pojavljuje pod drugim brojem i datumom na istoj stranici. Usporedbom fotografija oba dokumenta (MOL DF 270083 i MOL DF 287056) postaje vidljivo da su pisani različitim rukama, očito kao serijski proizvodi kancelarijske produkcije. 
snije, odnosno sa zahtjevom upućenim iz Bosne u Napulj više od godinu dana nakon slanja Sigismundovih okružnica, i to samo zato što se u obje instance spominju "granice", jednostavno je neozbiljan i nedopustiv postupak. Isto je tako neozbiljno u ovim dokumentima spomenute "granice" (confinia et metae) jednostavno pretvarati u "državne granice" bez ikakva objašnjenja, kao da je postojanje tih "državnih granica" samorazumljiva stvar.

No, dokumenti na kojima Ćošković gradi svoju patriotski nadahnjujuću pripovijest (srednjovjekovni Bošnjani su, njegova je poruka, itekako vodili računa o "granicama svoje države") ipak su važni u raspravi o statusu Bosanskoga Kraljevstva unutar Archiregnuma. U prvome redu, Sigismundova je okružnica jedan od prvih, ako ne i prvi sačuvani dokument u kojem se izjednačuju Bosna i Rama (regnum nostrum Rame seu Bozne), što je pouzdan znak da više nije riječ o starim "zemljama" objedinjenim pod jednom dinastičkom vlašću nego o jedinstvenom političkom prostoru Kraljevstva, kojega doduše Sigismund smatra "svojim". No, to Kraljevstvo smatraju dijelom političke cjeline kojom vlada onaj tko raspolaže "krunom sv. Stjepana" i sami Bošnjani, koji međutim ne smatraju Sigismunda legitimnim vladarom i nositeljem te krune, pa se zato za potvrdu svojih prava, običaja i granica obraćaju onome koga oni smatraju legitimnim vladarom, a to je po njima Ladislav Napuljski. Kako bosanski kralj, u ovoj situaciji je to
Tvrtko II. Tvrtković, i njegovi velikaši, a poimence su navedeni samo splitski herceg i donjokrajski knez Hrvoje te veliki vojvoda Bosanskoga Kraljevstva Sandalj, odnosno baruni i prvaci kao i cijela zajednica Kraljevstva, doživljavaju i shvaćaju to svoje Kraljevstvo, vrlo je teško razabrati iz dokumenta sastavljenoga u Napulju. Iako se u samome dokumentu navodi kako je Ladislav potvrdio sve što su tražili bosanski izaslanici, a u latinskome izričaju to glasi: omnes et singulas consuetudines, statum, et iura antiquitus eis obseruatas, et obseruata, nec non confinia et metas ipsius Regni Boznae, possessa et possessas, per quondam spectabilem Culin, olim dicti regni Boznae Banum, ${ }^{118}$ ipak nije tako jednostavno razaznati je li se ovdje nešto "izgubilo u prijevodu". Pojmovi consuetudines i iura, "običaji" i "prava", u tome smislu nisu nimalo problematični, a latinska konstrukcija rečenice i pretpostavljeni smisao traži da zamjenica eis ovdje stoji u ablativu množine, što znači da se potvrđuju "običaji i prava" kojih su se oni (svi pobrojani) u Bosanskome Kraljevstvu "od starine" (antiquitus) pridržavali. Problemi, međutim, nastaju s pojmom statum kad se on poveže uz Regnum Boznae. U pravnoj kulturi u kojoj su obrazovani činovnici napuljskoga dvora, koji su i sastavili dokument, taj je pojam bio sinoniman pojmovima potestas, regimen, gubernatio (moć, vlada, upravljanje) te je imao "smisao političkoga režima" kao začetka modernoga pojma "države" koju ostvaruje zajednica vladara i njegovih podanika. ${ }^{119}$ Jesu li bosanski izaslanici tražili potvrdu

118 G. Fejer, Codex diplomaticus..., X./4, str. 449.

119 Vidi o tome: B. GuenéE, States and Rulers..., str. 5. 
"državne zasebnosti" svoga Kraljevstva teško je reći, odnosno teško je i naslutiti koji su od njihovih zahtjeva činovnici napuljske kancelarije razumjeli na takav način da su ga preveli sa statum ... Regni Boznae. Najbliže što se u poznatome materijalu vrela može naći takvu izričaju jest formulacija iz privilegija što ga je 20. lipnja 1405. dubrovačkim vlastima ispostavila kancelarija kralja Tvrtka II., potvrđujući dogovoreni mir i posjede koje su Dubrovčani ishodili u pregovorima s bosanskim kraljem i njegovim velikašima. ${ }^{120} \mathrm{Na}$ jednom mjestu u tome privilegiju pojavljuje se izričaj: "tko godi e Boš'nanin' ali kralstva bosan'skoga", ${ }^{121}$ kojim se opisuju svi podanici Bosanskoga Kraljevstva, ali ostaje otvoreno pitanje jesu li u svijesti, barem pripadnika onoga vladajućeg sloja, svi ti podanici Kraljevstva tvorili jedinstvenu i zasebnu cjelinu, "politički režim", s kraljem i njegovim velikašima? Prisjetimo li se ovdje načina na koji je svoju ulogu opisivao u ovo doba kralj Ostoja, a o čemu je bilo riječi na početku, teško bi bilo prihvatiti takvu mogućnost. Kakav god, međutim, odgovor na to pitanje bio, ${ }^{122}$ on ne mijenja činjenicu da su sami Bošnjani vidjeli svoje Kraljevstvo, da se izrazim slikovito, pod krunom sv. Stjepana.

Bez te početne premise, zapravo izravne eksplikacije onoga što sam označio kao "slike u glavama", ni traženje potvrde "običaja i prava", pa eventualno čak i statusa ... regni u Napulju ne bi zapravo imalo nikakva smisla. No, nije svako djelovanje informirano "slikama u glavi" imalo isti tijek, učinak i ishod. Okolnosti pod kojima je tražena a potom i dobivena potvrda u Napulju 1406. godine posve su nejasne, pa se stoga valja okrenuti nekoj od povijesnih situacija koje su, zahvaljujući sačuvanim vrelima, bolje poznate te se onda kroz detaljniju raščlambu takve situacije može preciznije ogledati odnos između "slika u glavama" i praktičnoga djelovanja. Jednu takvu situaciju moguće je naći u onih nekoliko mjeseci nakon smrti velikoga vojvode Bosanskoga Kraljevstva, Sandalja Hranića, kad je njegov nećak i nasljednik, budući herceg Stipan (tako u pravilu u ovo doba dubrovački dokumenti bilježe njegovo ime) Vukčić Kosača, nastojao očuvati naslijeđene posjede. Za potrebe raščlambe u ovome ću se slučaju

120 O dugotrajnim i na trenutke mučnim pregovorima koji su prethodili izdavanju privilegija posljednji je opširno pisao E. KurTović, Veliki vojvoda..., str. 137 i d.

121 LJ. Stojanović, Stare srpske povelje..., I., str. 493, br. 513.

122 Jedino što je ovdje doista posve izvjesno jest spoznaja da u ovo vrijeme pojam "država" još uvijek nema one konotacije koje će kasnije dobiti. Kada 1419. godine veliki vojvoda bosanski izdaje dokument kojim registrira čin ustupanja (prodaje) svoga dijela Konavala Dubrovčanima onda se u tome dokumentu veli: "Mi ... Sandal' Hranić' ... budući va velikoi slavi i gospoctvi i državi moih' praroditel' plemenito naše" (LJ. STojanović, Stare srpske povelje..., I., str. 293, br. 314, 24. 6. 1419.). "Država" je dakle još uvijek ono što netko "drži", vlasništvo, pa je eventualna svijest o "zasebnoj državnosti" Kraljevstva mogla eventualno biti iskazana tek pojmom "rusag" i vezana uz prava dinastije Kotromanića. Takvo tumačenje, naime, ima snažnu potporu u činjenici da bosansko plemstvo nikako nije bilo spremno prihvatiti Sigismundovu ideju da ga se u posebnome ritualu okruni za bosanskoga kralja. 
ograničiti samo na jedan segment tih složenih zbivanja, na pokušaj da se iz sklopa Sandaljevih posjeda izdvoji stara politička tvorba, Humsko Kneštvo, i dodijeli jednome od najvjernijih Sigismundovih službenika, Matku Talovcu. Raščlamba bi, pak, trebala funkcionirati na tri razine - na prvoj razini ona eksplicira model odnosa političkoga "središta" i onoga što se u tome kontekstu može nazvati "periferijom", model koji je teorijski postavljen na početku ovih razmatranja. $\mathrm{Na}$ drugoj razini nastojat ću, kako je već rečeno, prikazati na koji su način "slike u glavama", sa svim razlikama koje je podrazumijevalo pozicioniranje pojedinca ili pripadnika zajednice koja dijele takve "slike" u društvenim odnosima, bile ishodište praktičnoga djelovanja. $\mathrm{Na}$ trećoj razini naracija i interpretacija su postavljene kao kontrapunkt historiografskome pristupu kakav obilježava cijelu produkciju ("beogradsko-sarajevske škole") koju predstavlja na početku ove rasprave raščlanjeno djelo D. Lovrenovića.

Zbivanja u vremenskome rasponu od 15. ožujka (Sandaljeve smrti) do kraja kolovoza 1435. (kad je postalo posve jasno da od plana oblikovanoga na Sigismundovu dvoru ne će biti ništa) već su privukla pozornost povjesničara. No, nitko od njih nije na žalost ni pokušao ocrtati panoramski prikaz tih zbivanja, pa su uglavnom ostali ograničeni na ono očište koje se otvara iz lokalne bosanske perspektive, što zbivanja čini praktično nerazumljivima. ${ }^{123}$ Početnu točku raščlambe predstavlja svakako posjet bosanskoga kralja Tvrtka II. caru i kralju Sigismundu u zimu 1435., tijekom kojega su dva vladara boravili u Požunu (Bratislavi) i Beču, a prvi dokument koji se može uvezati u narativnu cjelinu jest pismo što ga je iz Požuna 19. ožujka 1435. svome službeniku ("familijaru") i kaštelanu utvrde Kalnik Petru Horvatu uputio tadašnji kovin-

123 Usp. Sima Ćirković, Herceg Stefan Vukčić Kosača i njegovo doba (ćir.), SANU, Beograd, 1964., str. 10 i d., s pogledom na stariju literaturu; PAvo Živković, Tvrtko II Tortković - Bosna u prvoj polovini 15. stoljeća, Institut za istoriju u Sarajevu, Sarajevo, 1981., str. 170 i d.; Đuro Tošıć, Trg Drijeva u srednjem vijeku (ćir.), Veselin Masleša, Sarajevo, 1987., str. 140 i d.; D. Lovrenović, Na klizištu povijesti..., str. 258 i d. Iz drugačijega očišta zbivanja promatra EMIr O. Filipović, "Boravak bosanskog kralja Tvrtka II Tvrtkovića u Beču 1435. godine", Radovi: Historija, Historija umjetnosti, Arheologija, XVI./2, Sarajevo, 2012., koji uspješno prikazuje kako je bosanski kralj, posredovanjem tadašnjega cara i kralja Sigismunda, ušao u "srednjeuropsku političku arenu". Pri tomu se autor ipak ne može otresti utjecaja "patriotske" historiografije, kakav se vidi primjerice u stajalištu (str. 242) usidrenom u suvremeni politički mit o "borbi protiv tuđina": "O razlozima kraljevog povratka u zemlju također se može samo pretpostavljati. Vjerovatno shvativši da mu prisustvo ugarske vojske u njegovom kraljevstvu neće donijeti ništa korisno u dugoročnom pogledu, Tvrtko II se vratio u Bosnu gdje se izmirio sa Stjepanom Vukčićem" (naglasio M.A.). Ovako postavljeno razlaganje (opreka između "ugarske vojske", što znači prijateljstvo i suradnju sa Sigismundom, "strancem", i "izmirenja sa Stjepanom Vukčićem" koji je onda valjda "domaći" akter) posve gubi smisao uzme li se u obzir da se i Stipan Vukčić nešto kasnije "izmirio" s carem Svetoga Rimskog Carstva i ugarsko-hrvatskim kraljem Sigismundom (vidi S. Ćirković, Herceg Stefan..., str. 22), što onda nuka na posve drugačije tumačenje tih postupaka "mirenja", koji očito ne korespondiraju s "nacionalnim" ("domaći/naši" i "stranci") tumačenjem koje im se pridaje. 
ski župan i gubernator zagrebačke biskupije Matko Talovac. ${ }^{124}$

No, prije eksplikacije samoga narativnog slijeda zbivanja i njihove interpretacije valja se ipak osvrnuti na one simbolične čine koji su u stvarnosti, dakako za vrlo određeni (a relativno uski) krug promatrača i sudionika, utjelovljavali "sliku" odnosa dvaju vladara. Tvrtkov posjet Sigismundu svakako je imao mnogo elemenata političkih rituala onoga doba (dakako različitih od sklopa rituala 12 . i 13 . stoljeća o kojima je bilo riječi ranije). Bosanski je kralj zapravo u posjet krenuo kako bi ovjerio vojne i političke uspjehe postignute tijekom 1434. godine te je to bila realna pozadina ritu- ala koji se mogu tek nazrijeti. U prvome redu kralja je u Požun dopratio tadašnji kovinski župan i gubernator zagrebačke biskupije Matko Talovac, u ovo doba Sigismundov glavni pouzdanik za pitanja odnosa s Turcima, a ta se i takva njegova uloga u kasnijim vremenima posebice apostrofirala, ${ }^{125}$ iz čega se već dade iščitati elemente rituala. Po dolasku u Požun Tvrtko je posebnim činom, čije pojedinosti kao i publika ostaju nepoznanicom no koji kao cjelina smisao nalazi samo u sklopu obrasca odnosa u dinastičkoj (nad)državi, ${ }^{126}$ potvrdio svoju vjernost ugarsko-hrvatskome kralju, a ovaj ga je za nagradu poveo sa sobom u Beč, gdje se očekivalo rođenje

124 Tvrtkov posjet i boravak u Beču detaljno razlaže E. O. Filıpović, "Boravak bosanskog kralja...", str. 231 i d. Pismo, pak, Matka Talovca Petru Horvatu donosim ovdje kao Prilog I.

125 U svečanoj darovnici što ju je Sigismundova kraljevska kancelarija ispostavila Matku Talovcu 27. rujna 1437. (darovnica je tiskana u: Lajos Thallóczy - Antal Áldásy (prir.), Codex diplomaticus partium regno Hungariae adnexarum, 2, MTA, Budapest, 1907., str. 111-123, br. CLXXXIV) posebice se navodi: memoratus Mathko banus illustrem Stephanum Twertk regem scilicet Bozne pretactum simulcum baronibus et notabi...... ipsam Posonium in conspectum nostre adduxit maiestatis (Isto, str. 116; točkicama je označen dio teksta nečitljiv zbog velikoga oštećenja pergamene).

$126 \mathrm{U}$ istome se dokumentu pripovijedanje o Talovčevu dovođenju bosanskoga kralja nastavlja riječima: quem tandem regem simulcum suis baronibus et nobilibus predictis nos accepto ab eis..... [obse]rvando fidelitatis homagio (Isto, str. 116). Pojam homagium koji je ovdje uporabljen imao je vrlo široko značenje te je mogao podrazumijevati ritualne radnje sa simboličkim gestama (komendaciju, polaganje sklopljenih ruku u tuđe raširene ruke), ali i svečano polaganje prisege, no uvijek je podrazumijevao element podredenosti, kao u izričaju "prisega vjernosti i omagium podaništva" (sacramentum fidelitatis et subiectionis omagium) što su, primjerice, potvrdili članovi dubrovačkoga Velikog vijeća pred izaslanicima kraljice Marije i kralja Sigismunda 24. srpnja 1387. u Dubrovniku (dokument nastao tom prigodom s upravo citiranim izričajem tiskan je u DZ, XVII., str. 74-75, br. 57). Ritualni homagium očekivao se i od nositelja visokih dužnosti u Svetom Rimskom Carstvu, a S. Reynolds upozorava kako nije uputno koristiti "feudalno-vazalni rječnik" za opisivanje takvih prigoda u kojima je riječ o dužnostima i položajima u "državnom" aparatu (S. Reynolds, Fiefs..., str. 404-405). Tvrtkov čin valja svakako smještati u takav kontekst, kako se razabire iz načina na koji je car i kralj svoje dubrovačke podanike izvijestio o tomu što je bosanski kralj učinio za vrijeme svoga boravka na njegovu dvoru "zadao je vjeru (i obećao) dužnu poslušnost carskome veličanstvu" (izričaj facta fidelitate et obediencia debita imperiali maiestati vestre nalazi se u pismu što su ga dubrovačke vlasti uputile Sigismundu 7. svibnja - J. GelCiCH - L. Thallóczy (prir.), Diplomatarium relationum..., str. 391, br. 240 - te vrlo vjerojatno i doslovno reproducira iskaz iz originalnoga pisma). 
prvoga carskog i kraljevskog unučeta. Nakon što su, po rođenju i brzoj smrti (dijete je živjelo samo tri sata) carskoga i kraljevskog unučeta, pribivali svečanostima Fašnika u Beču Sigismund i Tvrtko su se vratili u Požun, pa je i tamo bosanski kralj bio počašćen sudjelovanjem u Sigismundovim političkim konzultacijama i pregovorima a za njegova boravka car i kralj je i formalno objavio dva važna dekreta - tzv. Decretum maius, kojim su regulirane sudbene i administrativne procedure, te posebni dekret o uređenju obrambenoga sustava na granici prema Češkoj i Moravskoj. ${ }^{127}$ Tek kada je sve to bilo obavljeno, Sigismund je Tvrtka II. "otpravio kući" (ad propria duximus remittendum), što također podrazumijeva formalizirani postupak "otpuštanja" a ne samovoljnu odluku.

Slijed je svih tih ritualnih čina zapravo jednostavan i lako čitljiv - "vjernost" je kralj Tvrtko II. iskazao sudjelujući u ratnome naporu i sukobu s Turcima (od ljeta 1434. godine), potom je iskazao homagium "podaništva" dolaskom (početak 1435. godine) u pratnji kovinskoga župana u Požun i po- bliže nepoznatim činom (homagium) koji se odigrao u nazočnosti dvorjanika i (kako će se vidjeti nemaloga broja) gostiju, a za sve je bio nagrađen carskom i kraljevskom "milošću" (gracia). Taj čin "milosti" bio je poziv da sudjeluje u Sigismundovoj pratnji i pribiva svečanostima tijekom kojih je dio štovanja namijenjenoga caru i kralju prenesen i na njega, pa su tako dva vladara u Beču "pod skupim, zlatom izvezenim baldahinom, posebno izrađenim za ovu priliku o trošku građana, zajedno odjahali do crkve sv. Stjepana". ${ }^{128} \mathrm{~K}$ tomu su tijekom tih zbivanja u raznim prigodama kolali darovi - računi bečke općine pokazuju da su Sigismund, Tvrtko II. i Sigismundov tast Herman II. dobili od tamošnjih gospođa posebno izrađene kopče, a jedna srebrna plitica s ugraviranim imenom Sigismundova češkoga kancelara Gašpara Schlika pojavila se čitavih šezdeset godina kasnije u inventaru stanovitoga splitskog građanina, kamo je valjda prispjela iz ostavštine nekoga od clanova Tvrtkove pratnje. ${ }^{129}$ Sve su to, pak, bili elementi koji su konstituirali "kompleksnu arenu gesti i ritualnih

127 Dekreti su formalno objavljeni 8. (Decretum maius) i 12. ožujka (dekret o organizaciji obrane granice) 1435. Vidi: Franciscus Döry et al. (prir.), Decreta Regni Hungariae 1301-1457, Akadémiai Kiadó, Budapest, 1976., str. 258-276 i 277-282. Je li objavljivanje dekreta u pisanoj formi bilo propraćeno kakvim formalnim činom, i ako jest kako je on izgledao te je li u njemu bilo mjesta i za bosanskoga kralja, ostaje zasad nepoznanica.

128 E. O. Filipović, "Boravak bosanskog kralja...", str. 235.

129 Za darovane kopče vidi: Isto, str. 236. Stavku iz splitskoga inventara napravljenog 1494. godine svojedobno je objavio Marko Šunjić, a prenosi ju E. O. Filipović (Isto, str. 233, bilj. 19) povezujući to upravo s ovim posjetom s obzirom na to da je Gašpar Schlick pisao isprave na češkome jeziku u kojima se spominje boravak bosanskoga kralja na Sigismundovu dvoru početkom 1435. godine. Ukoliko je pretpostavka ispravna, svakako se nije radilo o tomu da je pliticu "uvaženi kancelar Kaspar Schlick (1396-1449) dobio upravo tom prilikom", jer je teško i zamisliti kako bi ona iz njegovih ruku dospjela u Split; u svakome slučaju Gašpar Schlick je bio naručitelj i osoba koja darivala pliticu, a tko ju je iz pratnje bosanskoga kralja dobio ostaje do daljnjega zagonetka. 
čina" čije je značenje danas teško razaznati i čitati, velikim dijelom i zbog šturih i nejasnih opisa. ${ }^{130}$ Jedino što se čini nešto razgovjetnijim jest spoznaja da se kroza sve to reprezentiralo i reproduciralo upravo "slike u glavama" o odnosima ugarsko-hrvatskoga i bosanskoga kralja, odnosima koji su imali jasno iskazanu hijerarhijsku dimenziju u strukturi dinastičke (nad) države, pri čemu je bosanski vladar zauzimao precizno definiranu podređenu poziciju.

Osim ritualnih čina i svečanosti, međutim, Tvrtkov je posjet Požunu i Beču svakako imao i drugu dimenziju, onu praktičnih političkih dogovora i planova, koji su trebali biti praktična eksplikacija istih ovih ideja. Prvi je zabilježeni signal postojanja tih planova upravo ono ranije spomenuto pismo Matka Talovca svome kaštelanu Kalnika, Petru Horvatu. Tim pismom nalaže Matko Petru da predstavnika zagrebačkoga kaptola, donositelja pisma, odmah uvede u posjed palače, koja je bila vezana uz utvrdu, i njezinih pripadnosti. U pismu se inače objašnjava kako je Matko, kad je prošloga ljeta, 1434. godine, krenuo po kraljevskome nalogu u pohod na Bosnu svoju suprugu ostavio upravo u Kalniku, posve izvjesno u spomenutoj palači, a Petru je tada naredio da ljude zagrebačkoga kaptola, koji je kao institucija polagao prava na nju, privremeno udalje odatle. Matko u pismu naglašava privremenost takve odluke i objašnjava da njome nije prejudicirao ništa glede prava zagrebačkoga kaptola, kojemu su ona sad očigledno bila priznata. Ostavljajući ipak po strani sve implikacije okolnosti pod kojima je Matko smjestio obitelj u Veliki Kalnik (očito kao gubernator zagrebačke biskupije), ${ }^{131}$ valja ukazati na jasno iskazanu privremenu narav

130 Ovdje se oslanjam na razlaganja predočena u: Gerd Althoff, "(Royal) Favor: A Central Concept in Early Medieval Hierarchical Relations", u: Bernhard Jussen - PAmela Selwyn (ur.), Ordering Medieval Society: Perspectives on Intellectual and Practical Modes of Shaping Social Relations, University of Pennsylvania Press, Philadelphia, 2001., odakle potječe i ovaj izričaj (str. 245).

131 O fizičkim ostatcima Velikoga Kalnika vidi: Gjuro Szabo, Sredovječni gradovi u Hrvatskoj i Slavoniji, Matica hrvatska, Zagreb, 1920., str. 94-97; LaNA OKroša RožIĆ, "Arheološka istraživanja na starom gradu Veliki Kalnik u 2005. i 2006. godini", u: Cris, IX./1, Križevci, 2007. Veliki Kalnik bio je u posjedu zagrebačkoga biskupa, odnosno biskupije, u vrijeme biskupa Ivana Albena, nakon čije je smrti biskupska stolica ostala upražnjena a kao gubernator se pojavio upravo Matko Talovac (što objašnjava smještanje obitelji tamo). No, iako je Matko svome kaštelanu dao nalog za uvođenje predstavnika kaptola u posjed njihovih prava 19. ožujka 1435., ipak je daljnja sudbina Velikoga Kalnika (kao i ona susjedne utvrde Mali Kalnik) još neko vrijeme bila vezana na neki način uz Bosnu. Naime, poslije Matka kao posjednik tih utvrda pojavljuje se bosanski kralj Tvrtko II. i to kao onaj tko ih formalno drži "pod zalogom" za stanovitu sumu pozajmljenu kralju Sigismundu. Vidi o tomu: PÁl Engel, "Neki problemi bosansko-ugarskih odnosa", u: Zbornik Odsjeka za povijesne znanosti Zavoda za povijesne $i$ društvene znanosti Hrvatske akademije znanosti i umjetnosti, 16, Zagreb, 1998., str. 61. Stvarni parametri odnosa nisu, međutim, jasno vidljivi kroza sačuvana vrela, a vrijedi također primijetiti kako je krajem 14. i početkom 15. stoljeća Kalnik bio u posjedu Hrvoja i Vuka Vukčića. Teško je povjerovati da su sve ovo slučajna podudaranja, pa se "iza" sačuvanih vrela dade naslutiti složeniji, no teško razgovijetni sklop odnosa. 
toga rješenja. To, pak, stoji u uskoj vezi s činjenicom da Talovci (a riječ je zapravo o četiri brata ${ }^{132}$ ), unatoč svim zaslugama za kralja Sigismunda i vjerojatno velikim stvarnim sredstvima koja su stekli služeći mu, još uvijek nisu imali posjedovnu bazu kakvu su imali drugi Sigismundovi velikaši s dubljim plemićkim korijenima i golemim vlastelinstvima koja su osiguravala lokalnu moć (poput Gorjanskih, Celjskih, Frankopana ili Nelipčića, da ostanemo samo u južnim dijelovima Archiregnuma). ${ }^{133}$ Vraćanje kalničke palače zagrebačkome kaptolu upravo u tome kontekstu smatram signalom da je Matko u ožujku 1435. imao na obzoru rješenje toga problema, i to rješenje koje je bilo izravno vezano uz planove koji su zacrtani, ako ne i posve elaborirani, za vrijeme Tvrtkova boravka u Požunu i Beču.

Nedugo, naime, nakon upućivanja ovoga naloga kaštelanu Kalnika krenule su iz političkoga središta, carskoga i kraljevskoga dvora, poruke koje su, dakako u interpretaciji koja uzima u obzir i kasnija zbivanja, ocrtavale široki okvir tih planova. Najranija takva poruka, među onima sačuvanim i poznatim, jest ona iz Sigismundova pisma upućenog u Dubrovnik 31. ožujka, koje na žalost samo nije sačuvano ali na čiji se sadržaj dubrovačke vlasti referiraju u odgovoru sastavljenom tek 7. svibnja (komunikacija u ovo doba, čak i s carskim i kraljevskim dvorom, nije uvijek bila promptna). Sukladno, dakle, informaciji koja se otuda može razabrati, osnovicu cijeloga plana predstavljala je činjenica da se Sigismundu ukazala mogućnost preuzeti punu kontrolu nad starim Humskim Kneštvom, koje je dotad stajalo pod vrhovnom vlašću bosanskoga kralja i velikim dijelom bilo uklopljeno u "državu" Sandalja Hranića. Naime, Sigismund je u pismu od 31. ožujka tražio od Dubrovčana da budu na pomoći "humskim barunima", nekad "vjernim podanicima krune", koji su se nakon Sandaljeve smrti "vratili u uobičajenu vjernost kruni". ${ }^{134}$ Cijela je stvar, dakle, u pismu od 31. ožujka predstavljena kao već gotovo posao - Sandalj je umro, a "baruni" su se vratili pod okrilje i u vjernost kruni, no takav opis stvarnosti može samo na prvi pogled izgledati neproblematičan. Naime, Sandalj

132 O Talovcima vidi vrijednu raspravu: Elemér MÁlyusz, "The Four Tallóci Brothers", u: Questiones medii aevi novae, 3, Warsaw, 1998., s neobičnom idejom autora da braću, iako podrijetlom s otoka koji je u to doba integralni dio Ugarsko-Hrvatskoga Kraljevstva, pa time i podanike ugarsko-hrvatskoga kralja, ipak tretira kao "strance"! Riječ je dakako o tomu da su oni "etnički stranci" i to po današnjim mjerilima, što otkriva u podlozi istu misaonu matricu kakva je zamijećena kod E. O. Filipovića.

133 Matko je zapravo prvi posjed dobio tek negdje 1431. godine, prije no što je krenuo u Italiju u Sigismundovoj pratnji. Riječ je bila o posjedu Tallouch u virovitičkoj županiji (E. Mályusz, "The Four Tallóci...", str. 147). Posjed, o kojemu se i inače ne zna gotovo ništa, očito je bio takav da tamo nije mogao ostaviti ženu kad je krenuo u Bosnu u ljeto 1434.

134 Sadržaj ranijega Sigismundova pisma prepričan je ovako: Altera (littera facta Posonii ultimo marcii - op. M.A.) nos fideles eiusdem hortatur ad subsidia exhibenda baronibus terre de Chomlian olim fidelibus corone sue, qui, extincto voivoda Sandagl, ad obedienciam solitam corone eiusdem redierunt. J. GelCiCH - L. Thallóczy (prir.), Diplomatarium relationum..., str. 391, br. 240 . 
je umro 15. ožujka, pa ni uz najbolju volju nije moguće zamisliti da su se u međuvremenu, u nekih petnaestak dana, "baruni" Humske zemlje našli, sporazumjeli oko svoje budućnosti i onda o tomu izvijestili cara i kralja u Požunu. K tomu i tvrdnja da je to vraćanje u "vjernost kruni" omogućeno tek Sandaljevom smrću isto se tako pokazuje vrlo problematičnom. Još od vremena onoga pohoda Matka Talovca u Bosnu u ljeto 1434. Sandalj po svemu sudeći nije kontrolirao veći dio Humske zemlje, odnosno barem onaj dio na zapad od Neretve. Usporedo, naime, s Matkovim napredovanjem dolinom rijeke Bosne tekao je i sukob na zapadnim granicama Sandaljeve oblasti, gdje je napredovao i svoga suparnika potiskivao drugi velikaš Bosanskoga Kraljevstva, nećak i stvarni nasljednik hercega Hrvoja Vukčića Hrvatinića, Juraj Vojsalić. Njegova je intervencija omogućila humskoj vlasteli Vlatkovićima, jedinima koji su u tim krajevima doista mogli reflektirati na status "baruna", da se "otresu" Sandaljeva "patronata", doduše po cijenu prihvaćanja Jurjeva "patronata". 135
Formulacija, dakle, iz Sigismundova pisma Dubrovčanima očito ne odgovara stvarnome tijeku zbivanja, pa se može postaviti teza da ona nastoji uklopiti političko pregovaranje i krojenje planova iz vremena Tvrtkova boravka u Požunu i Beču u postojeći fond "slika u glavama" - Humsko Knešto (latinski izričaj terra de Chulmia i mađarski Halomfelde izravni su prijevodi hrvatskoga "Humska zemlja") kako ga koristi autor Sigismundova pisma jedna je od takvih slika: na dvoru se ugarsko-hrvatskoga kralja doista dobro znalo da je Humska zemlja "nekad" (u doba vladavine kralja Ludovika) bila dio dalmatinsko-hrvatske kraljevine pod upravom hrvatskoga bana, ${ }^{136}$ kao što se i u samome Humu to također dobro znalo. ${ }^{137}$ Nije u tim okolnostima teško naslutiti da je netko doista na Sigismundovu dvoru pokušavao izazvati kraljevsku intervenciju pozivajući se upravo na to staro stanje i na navodnu volju "baruna". Pri tomu se može ići korak dalje i ustvrditi da su to mogli biti samo vlastela Vlatkovići, koji su u takvoj priželjkivanoj intervenciji vidjeli šansu izvući se sada ispod "pa-

135 Dokumentarnu osnovicu ovakve rekonstrukcije tvori privilegij što ga je Vlatkovićima 12. kolovoza u Pod-Kreševu izdao Juraj Vojsalić, potvrđujući njihove posjede. Vidi: F. Miklosich, Monumenta Serbica, str. 377-379, br. CCCXIX. Interpretaciju kakva je ovdje predočena daje i P. Živković, Kralj Turtko II..., str. 173, a prihvaća je i J. MrgićRadoJčıć, Donji Kraji..., str. 116.

136 Vidi tekst dalje uz bilj. 176.

137 Usp. raščlambu o tome kako se takvom vrsti informacija upravo u Humu manipuliralo u nastojanjima oko stjecanja i očuvanja društvenoga položaja prema Mladen Ančıć, "Kako 'popraviti' prošlost: Konstrukcija memorije na nadgrobnim spomenicima 15. stoljeća", u: Povijesni prilozi, 34, Zagreb, 2008. U historiografiji se inače uzima kao "gotova stvar" da je bosanski kralj ponovno zauzeo onaj dio Humske zemlje (zapadno od Neretve), kojega se morao odreći 1356. godine, odmah po smrti kralja Ludovika, 1382. godine, no do toga nije došlo posve izvjesno sve do 1387. godine (usp. argumente za takav zaključak prema M. ANčić, Putanja klatna..., str. 210-212). 
tronata" Jurja Vojsalića, koji im je kao "gospodar" zamijenio Sandalja, ${ }^{138}$ a vremenska sekvenca o kojoj je ranije bilo riječi nagoni na pretpostavku da su "odluku o vraćanju u vjernost" dojavili na kraljevski dvor i prije no što je Sandalj umro (ne bi valjalo posve isključiti ni mogućnost da su Vlatkovići u cijelu akciju ušli zajedno $s$ kraljem Tvrtkom II. koji je s takvim idejama mogao doći pred Sigismunda; njegov je interes, nakon što je svoj položaj popravio intervencijom Matka Talovca, zacijelo išao za tim da smanji utjecaj velikaša, u ovome slučaju Jurja Vojsalića, i s druge strane osigura trajnu potporu Sigismunda).

No, ako su doista stvari i stajale tako te su pozivi na praktično djelovanje bili informirani "slikama u glavama" izgrađenim na starijem iskustvu, stvarni je plan izgleda bio znatno složeniji te je vjerno zrcalio pravu imperijalnu atmosferu Sigismundova dvora. U prvome redu valja upozoriti da je plan koji ocrtavaju zbivanja iz proljeća i ljeta 1435 . bio dio "velike strategije" sukoba s Turcima, jednoga od onih problema koji su bili Sigismundova trajna preokupacija, te da je njegov obzor daleko nadmašivao i Humsko Kneštvo i Bosnu. U isto vrijeme kad je od Dubrovčana tražio potporu za humske "barune", Sigismund je poslao jednoga od svojih vitezova, Fružina, a riječ je zapravo o sinu posljednjega bugarskog cara Ivana Šišmana, u Albaniju, što je bio rezultat pristizanja na dvor vijesti o uspjesima albanskih ratnika u sukobima s Turcima, poglavito o njihovoj pobjedi nad vojskom koju je početkom 1435. godine predvodio poglavar Skopskoga krajišta, Isak. ${ }^{139}$ Fružinova je misija imala zapravo tek obavještajnu narav, jer se on u Albaniji zadržao samo mjesec dana, a na povratku je prošao opet kroz Dubrovnik pa se zahvaljujući tomu zna da je vodio četvoricu albanskih poglavara, koji su očito trebali u političkome središtu,

138 O nastojanjima pripadnika vlastelinskoga roda Radivojevića-Jurjevića-Vlatkovića da steknu položaj samostalnih "gospodara" ("rusaške gospode") vidi: M. ANčić, Na rubu Zapada..., str. 74-78, pri čemu se interpretacija zbivanja iz 1435. koju ovdje predočujem unekoliko razlikuje od one koju sam ranije zastupao. Interpretaciju prema kojoj su upravo Radivojevići-Jurjevići-Vlatkovići bili ti koji su zazivali Sigismundovu intervenciju nalazi potporu u njihovu vrlo ranom pokušaju da preuzmu Sandaljev udjel u Drijevima. Takav njihov zahtjev došao je Dubrovčanima već prije 29. ožujka 1435. (vidi: Đ. Tošić, Trg Drijeva..., str. 156, bilj. 6). Temeljem toga može se čak naslutiti kako su, iz svoga skučenog lokalnog obzorja, humski vlastelini zamišljali ishod svoje akcije, no na to ću se još vratiti.

139 O pobjedi albanskih ratnika nad Isakovom vojskom Dubrovčani su detaljno izvijestili Sigismunda u pismu od 16. veljače 1435. J. Gelcich - L. Thallóczy (prir.), Diplomatarium relationum..., str. 389, br. 237. Fružina kao sina Ivana Šišmana identificira S. Ćirković, Herceg Stefan..., str. 10, a njegovo se ime javlja u pismu što ga je dubrovačka općina uputila kovinskome županu Matiji 7. svibnja (MOL DF 290437). Kratko izvješće o njegovu dolasku i boravku u Dubrovniku dio je pisma dubrovačke općine Sigismundu od 28. svibnja (MOL DF 290439), no iz toga se izvješća ne može razabrati što je bio Fružinov zadatak. Jedino je izvjesno da je taj zadatak bio protivan turskim interesima te su se zbog toga Dubrovčani bojali da spoznaje o tomu da su mu pružili pomoć ne dospiju do turskih dužnosnika. 
na dvoru, sklopiti prave i čvrste dogovore. ${ }^{140}$ Sljedeća je uporišna točka plana, kojemu epizoda s Fružinovom obavještajnom misijom daje snažne elemente sofisticiranosti, bila predviđeno preuzimanje Humskoga Kneštva od strane Matka Talovca. Osim Dubrovčana, Matku su u preuzimanju kontrole nad Kneštvom, sudeći barem prema pisanim tragovima, trebali pomoći hrvatski banovi, Ivan i Stjepan Frankopani, kojima je kralj u tome smislu izdao pisani nalog 26. travnja 1435..$^{141}$ Kraljevska je kancelarija u ovome pismu stvari predstavljala bitno drugačije no u onome pismu upućenom mjesec dana ranije u Dubrovnik. Dok je tamo bilo riječi o već donesenoj odluci "baruna", ovdje se govori o tomu da "svi plemići, stanovnici i oni koji tamo žive" iskazuju spremnost (offerunt se redituros) za ponovno podčinjavanje ugarskoj kruni. Iz toga proizlazi kraljevo traženje da banovi u njegovo ime okupiraju Humsku zemlju (volumus ipsam terram Homlyan per vestras fidelitates nomine nostre maiestatis occupari), pri čemu trebaju tražiti i očekivati pomoć bosanskoga kralja, Jurja Vojsalića, Ivaniša Nelipčića (autor pisma očito nije znao, ili je samo zaboravio da je ovaj umro nekoliko mjeseci ranije) i krbavskih knezova te plemića i Vlaha kraljevine Hrvatske (cum subsidiis et auxiliis fidelium nostrorum illustris regis Bosne, et magnificorum Georgii filii Woyzali et Johannis filii Iwan comitis Cetine, comitum Corbavie ac nobilium et walahorum dicti regni nostri Croatie). Razlike vjerojatno treba pripisati tomu da su tekstove diktirale različite osobe, no svakako valja primijetiti da je ovaj cirkularni nalog (vjerojatno je vrlo sličan nalog otišao i na adrese svih u pismu spomenutih, ${ }^{142}$ možda čak i već odavno mrtvome Ivanišu Nelipčiću), bio upravljen dobrim dijelom osobama čiji se boravak u Požunu (ako ne i u Beču) preklapao s onim kralja Tvrtka II.

Naime, dvadesetak dana prije naloga banovima Ivanu i Stjepanu, kraljevska je kancelarija uputila nalog zagrebačkome kaptolu za provođenje presude u teškome prijeporu koji se vodio u najužem krugu Sigismundovih velikaša Ugarsko-Hrvatskoga

140 Dubrovačka vrela koja govore o Fružinovu povratku sabrala je DušAnKa Dinić-KNEŽEvić, Dubrovnik i Ugarska u srednjem veku, Novi Sad, 1986., str. 100.

141 Taj je nalog tiskan u Lajos Thallóczy - Samu Barabás (prir.), Codex diplomaticus comitum de Frangepanibus, I. (dalje: Codex comitum), MTA, Budapest, 1910., str. 265266, br. CCLXXII.

$142 \mathrm{U}$ pismu se to i izrijekom veli jer se nabrajanje onih koji trebaju sudjelovati nastavlja riječima quibus scripta nostra superinde direximus. Ovaj cirkularni nalog stavlja pod drugačije svjetlo i vremenski slijed postupaka već spominjanoga Jurja Vojsalića, koji je izazvao nesporazume u historiografiji. Naime, Dubrovčani su 6. travnja 1435. namjeravali pisati Jurju i preporučiti mu svoje carinike u Drijevima (Đ. Tošść, Trg Drijeva..., str. 156, bilj. 7) što se povezivalo s činjenicom da je sredinom svibnja doista uslijedila Jurjeva vojna intervencija u Drijevima (S. ĆIrković, Herceg Stefan..., str. 9, bilj. 12, s citiranim odlukama dubrovačkoga Vijeća umoljenih od 16. svibnja, iz kojih se vidi da je Juraj u Drijeva poslao svoje ljude na barkama, koje je onda zaplijenilo tamo stacionirano dubrovačko brodovlje). No, pretpostavi li se da je Juraj bio u pratnji kralja Tvrtka II. za njegova posjeta Požunu i Beču i da se početkom travnja vratio na svoje posjede (a očito ih je imao i negdje na jadranskoj obali, jer je raspolagao barkama) te odatle "pustio glas" o predstojećim promjenama u Humu i Drijevima, stvari izgledaju posve drugačije. U 
Kraljevstva, i to među relativno bliskim rođacima. Riječ je o devetorici braće Frankopana, sinovima kneza Nikole, s jedne strane, i knezu Ulriku II. Celjskom, s druge strane. ${ }^{143}$ Uzrok prijepora ležao je u teškim i dramatičnim zbivanjima tijekom kojih je, kako izgleda, Ulrikov otac Fridrik II. Celjski ubio njegovu majku, Elizabetu, sestričnu Nikole, oca Ivana, Stjepana i ostale braće (dakle, kćer njegova strica Stjepana). ${ }^{144}$ Kao rezultat tih dramatičnih zbivanja Ulrik II. nikad nije uspio dobiti miraz svoje majke, golemu svotu od 32.000 dukata, pa je Sigismund za vrijeme boravka u Požunu prvih mjeseci 1435. godine morao razriješiti taj prijepor $s$ obzirom na to da su Ivan, Stjepan i ostala braća bili nasljednici Elizabetina oca. Iz teksta naloga upućenoga zagrebačkom kaptolu nije moguće niti naslutiti kad je konačna odluka u postupku donesena i koliko je on trajao, ${ }^{145}$ no ona je bila krajnje nepovoljna za hrvatske banove i njihovu braću jer je kralj presudio da su Ulriku II. dužni prepustiti golemi dio svojih nasljednih posjeda, između ostaloga i polovicu otoka Krka. No, nije to bila i jedina nepovoljna vijest koja je za Ivana i Stjepana dolazila sa Sigismundova dvora. Samo tri dana prije ispostavljanja naloga za sudjelovanje u preuzimanju Huma, 23. travnja, ispostavila je kraljevska kancelarija, i to po "izvješću" (Relatio) Matka Talovca, nalog banovima Ivanu i Stjepanu da bezodvlačno knezu Nikoli Šubiću Zrinskom vrate utvrdu Slunj sa svim pripadnostima ili isplate novac za koji je tu utvrdu svojedobno založio njihov otac Nikolinu ocu, Pavlu. ${ }^{146}$ Uzimajući ovo u obzir nije nikakvo čudo što je nalog za sudjelovanje u pohodu na Hum ostao bez ikakva odziva banova Ivana i Stjepana, ${ }^{147}$ a može se u tome smislu krenuti i korak dalje te

tome slučaju i njegova intervencija sredinom svibnja postaje razumljiva kao odziv na (cirkularni kraljevski) nalog kojega je jedan primjerak sačuvan u arhivu Frankopana.

143 Kraljevski nalog zagrebačkom kaptolu od 4. travnja 1435. u: L. Thallóczy - S. BArABÁs (prir.), Codex comitum, str. 258-263, br. CCLXX.

144 Dramatičnu pripovijest o nesretnom Elizabetinu kraju i svim zapletima koji su iz toga proizašli opširno razlaže VJeKoslav KLAIć, Krčki knezovi Frankapani, I., Matica hrvatska, Zagreb, 1901., str. 209 i d., oslanjajući se između ostaloga i na ovdje citirani kraljevski nalog.

145 Na početku naloga donošenje kraljevske presude datira se ovako: Noveritis, quod nobis tempore date presencium unacum prelatis et baronibus ac dicti regni nostri proceribus pro nonnullis regni nostri negotiis expediendis hic Posonii (L. Thallóczy - S. Barabás (prir.), Codex comitum, str. 258 - naglasio M.A.), no iz daljnjega se teksta vidi da je donošenje odluke bio dio dugotrajnijega procesa raspravljanja: diversisque inter partes utrasque per certos prelatos et barones nostros per maiestatem nostram ad id deputatos colloquiis seu interlocutionibus prehabitis. (Isto, str. 260). Naslućena duljina postupka u podlozi je tvrdnje da se boravak Tvrtka II. na Sigismundovu dvoru barem (dijelom) preklapao s boravkom hrvatskih banova i Ulrika II. u Požunu (valja ovdje podsjetiti da je Ulrikov djed, Herman II., boravio u Beču zajedno sa Sigismundom i Tvrtkom II.). Njihova nazočnost, što onda podrazumijeva i nazočnost mnogih drugih velikaša Kraljevstva, stvara drugačiju pozadinu ritualnoga homagiuma bosanskoga kralja.

146 L. Thallóczy - S. Barabás (prir.), Codex comitum, str. 264-265, br. CCLXXI.

$147 \mathrm{U}$ prosudbi reakcije banova Ivana i Stjepana valja voditi računa o tomu da je njihov društveni položaj, velikaša Kraljevstva, bio takav da su oni kraljevske odluke u prije- 
ustvrditi da je ovaj niz dokumenata iz travnja 1435 . otvorio spiralu pogoršanja odnosa banova Ivana i Stjepana s kraljevskim središtem pa slijedom te logike i s Matkom Talovcem. Pri tomu nije nevažno primijetiti kako se u nevelikom izvornom materijalu koji se odnosi na krajeve južno od Save ipak jasno raspoznaje da je u prvim mjesecima 1435., nakon što je dopratio kralja Tvrtka II. u Požun, Matko Talovac uspio uspostaviti kontrolu nad komunikacijskim kanalima koji su od dvora vodili $\mathrm{k}$ tim krajevima. Uslijed toga ne samo da su nalozi braći Ivanu i Stjepanu išli preko njega, nego je upravo on bio osoba koja je naložila kraljevskoj kancelariji 28. lipnja 1435. izdavanje kraljevskoga privilegija $s$ potvrdnicom za posjede kneza Antonija Blagajskoga. ${ }^{148}$ Braća Ivan i Stjepan očito $s$ Matkom nisu uspostavili dobre odnose $\mathrm{i}$ iz toga će se, nakon kraha planova vezanih za preuzimanje Huma, razviti puno neprijateljstvo koje će eskalirati do te mjere da će Ivan i Stjepan izgubiti svoj banski položaj te čak biti oglašeni za pobunjenike protiv kraljevske vlasti. Od kraja 1435. godine buknut će između dvije strane puni oružani sukob oko naslijeđa Ivaniša Nelipčića, s obzirom na to da je Ivan bio oženjen Katarinom, Ivanišovom kćeri te je nizom pravnih radnji, čak i uz privolu samoga Sigismunda, postao nasljednikom svoga punca. Ishod je toga sukoba odlučio tek puki slučaj, prirodna smrt Ivana Frankopana potkraj 1436. godine, i to u vrijeme i pod okolnostima koje nisu izgledale povoljno za Talovca i njegovu braću. ${ }^{149}$

Za ovdje razmatrane probleme odnosi braće Frankopan i Matka Talovca važni su na dvije razine. $\mathrm{Na}$ prvoj jer je izgleda upravo u ovo vrijeme

porima o kakvima je ovdje riječ "vagali" ne logikom utemeljenosti u običaju ili zakonu, nego logikom relacija "naklonosti" ili "nenaklonosti". Drugim riječima, to su bila "politička suđenja" u onom značenju koje koristi Hanna Vollrath, objašnjavajući da su to "suđenja koja koriste sudbena sredstva u političke svrhe" (za ovakvu definiciju vidi: Hanna Vollrath, "Rebels and Rituals: From Demonstration of Enmity to Criminal Justice", u: G. Althoff et al. (ur.) Medieval Concepts..., str. 91. Uzastopne odluke na svoju "štetu" (a na "korist" Ulrika II. Celjskog i Nikole Šubića Zrinskog) nisu mogli tumačiti drugačije no kao iskaze "nenaklonosti" i nastojanja da ih se udalji od političkoga središta. Istodobno, postojanje naloga za određene pravne radnje (uvođenje u posjed), pa čak i njihovo provođenje, nije automatizmom značilo i stvarnu promjenu - primjerice nemogućnost da se dalje ubiru prihodi posjeda i ostvaruju druge koristi od njega, o čemu se u našoj historiografiji nikad nije vodilo računa, a što je vrlo često u srednjovjekovnome društvu bilo vrelo društvenih konflikata.

148 L. Thallóczy - S. Barabás (prir.), Codex Blagay, str. 312, br. CLXVIII. Doda li se tomu da je za vrijeme svoga pohoda u Bosnu u drugoj polovici 1434. izgradio i uspješno širio takvu predodžbu o sebi da su u Dubrovniku razmišljali bi li bilo uputno tražiti od njega potvrdu ugovora kojim je gradska općina od bosanskoga vojvode Radoslava Pavlovića kupila polovicu Konavala (P. Žıvoović, Turtko II..., str. 173, bilj. 61), ne će biti teško razabrati kako je Matko raspolagao uzornom vještinom društvene komunikacije. Ne treba naime zaboraviti kako je on u ovo vrijeme još uvijek bio samo kovinski župan i beogradski kapetan, pa bi slijedeći takvu logiku bilo vrlo teško razumjeti i samu ideju traženja njegove potvrde kupoprodajnoga ugovora.

149 Stjepan Frankopan i Matko Talovac su zajedno bili u Sigismundovoj pratnji tijekom pohoda u Italiju 1432. godine (E. MÁlyusz, "The Four Tallóci...", str. 147), pa je moguće da neka vrst neslaganja, ili čak otvorenoga neprijateljstva tinja još od tada. Otvo- 
aktualizacije plana za preuzimanje Huma i u sklopu toga trga u Drijevima, došlo do približavanja i sklapanja savezništva (vjerojatno na temelju zajedničkoga suparništva s Matkom) između hrvatskih banova i Sandaljeva nasljednika te su oni čak sklopili i neku pobliže nepoznatu rodbinsku vezu. ${ }^{150} \mathrm{Na}$ drugoj razini ti su odnosi važni s pogledom na ono što će o Ivanu Frankopanu nakon njegove smrti i preuzimanja naslijeda Ivaniša Nelipčića kao njegovu "sliku" producirati Sigismund i Matko, što se razaznaje iz one ovdje već spominjane svečane potvrdnice Talovčevih posjeda izdane nekoliko mjeseci pred kraj Sigismundova života, 27. rujna 1437. Ta je darovnica začudo ostala nepoznanicom u hrvatskoj historiografiji iako je tiskana još 1907 . godine te su je srpski povjesničari relativno često koristili. $\mathrm{Za}$ ovdje predočenu raščlambu važno je uočiti da je pri naraciji Matkovih zasluga $\mathrm{u}$ tome dokumentu između ostaloga navedeno kako se nekadašnji ban Ivan odmetnuo od kraljevske vlasti te si je za saveznike uzeo turskoga sultana i vojvodu Stipana, namjeravajući se, ni više ni manje, no proglasiti hrvatskim kraljem, odnosno okruniti se za kralja kraljevina Dalmacije i Hrvatske. ${ }^{151}$ Cijela konstrukcija, s uvidom u postojeći i poznati fond vrela, čini se krajnje nevjerodostojnom (Ivan Frankopan mogao je eventualno biti optužen tek zbog ogluhe na kraljev nalog za pohod u Hum) i osmišljenom kako bi se prikrila jednostavna činjenica da je rat za naslijeđe Ivaniša Nelipčića bio pokrenut unatoč tomu što je dotadašnji hrvatski ban bio posve pravno "pokriven" kao njegov zakoniti nasljednik. U tome kontekstu optužba zbog (navodno) planirane krunidbe za hrvatskoga kralja istaknuta je kao krajnji oblik izdaje "kraljevskoga veličanstva". U projiciranoj slici kralj povjerenim zemljama vlada po "Božjoj milosti" na vrhu društvene piramide, pa je pokušaj remećenja toga poretka jednak nastojanju za promjenom "Božje volje" te je stoga naglasak u tekstu naracije tako i postavljen (contra culmen nostrum), dok

reni sukob iz 1435./36. godine temeljem tada dostupnih vrela relativno detaljno prikazao je V. Klaić, Krčki knezovi..., str. 224 i d. Danas bi ipak, s arhivskim materijalom različite provenijencije, bilo moguće puno više reći o tim zbivanjima, između ostaloga i o Talovčevim neuspjesima.

150 Usp. S. Ćirković, Herceg Stefan..., str. 21 i d.

151 Odnosni dio teksta glasi: Tandemque perfidissimum Omorat Turcorum dominum, necnon Stephanum nepotem ..... [cete]rosque quamplurimos nostros et regni nostri emulos in suam amicitiam et favorem acquirendo, plurimos nobiles et alterius status dictorum regnorum nostrorum Dalmatie et (Croatie - op. M.A.) ..... nil aliud intendens nisi ut se contra culmen nostrum regium in ipsis regnis nostris in regem coronari facere potuisset - L. Thallóczy - A. Áldásy (prir.), Codex diplomaticus partium..., str. 117. Vrijedi tek pripomenuti kako S. Ćirković koristi ovaj tekst i uzima iz njega informacije pri razmatranju uloge vojvode Stipana u sukobu Frankopana i Talovca (S. Ćrrković, Herceg Stefan..., str. 22), izbjegavajući spomenuti optužbu o krunidbi za hrvatskoga kralja. Kod toga valja znati da su upravo ovakvi elementi povijesne naracije u ondašnjoj društvenoj atmosferi bivše Jugoslavije imali ključno značenje u učvršćivanju i reprodukciji nacionalnih identiteta, pa ovaj primjer zorno ilustrira razinu surevnjivosti nacionalnih historiografija ali i način na koji su svoj "društveni zadatak" shvaćali i razumijevali profesionalni povjesničari. 
protubožansku narav pobune samo potvrđuje savezništvo $s$ turskim sultanom, ovjerenim "neprijateljem Krista i križa". Sličnu ulogu ima i vojvoda Stipan, no, a to valja posebice naglasiti, svečana je darovnica Matku izdana upravo $\mathrm{u}$ vrijeme kada se $s$ tim istim vojvodom Stipanom pregovaralo o "izmirenju", možda čak i u vrijeme kada je dogovor bio postignut te je Sandaljev nasljednik već dobio i odgovarajući kraljevski privilegij. ${ }^{152}$ Tu prividnu (iz naše današnje perspektive) nesklapnost, međutim, razrješuje sam svečani privilegij Talovcu. Iz njegova se daljega teksta vidi kako čak i ovakvi "akti izdaje" iz kojih je proizlazio i fizički, odnosno vojni sukob, i koji se opisuju kao ono "za što bi dostoino plemenitim' ludem' glave od'sići i nih' plemen'štine uzeti", 153 nisu konstituirali konačni kraj odnosa vladara i njegova podanika. Naime, u završnome se dijelu naracije o Matkovim uspjesima pojavljuje misao, izrečena u prvome licu kraljevskoga plurala, prema kojoj su vojni uspjesi kraljevskoga povjerenika tako "ukrotili razuzdanost" Ivana Frankopana da bi ovaj, samo da ga u tome nije spriječila smrt, "morao, htio ne htio, doći i osobno moliti milost našega veličanstva". ${ }^{154}$ Traženje i davanje kraljevske (ili čak carske) milosti nakon (neuspješnih) akata izdaje dakle rekonstituiralo je pokidano društve- no tkivo te je kao slijed čina imalo sve značajke rituala koji su "maskirali" društvene procese pregovaranja i pogađanja. Cak i onda kada su konflikti izazvani tim procesom eskalirali do otvorene uporabe nasilja, u njihovu se saniranju nastojalo održati sliku beskonfliktnoga društva kao beskrajno važan element u održanju ukupne socijalne konstrukcije.

Takav jedan proces društvenoga pregovaranja i pogađanja bio je i pokušaj preuzimanja Humskoga Kneštva, ili još preciznije onoga što su neki akteri još uvijek tako doživljavali. O tomu, kao potpunome neuspjehu, nema dakako ni riječi u svečanome privilegiju za Matka Talovca, gdje naracija s ritualnoga dovođenja kralja Tvrtka II. u Požun neosjetno "preskače" na sukob s Ivanom Frankopanom. No, u tome se segmentu naracije vojvodi Stipanu pridaje izrazito negativna uloga te ga se, kako je rečeno, povezuje s turskim sultanom, čime se pripovijest zapravo neizravno referira na humski neuspjeh. No, prije nego što pretresem tu tursku ulogu u cijelome sklopu zbivanja, valja se vratiti na zbivanja iz svibnja 1435. Iako su se tada banovi Ivan i Stjepan Frankopani oglušili na kraljevski nalog za poduzimanje pohoda i preuzimanje "Humske zemlje", čini se da je i ono što je poduzeo Juraj Vojsalić bilo dovoljno za neku vrst opće-

152 S. Ćirković, Herceg Stefan..., str. 22, bilj. 7, citira jedan znatno kasniji dokument iz kojega se vidi da je vojvoda Stjepan doista imao Sigismundov privilegij te njegov nastanak datira između lipnja i (8.) prosinca, kada je Sigismund umro.

153 Izričaj potiče iz ovdje već citirane potvrdnice posjeda braće Vlatkovića i Vuka Vukičevića što ju je 12. kolovoza 1434. izdao Juraj Vojsalić. F. MikLosich, Monumenta Serbica..., str. 377, br. CCCXX.

154 L. Thallóczy - A. Áldásy (prir.), Codex diplomaticus partium..., str. 118: sicque eius ferocitatem edomavit, ut idem comes Johannes nisi morte preventus fuisset, temporali personaliter ad inquirendam nostre maiestatis gratiam, velit, nolit, venire debuisset. 
ga priznavanja Sigismundova kraljevskog autoriteta, odnosno vlasti nad tim područjem. Sve do toga trenutka konačni cilj, predaja Humskoga Kneštva u vlasništvo Matku Talovcu, nikad nije bio ekspliciran, mada se može prilično uvjerljivo tvrditi da to i nije bila potpuna nepoznanica. Najuvjerljiviji argument $\mathrm{u}$ prilog toj tvrdnji predstavljaju razlike u pismima što ih je dubrovačka općina uputila caru i kralju Sigismundu te "kovinskome županu" Matku Talovcu 7. i 28. svibnja 1435. Upućivanje para pisama kralju i Matku uvela je općina u praksu još početkom 30-ih godina, ali je to postalo pravilo upravo nakon onoga posjeta Tvrtka II. Požunu i Beču. Obično su se ta pisma sadržajno vrlo malo razlikovala, no pisma od 7. i 28. svibnja ipak imaju jednu važnu razliku - u oba slučaja u pismu upućenome Sigismundu preporučuje se Sandaljeva nasljednika, vojvodu Stipana, ${ }^{155}$ dočim te i takve preporuke nema u pismima Matku Talovcu.

Uglavnom, tek je potpuno preuzimanje Humske zemlje (ili barem onoga dijela na zapad od Neretve) stvorilo uvjete u kojima je konačni dio plana mogao biti obznanjen, pa je to, doduše ne zna se u kojoj prigodi i kada, car i kralj doista i učinio. Prvo je ob- znanio da je s preuzimanjem zemlje preuzeo i solnu komoru, odnosno da ona odsad pripada njemu, a potom je Humsku zemlju, sad očito kao Humsko Kneštvo, posebnom ispravom ( $p a-$ tentes litteras) predao na "upravljanje i vladanje" (gubernationem et regimen) Matku kojemu je onda (kao regalia) pripadalo i pravo ubiranja prihoda od soli na drijevskom trgu, što ga je za života uživao Sandalj. ${ }^{156}$ Cjeloviti plan koji se otkriva tek s ovim pojedinostima doista je bio dostojan imperijalnoga središta kakvo je nastojao izgraditi Sigismund i počivao je $s$ jedne strane na iskustvu što ga je Matko Talovac stekao kao kovinski župan i beogradski kapetan organizirajući obranu od Turaka na savsko-dunavskoj crti, ${ }^{157}$ a s druge strane na sposobnosti dvodimenzionalne vizualizacije prostora $\mathrm{u}$ formi koliko-toliko realističnoga zemljovida. Dobivši Humsko Kneštvo i solni trg u Drijevima, s relativno velikim prihodima, mogao je Matko organizirati dovoljnu vojnu silu na sjeverozapadnoj bojišnici spram Turaka te preko Korčule i Dubrovnika još i pomagati Albance, koji su pokazali da se mogu nositi sa snagama skopskoga zapovjednika Isaka. To je bilo tim lakše što uvjeti ratovanja na ovoj strani, isključivo u planinskim predjelima, nisu bili ni izbliza takvi

155 Vidi tekst pisma od 7. svibnja kralju Sigismundu prema J. Gelcich - L. Thallóczy (prir.), Diplomatarium relationum..., str. 392, br. 240, a onoga od 28. svibnja prema MOL DF 290439, gdje je u kraćoj formi ponovljen dio informacija iz pisma od 7. svibnja.

156 Parafrazu Sigismundova pisma o tomu kako pravo na prihod s Drijeva poslije Sandaljeve smrti prelazi na kralja vidi prema dubrovačkome pismu od 25. srpnja 1435. u Đ. Tošić, Trg Drijeva..., str. 156, bilj. 9. Opis cijeloga postupka predaje Huma, u smislu Humskoga Kneštva, Matku Talovcu, koji je uslijedio nakon toga, najjasnije je prikazan u pismu što ga je dubrovačka općina uputila ovome izvješćujući ga o neuspjehu postupka 31. kolovoza iste godine - vidi ovdje Prilog II.

157 Usp. detaljni prikaz te organizacije prema E. MÁLyusz, "The Four Tallóci...", str. 144-146. 
kakvi su bili u savsko-dunavskoj ravnici, gdje se moglo očekivati doista velike neprijateljske snage. Plan je, međutim, išao i korak dalje jer je u međuvremenu Matko dobio i bansku čast u kraljevini Slovinju (banatus regni Sclavonie) ${ }^{158}$ te je tako mogao ostvariti dotad teško zamislivu koncentraciju resursa koji su mu, očito prema takvoj zamisli, omogućavali i punu kontrolu nad Bosanskim Kraljevstvom, u kojem je i nadalje zadržao neke utvrde (moguće je čak i da je predaja Velikoga i Maloga Kalnika Tvrtku II., o čemu je ranije bilo riječi, bila neka vrst nadoknade za utvrde koje je zadržao Matko).

No, cijeli se plan sredinom kolovoza 1435. srušio kao "kula od karata" kad se u blizini Drijeva, kamo je došao Matkov izaslanik kako bi preuzeo trg, pojavio odred od 1500 Turaka - Matkov je izaslanik, stanoviti Juraj Cher, pobjegao iz Huma "glavom bez obzira" i to takvom brzinom da su Dubrovčani ironično pisali i Sigismundu i Matku da ga nisu mogli sustići ni njihovo pismo, koje su mu uputili, ni poklisar koji je osobno $s$ njim trebao stupiti u dodir. Razlozi raspada na prvi pogled dobro osmišljene i nekoliko mjeseci građene konstrukcije moraju se, po mome sudu, tražiti u razlikama "slika u glavama" koje su informirale djelovanje svih sudionika. Pokretanje akcije u Humu s idejom "povratka u vjernost ugarskoj kruni", zamisao, kako je već rečeno, najvjerojatnije RadivojevićaVlatkovića, polazilo je od toga da će autorima zamisli "zahvalnost" kralja, kome su "vratili" njegova "prava nad zemljom", omogućiti preuzimanje Sandaljeva udjela u Drijevima. Kada su vidjeli da od toga nema ništa, humska se vlastela po svemu sudeći "ohladila" u odnosu na ono što su sami započeli, pa se iz dubrovačkoga objašnjenja Cherova neuspjeha razabire kako su se njihovi predstavnici u Drijevima prilično neprijateljski ponašali spram Matkova izaslanika. ${ }^{159}$ $S$ druge strane, Sigismund i Matko su polazili od vlastitih "slika u glavama" o tomu kako je uređeno ubiranje prihoda od soli kroz "solne komore", ne vodeći računa o tomu da to u Bosanskome Kraljevstvu nisu više bila klasična regalia. U tome je smislu znakovita uporaba pojma "kraljevski prihodi koji proizlaze iz gospodstva nad Humskom zemljom" (terre $\mathrm{Ha}$ lomfelde prouentuum regabilium sibi racione dominii prouenientium), a što je po takvu tumačenju podrazumijevalo prihode od solnoga trga u Drijevima, kako su to očito zamišljali Sigismund i Matko. No, solni je trg u Drijevima već odavno prestao biti regalia "humskoga gospodina", odnosno bosanskoga kralja kao neke vrsti nasljednika te pozicije, na isti način na koji su tradicije političke zasebnosti Humskoga Kneštva, klasične "zemlje" kopnile pod vlašću bosanskih vladara (kako je to vidljivo u vernakularnome imenu contrate, kako se to područje najčešće nazivalo administrativnim nazivom u 15. stoljeću). I ne samo to - čak je i bosanski kralj početkom 20-ih godina 15 . stoljeća izgubio pravo na ubiranje prihoda od

$158 \mathrm{Na}$ tome mu Dubrovčani čestitaju u pismu od 30. kolovoza 1435. J. Gelcich - L. Thallóczy (prir.), Diplomatarium relationum..., str. 394, br. 242.

159 Vidi tekst u: Đ. Tošıć, Trg Drijeva..., str. 156, bilj. 11. 
trgovine solju, pa se taj prihod kad se situacija konačno kristalizirala dijelio na tri djela - polovicu je dobivao bosanski veliki vojvoda Sandalj Hranić Kosača, a po četvrtinu prihoda ubirali su vojvoda Radoslav Pavlović, odnosno pripadnici šire rodbinske zajednice Radivojevića-Vlatkovića. ${ }^{160}$ Upravo u tome kontekstu valja tumačiti i objašnjenje koje Dubrovčani daju Matku, a prema kojemu Drijeva nisu oppidum već burgum, što zapravo opet zrcali razlike u "slikama u glavama". U oppidumu se vlast preuzima jednostavno pojavom zastupnika, u burgumu treba pokazati spremnost na nasilje, ako već ne treba doista i primijeniti to nasilje.

$\mathrm{Uz}$ to valja svakako primijetiti još jednu važnu stvar. Slika o "protuturskim ratovima" kakva je izgrađena u političkom središtu ${ }^{161}$ nije posvuda bila prihvaćena $\mathrm{u}$ istome obliku. $\mathrm{Na}$ razlici u toj slici gradila se (poglavito) i reakcija Dubrovčana na Sigismundove planove. Jasno je to iskazano već i u načinu na koji su postupali s njegovim izaslanikom Fružinom, nastojeći svoje usluge u toj misiji prikriti u što je moguće većoj mjeri. Neizgovorena no svakako (pre)važna spoznaja u ovoj situaciji bila je to da je područje na kojem su dubrovački trgovci (a trgovinu Dubrovčani uvijek ističu kao temelj svoje egzistencije) operirali i razgranali svoje poslovanje već uvelike bilo pod većom ili manjom kontrolom Turaka. U takvim okolnostima, kada je njihova egzistencija doista u dobroj mjeri ovisila o toleranciji lokalnih turskih zapovjednika, sama zamisao da njihov grad postane jedno od središta protuturskoga ratnog napora (a to je bilo neizbježno ukoliko bi se ostvarili planovi vezani za Albaniju) morala je biti neke vrsti "noćne more". Prikrivena nekooperativnost Dubrovčana koja je iz svega ovoga proizlazila, "pokrivena" stvarnim i izmišljenim objašnjenjima, ${ }^{162}$ svakako je jedan od važnih razloga za propast planova napravljenih u politič-

160 Sandalj Hranić postao je važan čimbenik uređenja prilika u Drijevima još 1404. godine (E. Kurtović, Veliki vojvoda..., str. 135), ali se kod zakupa prihoda od trga pojavljivao i kralj sve do početka 20-ih godina 15. stoljeća (Đ. Tošıć, Trg Drijeva..., str. 126-127), od kada se može pratiti naznačeni sustav podjele prihoda. Okolnosti i tempo ovih promjena nisu u historiografiji dobili dostatna objašnjenja (usp. E. KuRTović, Veliki vojvoda..., str. 347-351), pa to ostaje otvoreni problem.

161 Za evoluciju Sigismundova shvaćanja važnosti turskoga čimbenika, u što se ovdje rekonstruirani plan za izgradnju sustava obrane na zapadnome boku izvrsno uklapa, vidi: János M. BaK, "Sigismund and the Ottoman Advance", u: Isti, Studying Medieval Rulers..., str. 1 i d.

162 Kada su "vojvodu Stipana" preporučivali u svibnju Sigismundu pozivali su se Dubrovčani na njegovu izrazitu naklonost spram njihovih trgovaca (vidi ovdje bilj. 153), no u pismu Matku Talovcu stvari su predstavljali na posve oprječan način te isticali vojvodinu spremnost da im pričini velike štete, pozivajući se pri tome i na "opće znanje" o tomu "kakvi su ljudi Bošnjani", prevrtljivi i sumnjičavi (vidi: Prilog II.). No, tome su "sumnjičavom vojvodi Stipanu" ipak dojavljivali što kralj i Matko namjeravaju uraditi s drijevskim prihodom (Đ. Tošić, Trg Drijeva..., str. 157, bilj. 13). U pismu Matku Dubrovčani se pozivaju na ugovor koji su sklopili s (tada već pokojnim) Sandaljem, a koji je stupio na snagu 1. travnja 1435., no u stvarnosti je ugovor odmah po vijesti o Sandaljevoj smrti storniran te nije stupio na snagu sve do listopada iste godine, kada su ga obje strane potvrdile (S. Cirković, Herceg Stefan..., str. 14-15). Posebno bi se 
kome "središtu", a koliko su toga bili svjesni Sigismund i Matko Talovac posve je drugo pitanje.

Raščlambu svih razlika "slika u glavama" moglo bi se nastaviti u vrlo opširnoj formi i to poglavito temeljem dubrovačkoga pisma Matku Talovcu, kojega upravo zbog toga i donosim kao Prilog II. ovoj raspravi. No, ono od čega sam pošao i što me je prvenstveno zanimalo u ovoj prigodi jest samo jedna takva "slika u glavi", ona koja govori o tomu gdje je i kakvo je mjesto Bosne (Banovine, Kraljevstva) u sustavu koji sam označio kao Archiregnum Hungaricum. Sve što je dovde rečeno jasno potvrđuje da su sami Bošnjani vidjeli svoje Kraljevstvo, bez obzira na to u kojoj je mjeri eventualno bila razvijena svijest o njegovoj zasebnosti, kao dio političke zajednice kojom se vlada iz ugarskoga političkog središta, odnosno da su razumijevali kako ugarsko-hrvatski kralj ima određena prava i u njihovu Kraljevstvu. Takva je predodžba uključivala i samoga bosanskoga kralja, onoga istog koji je dinastičkim, nasljednim pravom bio "gospodar" Kraljevstva, kako se to dade razabrati već $\mathrm{i}$ iz spominjanoga naloga za ba- nove Ivana i Stjepana Frankopana. Sukladno sadržaju toga dokumenta (a na užas cjelokupne "patriotske" historiografije, koja vjerojatno zbog toga nikad taj dokument nije detaljnije ni pretresala $)^{163}$ prvi na popisu onih koji su trebali pružiti pomoć hrvatskim banovima u pohodu na Humsku zemlju (ne treba zaboraviti: u tome trenutku dio Bosanskoga Kraljevstva) bio je bosanski kralj, a odmah iza njega slijedio je njegov bosanski velikaš Juraj Vojsalić. Ovdje naravno nije od ključne važnosti to je li Tvrtko II. tako doista i postupio (za Jurja Vojsalića je to prilično uvjerljivo dokazano), nego to što se takva mogućnost uopće mogla koncipirati na Sigismundovu dvoru, a što opet savršeno precizno ocrtava "sliku u glavama" o tome odnosu, barem što se tiče političkoga (kraljevskoga) središta. Konačnu potvrdu da se tako stvari razumijevalo i na bosanskoj strani tvori kratki posjet kralja Tvrtka II. Tvrtkovića kralju Sigismundu krajem 1435. i početkom 1436 . godine. ${ }^{164}$

Ostavljajući po strani okolnosti i političko značenje Tvrtkova kratkotrajnog boravka na dvoru cara i kralja Sigismunda, ovdje u prvi plan stavljam

detaljno dalo raščlaniti ponašanje dubrovačkih vlasti spram Matkova izaslanika Jurja Chera, no već i ovo što je rečeno dostatan je argument za iznesene zaključke.

163 Indikativan je u tome smislu primjer S. Ćirkovića, koji registrira nalog bez ikakva spomena osoba koje su banovima u tome trebale pružiti subsidia et auxilia, ali dodaje kriptičnu opasku prema kojoj je u Sigismundovu planu djelovanja protiv vojvode Stipana kralju Tvrtku II. "svakako bila namenjena uloga", što jasno potvrđuje da je nalog ipak čitao - vidi: S. Ćirković, Herceg Stefan..., str. 8 i bilj. 9.

164 Sve što se u literaturi ranije znalo o tome posjetu sabrao je D. Lovrenović, Na klizištu povijesti..., str. 273-276. U novije vrijeme, međutim, spoznaje o tomu obogaćene su "otkrićem" dvaju neobjavljenih dokumenata na kojima svoje raščlambe temelje SRĐAN Rudić, "Nekoliko novih podataka o Restoju Milohni", u: Istorijski časopis, 58, Beograd, 2009., str. 173-180, te Neven IsAilović, "Nekoliko novih podataka iz 1436. godine o familijarima Hrvatinića u župama Zemunik i Glaž", u: Istorijski časopis, 60, Beograd, 2011., str. 154-177. 
dva privilegija što ih je za toga kratkoga posjeta izdala Sigismundova kraljevska kancelarija članovima Tvrtkove pratnje. Jedan od tih privilegija izdan je tadašnjem Tvrtkovom komorniku, u historiografiji dobro poznatom Restoju sinu Milohne pod nadnevkom 18. siječnja 1436. i predstavlja zapravo potvrdnicu za Restojeve posjede, kako one nasljedne, tako i one koje je kao nadarbinu dobio od svoga "gospodara", kralja Tvrtka II. Tvrtkovića. ${ }^{165}$ Drugi dokument, privilegij, ispostavila je Sigismundova kancelarija pod nadnevkom 20. siječnja 1436. na ime stanovitoga Milivoja Kresovog, zvanog Mačić, iz Gernice i njegove braće, odnosno njegovih srodnika, a i on predstavlja potvrdnicu darovnice što ju je Milivoju i njegovim srodnicima svojedobno izdao donjokrajski vojvoda Juraj Vojsalić od Sokola, nećak i stvarni nasljednik čuvenoga splitskog hercega i donjokrajskoga kneza Hrvoja Vukčića Hrvatinića. ${ }^{166}$

Teško je uopće precijeniti značenje ovih dvaju dokumenata iz perspektive ocrtavanja misaonih shema kojima su bili uređeni status Bosanskoga Kraljevstva i njegova kralja kao i njihovi odnosi s ugarsko-hrvatskim kraljem. Pri tome valja u prvome redu naglasiti da je već i čin izdavanja ovih potvrdnica teško zamisliti bez intervencije samoga bosanskog kralja, koji je kraljevsku "milost" (gracia) ugarsko-hrvatskoga kralja u obliku potvrdnice tražio za svoje vlastite podanike, i to one koji su bili u njegovoj pratnji. Svi posjedi koji se potvrđuju pripadnicima Tvrtkove pratnje bili su na području vladanja bosanskoga kralja, u Bosanskome Kraljevstvu, a ugarsko-hrvatski kralj, u slučaju Restoja Milohne navodi i izrijekom da je Restoje služeći svome kralju služio "uzvišenju našem i krune našega Kraljevstva Ugarske" (celsitudini nostre coroneque regni nostri Hungarie) te njemu i njegovu potomstvu ostavlja punu slobodu služenja bosanskome kralju, ali i bilo kojem drugom vjernom podaniku ugarsko-hrvatskih kraljeva (tribuimus atque damus facultatem vt ipsi temporibus semper successiuis vniuersis regibus dicti regni nostri Bosne pro tempore constitutis seu aliis nobis nostrisque successoribus regibus ac sacre corone et regno nostris Hungarie fidelibus et obedientibus libere et secure seruire et famulari valeant atque possint). No, i ovo valja posebice naglasiti: kancelarija je dokumente izdala dakako sukladno volji samoga kralja, ali je osoba koja je tu volju prenijela i praktično izdala nalog za sastavljanje privilegija (to je značenje primjedbe Relatio, koja se uobičajeno stavljala iznad ili ispod teksta samoga dokumenta, a koja je unesena u oba privilegija) bio Matko Talovac, tadašnji ban Slovinja. Formalno to očito nije mogao uraditi bosanski kralj. S druge strane, privilegiji za Restoja i Milivoja tvore pozadinu na kojoj posve razumljivim i jasnim postaju brojni izričaji u sačuvanome fondu dokumenata 15. stoljeća koji su na određeni

165 Dokument, koji se u Mađarskom državnom arhivu čuva pod signaturom MOL DL 44077, prepričava S. Rudić, "Nekoliko novih podataka...", no kako su neka mjesta loše pročitana, a iz prepričavanja nije vidljiva ni cjelina, pa onda ni pravo značenje dokumenta, donosim ga ovdje u transkripciji kao Prilog I.

166 Dokument u cjelini donosi N. Isailović, "Nekoliko novih podataka...", str. 174-175. 
način mogli i jesu izazivali dvojbe u historiografiji. Za ilustraciju ću uzeti samo slučaj vojvode Sandalja, koji je u onome ovdje već spominjanom dokumentu o ustupanju Konavala objašnjavao narav svojih prava na svoje "plemenito" (kojega dio odstupa Dubrovniku). To njegovo "plemenito" bilo mu je "dan'no i zapisanno" po kralju i cijelom rusagu bosanskom, od istih potvrđeno, ali je i "od kralev' ugrscih' i car' tur's'cih' potvr'evano po nih' krasnih' listih'". ${ }^{167}$ Upravo na te "krasne liste" se vjerojatno oslanjao Sandaljev nećak i nasljednik, budući herceg, Stipan Vukčić Kosača prije no što je počeo otvoreni sukob oko Humske zemlje (o kojem je ovdje već bilo riječi), kada je tražio jednoga dubrovačkog plemića koji bi s "njegovim poveljama" nastupao pred kraljem. Konačno, "milosti i privilegije" (gratias et privilegia) što ih je Sigismund podijelio Sandalju, a u kojima su i poimenično (poput privilegija što ih je izdala Sigismundova kancelarija 18. i 20. siječnja 1436. Restoju i Milivoju) bili navedeni posjedi, spominju se i u potvrdnici Stipanovih posjeda što ju je ishodio od njemačkoga kralja i budućega cara Svetoga Rimskog Carstva, Fridrika Habsburškoga. ${ }^{168}$

Teško bi, pa i praktično nemoguće, bilo braniti stajalište kako su, barem u prvim desetljećima 15. stoljeća, potvrdnice posjeda bosanskoga plemstva što su ih izdavali ugarsko-hrvatski kraljevi imale isto značenje i istu težinu kao sultanove potvrdnice za iste posjede, kako to proizlazi iz ovdje prenesenoga teksta Sandaljeva privilegija iz 1419. godine i kako stvari, temeljem ovoga izričaja, tumači primjerice E. Kurtović. ${ }^{169}$ Prva bi poteškoća pri tomu bila ta da se, zasad, ne zna za izdavanje takvih potvrdnica prije vladavine kralja Sigismunda, što automatski otvara pitanje kako su se i zašto uopće počeli izdavati takvi formalni dokumenti? (Isti slijed pitanja bi valjalo postaviti i za sultanove potvrdnice, no posve sam siguran da bi se odgovori uvelike razlikovali). Odgovor bi na to pitanje, čini se, trebao ići tragom pojave dvaju kraljeva, odnosno pretendenata na krunu sv. Stjepana, Sigismunda Luksemburškoga i Ladislava Napuljskog. U sličnoj situaciji krajem 13. stoljeća, kada je (također iz Napulja) Andriji III. bilo osporeno pravo na krunu sv. Stjepana i kada su pretenzije na tu krunu malodobnoga Karla Roberta već postale ozbiljne, počele su s napuljskoga dvora dolaziti darovnice za nove i potvrdnice za stare (ili uzurpirane) posjede svima koji bi iskazali spremnost priznati Karla za kralja. Upravo u tim okolnostima uslijedila je i prva poznata potvrdnica posjeda u tada Bosanskoj Banovini izdana od (tada doduše i tehnički još neokrunjenoga) ugarsko-hrvatskoga kralja. Bila je to potvrdnica posjeda donjokrajskoga kneza Hrvatina i nje-

167 Lj. Stojanović, Stare srpske povelje..., I., str. 293, br. 314, 24. 6. 1419.

168 Izvadak iz Fridrikove potvrdnice, izdane 20. siječnja 1448., u kojem se navode omnes et singulares gratias et privilegia - olim patruo suo Sandal per dive memorie Sigismundum imperatorem, necnon regem Ungarie etc concessas et concessa ... in quibus infrascripta castra forent conprehensa donosi E. KurTOvić, Veliki vojvoda..., str. 231, bilj. 824.

169 E. Kurtović, Veliki vojvoda..., str. 230-231. 
govih srodnika, izdana na intervenciju tadašnjega bana Hrvata, Pavla Šubića Bribirskoga. ${ }^{170}$

Nepuno stoljeće kasnije, 1391. godine, opet će Hrvatinići biti prvi među bosanskim plemićima (no sada već i bez posrednika) koji će od također neokrunjenoga (dakle, tehnički od još uvijek pretendenta, i k tomu malodobnoga) ugarsko-hrvatskoga kralja iz Napulja tražiti i dobiti darovnice/ potvrdnice za posjede koje su ionako već držali u svojim rukama. ${ }^{171} \mathrm{U}$ kasnijim vremenima izdavat će kralj Ladislav privilegije i potvrdnice svojim pristašama gotovo bi se moglo reći "na tekućoj traci", pa valja pretpostaviti da je upravo to natjeralo i Sigismunda, koji je ipak kontrolirao veći dio Ugarsko-Hrvatskoga Kraljevstva, da i sam prihvati tu praksu, kako se to dade razabrati iz ovdje navedenih primjera. Upravo u takvu svjetlu valja dakle sagledati i ideju bosanskih plemića iz 1406. da zatraže u Napulju potvrdu svojih "starih običaja i prava".

Spominjanje, pak, "granica" u potvrdnici iz 1406. godine, ali i Sigismundova ideja o "popravljanju i obnovi" granica prema Bosanskom Kraljevstvu, trebalo bi, barem ako je suditi po sadržaju zasad poznatih vrela, vezati u prvome redu upravo uz djelovanje braće Vukčića Hrvatinića. Oni su zapravo narušili dotadašnje stanje i "granice" koje su dotad bile uredene sukladno tradiciji. Hrvoje i Vuk su, kako je rečeno, posebnom darovnicom dobili dalmatinsko-hrvatski banat, no izgleda da je Vuk već i prije toga dobio čast dalmatinsko-hrvatskoga bana, po svemu sudeći od kralja Tvrtka I. ${ }^{172}$ Banska je čast bila officium koji se odnosio na određeni, iako ne precizno ograničeni teritorij, a darivanje banata (ne čak ni banske časti) u vlasništvo uvelike je narušavalo to načelo. $S$ druge strane, njihov brat Dragiša dobio je, onom darovnicom od 17. srpnja 1391., varoš Sridu u sanskoj županiji, koja je tada pripadala Hrvatskome Kraljevstvu, ali i selo Zabich u okolici Ključa, u Bosanskome Kraljevstvu. Još jasnije narušavanje granica u kojima je funkcionirala državna administracija Ugarsko-Hrvatskoga Kraljevstva uslijedilo je 1403. godine, kad je aktom također Ladislava Napuljskog Hrvoje postao "Splitski herceg". Valja uz ovo svakako pripomenuti kako je Hrvoje imao neke vrsti "prekograničnoga" iskustva još iz vremena vlasti kralja Ludovika i relativno uređenih prilika.

170 Dokument je u skraćenoj formi regesta, u kojem se ipak, iako prilično nerazgovjetno, navodi kako se Hrvatinovi posjedi u Donjim Krajima nalaze u "zemlji Bosni" (partes provinciarum inferiores terre Boczinensis), tiskan je u: DZ, VII., str. 342-343, br. 295.

171 Braća Hrvoje i Vuk Vukčići Hrvatinići poslali su u ljeto 1391. kao svoga izaslanika u Napulj Ladislava Crniljevića iz Sane, pa su ovome 17. srpnja u Napulju izdana čak tri privilegija (DZ, XVII,, str. 372-377, br. 272, 273 i 274). Jednim privilegijem je braći darivan cijeli dalmatinsko-hrvatski banat, drugim privilegijem je sam Ladislav dobio posjed u vukovskoj županiji, a trećim privilegijem je trećem bratu, Dragiši Vukčiću Hrvatiniću darivana varoš Srida u sanskoj županiji te selo Zabich, koje se vodilo kao pripadnost ključke utvrde.

172 Usp. nalog što ga je kao regnorum Dalmacie et Crouacie banus izdao 16. travnja 1391., dostupan sada prema izdanju u: Mladen Ančić (prir.), Registra Splitskoga kaptola. Registri Zadarskoga i Splitskog kaptola, V: Fontes. Izvori za hrvatsku povijest, 20, Zagreb, 2014., str. 144, br. 38a. Darovnica Ladislava Napuljskoga uslijedila je tek tri mjeseca kasnije. 
Svoju dugu političku karijeru započeo je 1376. godine kao "vjerni kraljevski vitez" (fidelis miles noster) na Ludovikovu dvoru, ${ }^{173}$ njegovi bliski rođaci ne mnogo prije toga postali su slavonski plemići $s$ velikim vlastelinstvima u Dobroj Kući i Bršljanovcu koje su dobili u zamjenu za svoja vlastelinstva u Bosanskoj Banovini od kralja Ludovika, a sam je vrlo brzo postao "veliki bosanski vojvoda". U okolnostima, pak, stabilne kraljevske vlasti sve to izgleda nije predstavljalo problem, naprotiv. No, kad je pravo na krunu sv. Stjepana, nakon smrti kralja Ludovika 1382. godine i ubojstva Karla Dračkog 1386. godine, postalo predmetom prijepora, Hrvojevo "poigravanje" s "granicama" postalo je sporno i opasno, barem iz perspektive kralja Sigismunda, jer je iz te pozicije omogućavalo kontrolu širokoga prostora $\mathrm{u}$ zaleđu istočnojadranske obale te samim time širom otvaralo vrata pretendentu iz Napulja i posve destabiliziralo njegovu poziciju u političkom središtu. Stoga i Sigismundovu zamisao o "popravljanju i obnovi granica" valja promatrati u tome kontekstu, pri čemu bi svakako trebalo voditi računa i o onome što je ranije rečeno o promjeni percepcije prostora i usvajanju dvodimenzionalne slike toga prostora na podlozi kartografskoga znanja kakvo je demonstrirano u slučaju izrade zemljovida za Pipa Scolarija i kakvo je demonstrirano na kraljevskome dvoru 30-ih godina 15 . stoljeća u projektima za uređenje obrambenoga sustava protiv otomanskoga sultana.
Sigismundove intervencije u uređenje teritorijalno-administrativnih pitanja nisu se pri tome ograničavale na pitanje "granice" prema Bosanskome Kraljevstvu. On je, naime, precizirao i u pisanoj formi definirao i administrativne granice između banovina (regna) Slovinja i Dalmacije-Hrvatske, ${ }^{174}$ pa je posve jasno temeljem svega toga da "granice" o kojima je ovdje riječ on nije vidio kao "državne granice". Da su stvari doista stajale upravo tako ponajbolje se potvrđuje činjenicom da Sigismundu, nakon što je 1409. godine definitivno "iz slike" izbačen Ladislar Napuljski, čime je i Bosna izgubila značenje ključne uporišne točke oporbe njegovoj vlasti, više nije smetalo ni Hrvojevo "splitsko herceštvo", ni status regni Bozne, pa čak ni stvarno širenje teritorija Bosanskoga Kraljevstva na račun Hrvatskoga, odnosno Ugarsko-Hrvatskoga Kraljevstva, čega je bio savršeno dobro svjestan. Posve se to jasno zrcali i u slučaju izdavanja potvrdnice posjeda Restoju, njegovu bratu Medoju i njihovu rođaku Nikoli, čija se važnost vidi i na toj razini. Kad je, naime, odlučio doista izdati tu potvrdnicu, Sigismund je dobro znao da je županija (districtus) Livno s gradom Bistricom, gdje su se nalazili nasljedni posjedi Restoja, Medoja i Nikole, ranije pripadala "kraljevini" (regnum kao područje upravljanja) Hrvatskoj. $\mathrm{Ta}$ je informacija predstavljala dio fonda znanja kojim se raspolagalo na kraljevskome dvoru, pa je i eksplicirana u projektu kraljevskoga dekreta

173 Kao takav se spominje u dokumentu što ga je 21. lipnja 1376. izdala kancelarija kralja Ludovika u kontekstu iz kojega jasno proizlazi da je doista boravio na kraljevskome dvoru - vidi: M. AnčIć, Registar Splitskoga kaptola..., str. 76-77, br. 16a.

174 Usp. M. Ančić, "Dva teksta...", str. 182. 
kojim je trebalo urediti sustav obrane 1432. ili 1433. godine, a koji nikad nije dobio konačnu službenu formu te je ostao sačuvan samo u kasnijim prijepisima. ${ }^{175} \mathrm{U}$ tome tekstu između ostaloga stoji i ovo:

"Zna naime gospodin palatin Nikola de Gara, kao i mnogi drugi, da su zemlje i provincije (županije) kao što su Humska zemlja, Livno, Bistrica i druge, koje sada kao okupirane drže kralj Bosne i Bošnjani, pripadale gospodinu kralju Ludoviku i bile držane po banu kraljevine Hrvatske. Zna također gospodin palatin, kao i mnogi drugi, kako su utvrdu Greben i okolne utvrde sa svojim pripadnostima u vrijeme pokojnoga gospodina kralja Ludovika držali Ugri. Znaju također kako je (područje) bosanske biskupije, čiji biskup sada rezidira u Đakovu, preko Save i kako ga sada, zajedno s posjedima (biskupije) drže Bošnjani ... (potom se dalje nabrajaju i druge zemlje $i$ 'kraljevine' koje su nekad pripadale pod 'krunu' Ugarskoga Kraljevstva) ... Glede svega ovoga želi kraljevsko veličanstvo očitovanje gospode prelata i baruna i ostalih stanovnika Kraljevstva hoće li se iskazati voljnima inkorporirati rečene kraljevine Ugarskome Kraljevstvu, podrazumijeva se uključiti ih i držati unutar granica istoga. ${ }^{176}$
Unatoč dakle svemu ovome što se "znalo" u očito širokome dvorskom krugu pristao je Sigismund potvrditi Restojeve posjede u Livnu, pri čemu je u samome dokumentu i eksplicitno izrečena misao kako je livanjska županija "u krajevima Bosne" (in districtu Hlywno in partibus Bosne), i legalizirati sve darovnice i druge privilegije koje su u međuvremenu izdali bosanski kraljevi. U tome kontekstu valja promatrati i ponašanje kralja Tvrtka II. - tražeći i dobivajući potvrdnicu posjeda za svoga komornika, čime je priznavao nadvlast ugarsko-hrvatskoga kralja, bosanski je kralj međutim posredno dobio i potvrdu svoga prava na livanjsku županiju. No, čita li se privilegij pozornije primijetit će se da su ipak ostavljena barem "odškrinuta vrata" za naknadne intervencije kroz izričaj da je Restoju, Medoju, Nikoli i njihovim nasljednicima ostavljena sloboda birati hoće li služiti bosanskome kralju ili kojemu drugom kraljevskome službeniku ili plemiću.

Nije ovdje zbog ograničenja prostora moguće detaljnije razglabati način na koji je Livno postupno inkorporirano u Bosansko Kraljevstvo, no

175 Tekst nikada usvojenoga i odobrenog dekreta, nastalog po svemu sudeći između studenoga 1432. i siječnja 1433. tiskan je, s uvodnim komentarom, u: F. Döry et al. (prir.), Decreta Regni..., str. 405-424.

176 F. Döry et al. (prir.), Decreta Regni..., str. 416-417: Scite enim dominus Nicolaus de Gara palatinus et quamplures alii, quod terre et provincie, ut sunt Halomfeold, Hlewna, Berzezthel et alie, que nunc occupate tenentur per regem Bozne, et Boznenses ipsi predicto domino regi Ludouico tenebantur et possidebantur per banum regni Croatie. Scit etiam dominus palatinus et quamplures alii, qualiter castrum greben et alia castra ibi circumquaque existentia cum suis pertinentiis tempore dicti quondam domini regis Ludouici tenta fuerunt per Hungaros. Item sciunt quod ecclesia Boznensis, cuius episcopus nunc in Dyak residet, est ultra Zavum, que similiter nunc cum suis terris a Boznensibus possidetur ... His igitur respectibus maiestas regia per prelatos et barones ac regnicolas regni se vult declarare, utrum iidem dicant et velint esse dicta regna incorporata fore regno Hungarie, intelligantque includi ac existere sub metis eiusdem. 
ono bosansko pozivanje na "granice" iz vremena bana Kulina, što je i ušlo u potvrdnicu sastavljenu u kraljevskoj kancelariji u Napulju 1406. godine, posve izvjesno nije bilo iskaz želje za "uređenjem" ili "održanjem" neke "državne granice". Riječ je tu bila zapravo o upravo obrnutoj stvari, pri čemu je poziv na "starinu" bio tek dio strategija kakvima je širen teritorij pod vlašću bosanskih vladara, a što je bilo moguće ponajprije stoga što je u svijesti suvremenika ono što se nazivalo Bosna ipak trajno bilo uključeno u široki okvir dinastičke (nad)države pod krunom sv. Stjepana (dakle, priznanje nadvlasti otvaralo je mogućnost širenja teritorija na kojem se vlast stvarno i praktično ostvarivala). U tim okolnostima bosanski je kralj mogao biti doživljen kao jedan od velikaša te dinastičke (nad)države, upravo onako kako je to u svojoj oporuci, od koje sam ovdje i pošao, učinio Ivaniš Blagajski, stavljajući ga u isti niz s "knezovima Celjskim", "Lovrom palatinom" i "banom Matkom", a da pri tomu u formalnome smislu nije doista imao takav status, kako se to jasno vidjelo već i na primjeru izdavanja naloga kraljevskoj kancelariji za sastavljanje privilegija Restoju sina Milhne i Milivoju Mačiću (taj je nalog, kako je rečeno, izdao ban Matko Talovac, iako je posve izvjesno da je inicijativa potekla od bosanskoga kralja u čijoj su pratnji bili i Restoje i Milivoj).

Što je dakle pokazala ovdje predočena raščlamba? Uvjeren sam da je ta raščlamba učvrstila stajalište koje sam branio $\mathrm{u}$ ranijim prigodama, a prema kojemu je "Bosna", bez obzira radilo se o onoj "zemlji" iz 12. stoljeća između rijeka Bosne i Drine, o dinastičkoj banovini 13. i 14. stoljeća, kao konglomeratu starih "zemalja" pod vlašću potomaka (stvarnoga ili legendarnoga) "Kotromana Gota", ili o Kraljevstvu oblikovanom nakon 1377. godine, trajno ostala dio velikoga političkog sustava, dinastičke (nad)države za koju smatram kako ju je najzgodnije nazivati Archiregnum Hungaricum. U tome sustavu "Bosna" se razvijala u doista zasebni politički organizam, čiji su vladari i velikaši uspješnim strategijama, a zahvaljujući poglavito položaju zasebnosti unutar dinastičke (nad)države, uspijevali širiti teritorij pod svojim nadzorom i vlašću. Pri tomu su "žrtve" postale lokalne tradicije starih "zemalja" (poglavito u planinskome pojasu istočnojadranskoga zaleđa, gdje se prilike kontroliralo a onda i vladalo na poseban način) koje su se, negdje brže, negdje sporije, utapale u onaj jedinstveni politički organizam obilježen u prvome redu vlašću dinastije Kotromanića. Zbog nedostatnih vrela (riječ je tu kako o malome broju, tako i o njihovoj naravi) nemoguće je razabrati kako je tekao razvoj predodžbi a s njima i svijesti o "državnoj zasebnosti" dinastičke države, no posve je izvjesno da se taj razvoj poprilično razlikovao od razvoja već u najbližem susjedstvu, ponajprije zbog razlika u formi i širini društvene strukture. U tome smislu, zaprjeka razvoju takvih predodžbi posve je izvjesno bila nedostatak uređene Crkve, čiji su pripadnici drugdje dali neprocjenjiv doprinos razvoju teorije vlasti i stvaranju "slika u glavi" o njezinoj naravi i uređenju društva. 


\section{From land to kingdom}

\section{Position of Bosnia within the structure of Archiregnum}

\section{Summary}

The author discusses the complex problem of primarily political relations between Bosnia (the Bosnian Banate, later on the Bosnian Kingdom) and Hungary (the Hungarian-Croatian Kingdom). Prior to explaining his own view, the author criticizes the work of Dubravko Lovrenovic, taking it as an example of approach to the historical analysis of a school developed during the 20th century and provisionally called "the Belgrade-Sarajevo school". In the second part of paper the author, referring to the concept of Archiregnum Hungaricum, defined as "dynastic (super) state", analyzes oldest written records that shed light on the relations of the Hungarian-Croatian kings with Bosnia. In that regard, he tries to define the concept of "land" (terra, Land) calling upon the ideas of Otto Brunner and using them as tool in the analysis of relevant sources from the 12th and 13th centuries. Based on this analysis the author draws conclusions about transformation of the Bosnian Banate in the framework of dynastic (super) state, seeing it as a conglomerate of "lands" ruled by the Kotromanic dynasty, otherwise descendants of certain "Kotroman Got" who was installed as 'ban' by the intervention of the royal authority in the late 12 th or early 13 th century.

The author accepts the view that the "land" Rama, which was present in the style of Hungarian-Croatian kings from the 30s of the 12th century, was not the same as "land" Bosnia of that time. Consequently, equation of those geo-political terms happened only at the beginning of the 15th century due to the fact that the central authority managed to largely integrate the old "lands" and abolish their political independence. In the third part of the paper the author analyzes how this complex system worked in the 15th century using the data that concern the course of events from 1435 and 1436 . He uses the example of (unsuccessful) attempt of the Emperor and King Sigismund to organize a system of defense against the Turks on his western flank (from Bosnia to Albania). The relationship between the political center and periphery is portrayed through (unsuccessful) appropriation of the old principality of Hum (already integrated into the political framework of Bosnian Kingdom). At the same time the author tries to pinpoint mental pictures regarding "constitutional order" of Archiregnum based on the 
historical experience as well as trying to discern how they have influenced the practical actions of actors. In that vein he also warns that various ways of interpreting experience with differences in thought schemes derived through those processes was one of the main reasons for the failure of the planned venture. However the acceptance of the main schemata defining position of Bosnian Kingdom in the political framework of Archiregnum is illustrated through the analysis of the short visit of Bosnian King Tvrtko II to the Hungarian court at the beginning of 1436. In conclusion the author defines the Bosnian king as hereditary official of the royal apparatus of government who, apart from fulfillment of certain obligations to the political centre (many of which had a ritual dimension), really ruled autonomous political formation - the Bosnian Kingdom. Acceptance of such a position on the part of Bosnian rulers resulted in the possibility of constant expansion of the territory under the practical rule of the Bosnian king.

Keywords: Bosnia, the Hungarian-Croatian Kingdom, dynastic state, political concepts. 
Prilog I. ${ }^{177}$

19. ožujka 1435., Požun.

Matko Talovac, kovinski župan i gubernator zagrebackke biskupije, traži od svoga kaštelana u Velikom Kalniku da bezodvlačno uvede predstavnika zagrebačkoga kaptola u vlasništvo palače u utvrdi i njezinih pripadnosti.

Mathko de Talloucz comes Couiniensis gubernator episcopatus Zagrabiensis etc. nobili viro Petro Horwath castellano nostro castri Kemlek vocati salutem cum dileccione. Liczet nos nuper tempore scziliczet illo quo in estate proxime preterita ad seruicia regalia nos in Boznam contuleramus conthoralemque nostram in ipso castro Kemlek relinqueramus permansuram homines honorabilis capituli ecclesie Zagrabiensis in eodem castro eotunc existentes per te ad tempus ex certa causa de eodem castro fecerimus sequestrare, tamen nos nolentes in hac parte ipsi capitulo aliquod preiudicium irrogare dileccioni tue firmissime precipimus et mandamus quatenus mox visis presentibus vlteriori nostro mandato superinde non expectato homines prefati capituli Zagrabiensis presentium ostensores in palacium et totam portionem ipsum capitulum in eodem castro concernentem intromittere debeas et aliud prout nostram indignacionem cupis euitare non facturus in premissis, presentes tandem post lecturam reddi iubemus exhibenti. Datum Posonii sabbato proximo ante festum sancti Benedicti abbatis et confessoris, anno domini millesimo quadrigentesimo tricesimo quinto. 
Prilog II. ${ }^{178}$

31. kolovoza 1435., Dubrovnik.

Dubrovačka općina detaljno izvješćuje Matka Talovca zašto je i kako pokušaj njegova zastupnika, Jurja Chera, da preuzme drijevski trg završio neuspjehom.

Domino Mateo de Talloueç

Magnifice et potens amice noster dilectissime de mense iullii proxime lapso a cursoribus nostris ab imperiali maiestate redeuntibus vestras recepimus litteras quibus nobis intimabatis prelibatam regiam maiestatem magnificiencie vestre commisisse regimen terre Halomfelde prouentuum regabilium sibi racione dominii prouenientium rogantes vt tributum in opido Driua exigi consuetum quod certis pactionibus a voiuoda Sandagl tenebamus et post eius mortem perceperamus vobis siue nomine vestro Georgio Cher homini magnificiencie vestre quem ad terram Halomfelde dirigebatis exhibere vellemus. Super qua re etiam patentes litteras ab imperiali maiestate pretacta tunc accepimus eiusdem effectus. Post quarum receptione litterarum distulit idem Georgius Cher Narentum venire vbi est gabella pro qua dictum tributum debetur, qui locus vt nouit magnificiencia vestra est burgum et non opidum, usque ad diem decimam septimam augusti presentis ad quem locum cum attigisset ad nos scripsit vt ad eum mitteremus vnum ex nostris cui referre possit aliqua nobis explicanda parte imperialis maiestatis et magnificiencie vestre, cui cum responsum nostris litteris daremus et vnum ex nostris ad eum mitteremus accidit quod aduentu Teucrorum in Bosnam ad peticionem voiuode Stipani nepotis Sandagl tota terra Halomfelde commota est dubitacione ne a Teucris invaderetur cuius causa ipse Georgius concipiens timorem inde celleri fuga se absentauit adeo quod responsales littere nostre nec nuntius quem ad eum mittebamus et qui eum secutus est illum attingere minime potuerunt. Cuius rei causa vt gestorum et sequutorum magnificienciam vestram informaremus has dare volumus significantes quod summo gaudio nobis est et complacenciam grandem accipimus quod imperialis maiestas huiusmodi regimen terre Halomfelde et prouentuum suorum et ea debitorum magnificiencie vestre comiserit ceu qui omni bono augmento et honore magnificiencie vestre amicissime et nobis valde dilecte meritis et benficiis suis in nos et patriam hanc suam et gaudemus et id ipsum optamus et eo pro bona parte participamus. Verum ut res ex serie innotescat auisamus quod adhuc viuente voiuoda Sandagl eam gabellam Narenti conduximus pro parte spectante dicto Sandagl pro quinque annis futuris inceptis in kalendis 
aprillis proxime preteriti cui Sandagl extunc quia sic pactum erat in principio anni solutionem fecimus de parte ipsius tributi sibi debiti et quia magnificiencie vestre perspectum est cuiusmodi homines sunt isti domini Bosignani et quam suspiciosi et quoniam aduersantes nobis et nostris ubi ullam causam contra nos inuenire et habere possunt optaremus ualde vt nos et nostros mercatores a damnis voiuode Stipani predicti qui successit dicto Sandagl in toto dominio et per cuius dominium et terras ipsi nostri mercatores vt nostis conuersationem et transitum habent perseuaremus que quod nobis et nostris contingerent scimus non esse bone mentis imperialis maiestatis nec magnificiencie vestre quod in re ipsius gabelle quandocumque ad eam leuandam de manibus nostris deueniri uellet ea animaduersione eoque modo et ordine eaque potencia ad id procederetur et deueniretur quod cunctis palam et notissimum esset nos compulsos esse eam derelinquere potencia et ipsa vi propria vestra, non propterea quod ullo pacto resistenciam ullam facere intendamus quoniam nec nostrum est dare nec illam tuttari ab impedire volentibus sed dumtaxat hoc dicimus ne videamur nos ultro et magis voluntate et fidelitate qua maiestati pretacte tenemur quam ulla vi uel compulsione reliquere ipsam. Quod si secus actum fuerit defugi (?) ${ }^{179}$ quin imputacionem et damna recipiamus a dicto voiuoda Stipano qui suspiciosus semper rem trahet ad deteriorem partem et tributum ipsius gabelle tocius temporis quinque annorum a nobis consequi volet et inde mercatores nostros penis et damnis afliget innuendo nos semper non coacte sed voluntarie gabellam dimisisse vt serenissimo domino nostro et maginificiencie vestre placeremus in qua re iteratis/partibus presentibus?/ exoramus si nos si res nostra publica vt fides et spes est cara est et nos ab imputacione et damnis seruare uultis ea diligencia et cautione quandocumque ad id deueniri voluerit agatur quibus et intencione vestre satisfactum sit et nos insontes habeamur et a nobis damna arceantur cautumque fiat nobis quod solucionem salis nostri quod extabit in gabella ex primis denariis gabelle accipiemus. Que ut eo modo et ordine fiant rogamus etiam atque exoramus, alia digna nota non emergunt preter que paulo ante aliis nostris magnificiencie vestre fecimus nota.

Rector et consilium etc. Ragusii die vltimo augusti 1435.

$179 \mathrm{Na}$ ovome mjestu na rubu lista je dopisano: non poterimus. 
Prilog III. ${ }^{180}$

18. siječnja 1436., Stolni Biograd.

Car Svetoga Rimskog Carstva, ugarsko-hrvatski i češki kralj Sigismund Luksemburški potvrduje komorniku bosanskoga kralja Turtka II. Turtkovića, Restoju sina Milohne, njegovu bratu Medoju i njihovu rodaku Nikoli, posjed utvrde Sberchyky te nasljedne posjede u livanjskoj županiji.

Relatio Matkonis de Talloucz

regni Sclauonie bani

Sigismundus dei gracia Romanorum imperator semper Augustus ac Hungarie, Bohemie, Dalmacie, Croacie etc. rex memorie commendamus tenore presencium significantes quibus expedit vniuersis quod nos attentis et consideratis fidelitatibus et fidelium seruiciorum preclaris meritis, virtuosis gestis et sinceris complacenciis fidelis nostri egregii Resteye(!) filii Mylohwe(!) de Bogouinagora camerarii illustris Stephani Twertk regis Bosne fidelis nostri dilecti per ipsum in comitiua et familiaritate eiusdem Stephani regis domini sui in nonnullis nostris et regnorum nostrorum ipsiusque regis Bosne domini sui agendis et expedicionibus presertimque contra seuissimos Turcos crucis Christi persecutores dictique regni nostri Bosne et fidelium incolarum eiusdem diros et infestissimos ac continuos inuasores aliosque nostros et dicti regni Bosne rebelles et infideles se opponendo cum omni fidelitatis constancia iuxta tocius sue facultatis exigenciam celsitudini nostre coroneque regni nostri Hungarie exhibitis et impensis ac in futurum fideliter exhibendis ca-

stellum Sberchyky appellatum in dicto regno nostro Bosne habitum cum omnibus et singulis suis pertinenciis et vtilitatibus quibuslibet, item possessiones Sobrystye, Buczinyryno, Saderdye et Sagoryczani vocatas in districtu Hlywno in partibus Bosne habitas in cuius et quorum dominio pacifico idem Restoye suos ac Medoye fratris carnalis et Nicolai consobrini suorum progenitores ab antiquo perstitisse et se ipsos persistere asserit eciam de presenti simulcum vniuersis suis vtilitatibus et pertinenciis quibuslibet, terris scilicet arabilibus cultis et incultis, agris, pratis, siluis, nemoribus, montibus, vallibus, vineis et vinearum promontoriis, aquis, fluuiis, aquarumque decursibus, molendinis et molendinorum locis et generaliter quarumlibet vtilitatum integritatibus quouis nominis vocabulo vocitatis ad idem castellum et possessiones prenotatas de iure spectantibus et pertinere debentibus sub suis veris metis et antiquis ex certa nostre maiestatis sciencia et animo deliberato prefatis Restoye filio Mylohne ac Medoye et Nicolao eorumque heredibus et 
posteritatibus vniuersis premissis sic vti superius maiestati nostre exposita sunt et narrata stantibus et se habentibus dedimus, donauimus et contulimus ymmo damus, donamus et conferimus iure perpetuo et irreuocabiliter possidendum, tenendum pariter et habendum nichilominusque ad eiusdem Restoye supplicacionis instanciam vniuersa et singula priuilegia iuraque et litteralia instrumenta necnon litteras quaslibet regum Bosne super quibuscumque castellis, fortaliciis, terris, tenutis, possessionibus et villis et generaliter quibuslibet bonis ipsius Restoye pro parte predecessorum suorum et per consequens eiusdem sub quibusuis formis et tenoribus confecta et emanata seu concessas quorum omnium et singulorum tenores, capitula, clausulas, continencias et articulos volumus et decernimus perinde et precise sufficienter hic habere pro expressis ac si eadem et eedem de verbo ad verbum essent presentibus inserta et inclusa quo ad omnes earundem tenores, clausulas et articulos eatenus quatenus ipsa rite et legittime concessa dinoscuntur rata, grata et accepta habentes pro prefatis Restoye ac Medoye et $\mathrm{Ni}$ colao eorumque heredibus vniuersis ex certa nostre maiestatis sciencia et animo deliberato prelatorumque et baronum nostrorum ad id acceden- te consilio prematuro in perpetuum valitura roboramus, ratificamus atque confirmamus presentis nostri priuilegii patrocinio mediante sine tamen preiudicio iuris alieni. Annuimus nichilominus et indulgemus eisdem Restoye, Medoye et Nicolao ipsorumque heredibus ac omnimodam tenore presencium tribiumus atque damus facultatem vt ipsi temporibus semper successiuis vniuersis regibus dicti regni nostri Bosne pro tempore constitutis seu aliis nobis nostrisque successoribus regibus ac sacre corone et regno nostris Hungarie fidelibus et obedientibus libere et secure seruire et famulari valeant atque possint. In cuius rei memoriam firmitatemque perpetuam presentes concessimus litteras nostras pendentis et autentici maioris noui dupplicis sigilli nostri quo vt rex Hungarie vtimur munimine roboratas. Datum in ciuitate nostra Albaregali per manus venerabilis domini Mathye de Gathalowcz prepositi ecclesie Quinqueecclesiensis aule nostre summi cancellarii fidelis nostri dilecti, feria quarta proxima ante festum beatorum Fabiani et Sebastiani martirum, anno domini millesimo quadrigentesimo tricesimo sexto, regnorum nostrorum anno Hungarie etc. quadragesimo nono, Romanorum vigesimo sexto, Bohemie sedecimo, imperii vero tercio. 
Prilog IV. ${ }^{181}$

23. svibnja 1442., Čazma.

Knez Ivaniš Blagajski sastavlja oporuku, ostavljajući odredeni dio svojih dobara pojedinim crkvenim institucijama i namirujući one koje je za života oštetio, dok svu svoju pokretnu i nepokretnu imovinu ostavlja ženi Doroteji i sinu Nikoli. Takoder imenuje poglavare svojim familijarima, a ženu i sina ostavlja na skrb bosanskome kralju, knezovima Celjskim, palatinu Lovri i banu Matku.

In nomine domini. Amen. Anno eiusdem millesimo quadringentesimo quadragesimo secundo ego Iohannes comes de Blagay eger corpore sanus tamen per omnia mente de bonis michi a deo collatis condo et facio tale testamentum; primo et principaliter recordor me multa dampna intulisse abbati Toplicensi pro eo pro eisdem dapnis si me in presenti infirmitate contingat mori vestimenta mea meliora de auro adornata et contexta subducta pellibus mardurinis, item eidem claustro lego vrcellas seu ampullas de argento fabricatas et deauratas cum duabus candelabris similiter de argento fabricatis simulcum campana argentea et deaurata, item in eodem claustro eligo michi sepulturam si in hac infirmitate me mori continget; item comitto consorti mee vt familiam meam in ipsorum statu per me disposito conseruet in nullo eosdem turbando sed pocius aput se tanquam fideles conseruando; item duabus ecclesiis sub Zrynio videliczet beate virginis et beati Stephani pro dapnis que eisdem intulo lego duas scutellas argenteas; item ecclesie in possessione Drascha similiter lego vnam scutellam argenteam; item si me continget mori in presenti infirmitate tunc omnes littere nobilibus dictis Ladihowychi sine pecuniis et absque aliquali solucione pecuniali reddantur et restituantur et in hoc conthoralis mea aliud non sit factura quia pro anima mea hoc facere curaui; item omnes possessiones super quibus non haberem litteras autenticas et firmissimas illis quorum fuerunt sine solucione pecuniali remittantur; item si alique pecunie decimales que concernunt prepositum Zagrabiensem super facta nostra sunt exposite eidem de pecuniis meis restituantur; item omnia bona mea mobilia et immobilia lego conthorali mee et Nicolao filio meo ad guebrnandum et possidendum et committo eidem conthorali mee et filio meo supradicto vt ipsi de bonis meis iam dictis pro alleuiacione anime mee sepe sepius elemosinas et exequias facere debeant et teneantur; item Ladislao Zalawych de Egidowcz familiari meo lego septem florenos auri et octoginta solidos quibus sibi pro vno equo suo et pro vno boue obligor; item conthoralem meam cum filiio meo supradicto co- 
mmitto tuicioni et protectioni dominorum regis Bozne, comitum Cilie, Laurencii palatini et Mathkonis bani; item committo vt Stephanus Kolbas, Ladislaus filius Zala, Nicolaus filius Bank, Martinus Aytych et Nicolaus Polasaych ac Lucas castellanus omnium familiarum meorum sint directores et omnes familiares mei ipsos au- diant et eisdem obediant. Hoc autem testamentum feci coram egregiis viris Stephano Biczkele, Hennyng magistro, Martino lectore, Thoma cantore Chasmensis ad hoc specialiter vocatis, sigillis meo proprio ac dicti Mathkonis bani consignatum. Datum Chasme feria quarta proxima post festum penthecostes, anno supradicto.

29. kolovoza 1464., Zagreb.

Zagrebački kaptol izdaje na zahtjev kneza Martina i njegove žene Doroteje, udovice kneza Ivaniša Blagajskoga, podnesen po svećeniku Jurju, župniku crkve sv. Nikole iz Jastrebarskoga, ovjereni prijepis oporuke kneza Ivaniša Blagajskog.

Nos capitulum ecclesie Zagrabiensis memorie commendamus per presentes quod honorabilis vir dominus Georgius plebanus ecclesie beati Nicolai in opido Iazthraberzka nominibus et in personis spectabilis et maginifici domini Martini de Frangapan Segnie, Vegle et Modrussie comitis ad domine Dorothea vocate relicte condam spectabilis et magnifici domini Iohannis comitis de Blagay nunc vero consortis dicti domini Martini comitis exhibuit et presentauit nobis quoddam testamnetum prelibati condam domini Iohannis comitis de Blagay alias domini et mariti prefate domine Dorothee comitisse quibusdam duobus sigillis ab extra sigillatum vti prima facie apparebat de quibus in fine eiusdem testamenti sit mencio specialis petens nos debita cum instancia vt tenorem huiusmodi testamenti de verbo ad verbum in transcripto litte- rarum nostrarum patencium prefato domino Martino et domine Dorothee conthorali eiusdem dare dignaremur iuris ipsorum ad cautelam, cuius tenor is est:

\section{(slijedi oporuka kneza Ivaniša Blagajskog)}

Nos igitur supplicacionibus prefati domini Georgii plebani nomine quorum supra ad nos porrectis annuimus prescriptum testamentum preallegati condam domini Iohannis comitis de verbo ad verbum sine diminucione et augmento presentibus litteris nostris patentis inseri, transsumi et transscribi sigilloque nostro consignari facientes prefato domino Martino comiti et domine Dorothee conthorali eiusdem duximus concedendum iuris ipsorum pro cautela. Datum in festo decollacionis beati Iohannis Baptiste, anno domini millesimo quadrigentesimo sexagesimo quarto. 